University of Rhode Island

DigitalCommons@URI

Open Access Master's Theses

2012

\title{
ASSESSMENT OF INUNDATION RISK FROM SEA LEVEL RISE AND STORM SURGE IN COASTAL NATIONAL PARKS
}

Angelica Murdukhayeva

University of Rhode Island, angelica.murdukhayeva@gmail.com

Follow this and additional works at: https://digitalcommons.uri.edu/theses

\section{Recommended Citation}

Murdukhayeva, Angelica, "ASSESSMENT OF INUNDATION RISK FROM SEA LEVEL RISE AND STORM SURGE IN COASTAL NATIONAL PARKS" (2012). Open Access Master's Theses. Paper 92.

https://digitalcommons.uri.edu/theses/92

This Thesis is brought to you for free and open access by DigitalCommons@URI. It has been accepted for inclusion in Open Access Master's Theses by an authorized administrator of DigitalCommons@URI. For more information, please contact digitalcommons-group@uri.edu. 
ASSESSMENT OF INUNDATION RISK FROM SEA LEVEL RISE AND STORM SURGE IN COASTAL NATIONAL PARKS

BY

ANGELICA MURDUKHAYEVA

A THESIS SUBMITTED IN PARTIAL FULFILLMENT OF THE REQUIREMENTS FOR THE DEGREE OF

MASTER OF SCIENCE

IN

ENVIRONMENTAL SCIENCE

UNIVERSITY OF RHODE ISLAND 
MASTER OF SCIENCE THESIS

OF

ANGELICA MURDUKHAYEVA

\section{APPROVED:}

Thesis Committee:

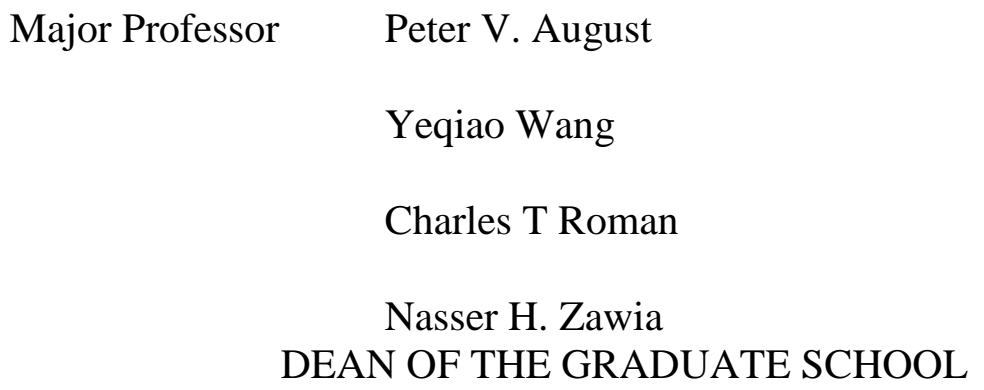




\begin{abstract}
In coastal ecosystems, sea level rise and an increase in storm frequency and intensity are two major impacts expected to result from climate change. Coastal National Parks have many low-lying areas that are at risk from inundation resulting from these impacts. In order to help park managers meet their goal of preserving valuable resources, I developed a methodology to evaluate risk of inundation from sea level rise and storm surge at sentinel sites, areas of importance for natural, cultural and infrastructural resources.

I performed a literature review on the factors driving sea level rise in the Northeast, and conducted an evaluation of the methods used by scientists and engineers to model sea level rise and storm surge inundation. I selected the most recent and appropriate geospatial tools, models and datasets to perform a coastal inundation risk assessment in three northeastern coastal National Parks-Boston Harbor Islands National Recreation Area, Cape Cod National Seashore, and Assateague Island National Seashore.

I collected elevation data at sentinel sites using real time kinematic global positioning system (RTK GPS) technology and assessed the accuracy of the most recent, readily-available Light Detection and Ranging (LiDAR) derived Digital Elevation Models. Because of the poor quality of existing LiDAR data, Boston Harbor Islands National Recreation Area was excluded from the final assessment. I evaluated risk of inundation at sentinel sites in Cape Cod and Assateague Island using three modeling approaches: bath-tub modeling, Sea Level Affecting Marshes Model (SLAMM), and Sea, Land and Overland Surges from Hurricanes (SLOSH) Model,
\end{abstract}


and developed an overall inundation index, a single measure of inundation likelihood that incorporated output from each modeling approach. I created inundation maps for a range of sea level rise and storm surge scenarios, calculated the probability of inundation at each sentinel site given the uncertainty associated with each model and dataset, and ranked the relative risk of sentinel sites to inform management and adaptation strategies. Cape Cod's sentinel sites, which in many cases occurred in high elevation settings, were found to be less vulnerable to inundation than Assateague Island's sentinel sites which were distributed in low-lying areas along the barrier beach island. This inundation risk assessment methodology can be applied to other coastal parks and to the same coastal parks at different times as more accurate elevation datasets and updated sea level rise projections become available. 


\section{ACKNOWLEDGMENTS}

I am eternally grateful to all of my mentors, teachers and friends on this journey. First and foremost, I thank my Major Professor, Peter August, for his mentorship, support and kindness in all matters, big and small. I thank my committee-YQ Wang, Charles Roman, and Howard Ginsberg—-for sharing their valuable time, knowledge and experience in this process. I thank Michael Bradley and Charles LaBash for their patient guidance and leadership.

I thank Nigel Shaw, who initiated this research endeavor and accepted me onto the team with kindness and graciousness, and Charles Roman, who insisted that a graduate student be involved in the project and made this experience possible for me. This research has benefited from the input of many passionate scientists and researchers: Tim Smith, Rob Thieler, Don Cahoon, Kelly Knee (Applied Science Associates), Neil Winn, Marc Albert, Mark Adams, Doug Marcy, and many others.

I thank my colleagues at the Environmental Data Center—Roland Duhaime, Dennis Skidds, Galen Scott, Chris Damon, Greg Bonynge, Aimee Mandeville, John Clark, Tiffany Davis, and Heather Grybas—whose presence, helpfulness and humor over the last two years have enriched my journey. I am grateful to the faculty, staff and students of the Natural Resources Science Department for cultivating a vibrant and supportive learning environment. I thank Deb Bourassa for her help and support.

This research was supported by National Park Service Task Agreement \#J4531090800 - "Assessing Inundation Risk From Sea Level Rise and Storm Surge in Coastal National Parks Using High Accuracy Geodetic Control." 


\section{PREFACE}

This thesis is organized in Manuscript Format as described by the URI Graduate School guidelines on thesis preparation. The body of the text corresponds to the journal article format specified by the Journal of Coastal Research. 


\section{TABLE OF CONTENTS}

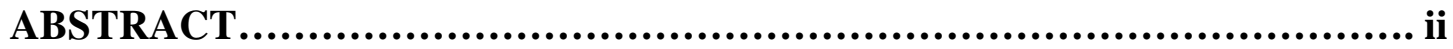

ACKNOWLEDGEMENTS ...................................................... iv

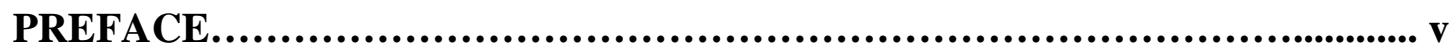

TABLE OF CONTENTS......................................................... vi

LIST OF FIGURES...........................................................

LIST OF TABLES.......................................................... ix

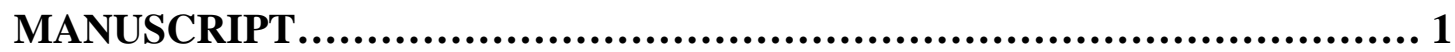

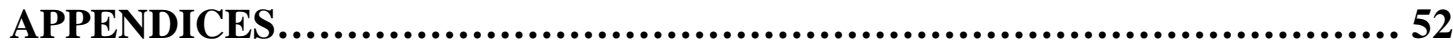




\section{LIST OF FIGURES}

FIGURE

PAGE

Figure 1. Regional map with locations of study areas............................22

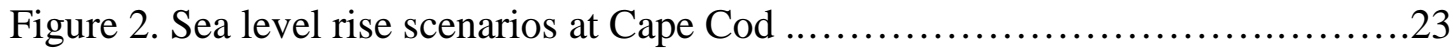

Figure 3. Sea level rise scenarios near Verrazano Bridge, Assateague Island..........24

Figure 4. Inundation expected from storm surges at Cape Cod......................25

Figure 5. Inundation expected from storm surges at Assateague Island................26

Figure 6. SLAMM initial conditions and model output at Assateague Island. ........ 27

Figure 7. SLAMM output at Assateague Island. Eleven possible land use classes in this study area aggregated into five broad groups for ease of interpretation...........28

Figure 8. Overall inundation index for sentinel sites at CACO.......................29

Figure 9. Overall inundation index for sentinel sites at ASIS ....................... 30

Figure 10. Sentinel site with low relative likelihood of inundation......................31

Figure 11. Low-lying sentinel site at Cape Cod National Seashore...................32

Figure A1.1 Mapping $1 \mathrm{~m}$ of sea level rise on land, adapted from Gesch (2009).....57

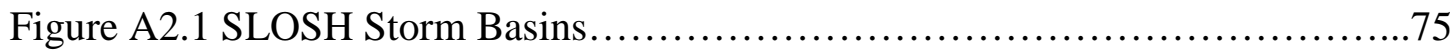

Figure A5.1 CACO Bath-tub modeling of $1 \mathrm{~m}$ sea level rise.........................92

Figure A5.2 CACO Bath-tub modeling of $2 \mathrm{~m}$ sea level rise........................93

Figure A5.3 ASIS Bath-tub modeling of $0.6 \mathrm{~m}$ sea level rise.......................94

Figure A5.4 ASIS Bath-tub modeling of $1 \mathrm{~m}$ sea level rise.........................95

Figure A5.5 ASIS Bath-tub modeling of $2 \mathrm{~m}$ sea level rise.........................96

Figure A5.6 CACO Category 1 Hurricane inundation predicted by SLOSH...........97

Figure A5.7 CACO Category 2 Hurricane inundation predicted by SLOSH...........98 
Figure A5.8 CACO Category 3 Hurricane inundation predicted by SLOSH...........99

Figure A5.9 CACO Category 4 Hurricane inundation predicted by SLOSH.........100

Figure A5.10 ASIS Category 1 Hurricane inundation predicted by SLOSH........101

Figure A5.11 ASIS Category 2 Hurricane inundation predicted by SLOSH.........102

Figure A5.12 ASIS Category 3 Hurricane inundation predicted by SLOSH.........103

Figure A5.13 ASIS Category 4 Hurricane inundation predicted by SLOSH.........104

Figure A5.14 CACO SLAMM Input: Initial conditions....................... 105

Figure A5.15 CACO SLAMM Output: $1 \mathrm{~m}$ sea level rise scenario.................106

Figure A5.16 CACO SLAMM Output: $2 \mathrm{~m}$ sea level rise scenario................107

Figure A5.17 ASIS SLAMM Input: Initial conditions..........................108

Figure A5.18 ASIS SLAMM Output: $0.6 \mathrm{~m}$ sea level rise scenario.................109

Figure A5.19 ASIS SLAMM Output: $1 \mathrm{~m}$ sea level rise scenario.................110

Figure A5.20 ASIS SLAMM Output: $2 \mathrm{~m}$ sea level rise scenario...................111

Figure A6.1 Relative Coastal Vulnerability for Cape Cod National Seashore, from

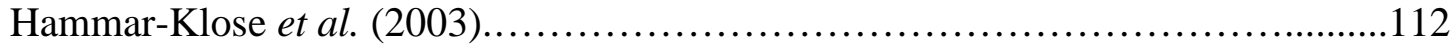

Figure A6.2 Relative Coastal Vulnerability for Assateague Island National

Seashore, from Pendleton, Williams, and Thieler (2004)......................113 


\section{LIST OF TABLES}

TABLE

PAGE

Table 1. List of data, tools and sources....................................... 33

Table 2. Summary of sentinel site elevations.................................... 34

Table 3. Summary of LiDAR vertical accuracy assessment..................... 35

Table 4. Storm surge heights predicted by SLOSH................................ 36

Table 5. Extent of inundation (in hectares) within each study area under bath-tub model sea level rise scenarios and SLOSH hurricane scenarios...................... 37

Table 6. Mean ( \pm SE) probabilities of inundation at sentinel sites given bath-tub modeling scenario. Shown in parentheses is the number of sites where the probability

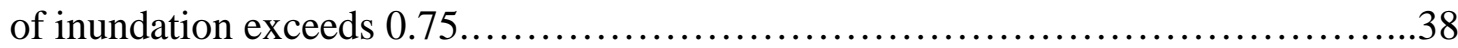

Table 7. Mean ( \pm SE) probabilities of inundation at sentinel sites using the SLOSH storm scenarios. Shown in parentheses is the number of sites where the probability of inundation exceeds 0.75

Table 8. CACO SLAMM conversion matrix................................... .40

Table 9. ASIS SLAMM conversion matrix..................................41

Table 10. CACO SLAMM conversion matrix with aggregated classes...............42

Table 11. ASIS SLAMM conversion matrix with aggregated classes..............43

Table 12. Principal components analysis of risk variables. Class loadings for the first three principal components are provided for each variable...................... 44

Table 13. Inundation Index class and corresponding PC1 raw scores. PC score classes were based on quintile categories of the data............................... 45

Table A1.1 Sea level trends measured at tide gauges near NPS study sites ..........58 
Table A1.2 Errors associated with orthometric-tidal datum conversions..............59

Table A3.1 Boston Harbor Islands (BOHA) sentinel site elevations..................80

Table A3.2 Cape Cod National Seashore (CACO) sentinel site elevations........... 81

Table A3.3 Assateague Island National Seashore (ASIS) sentinel site elevations.....84

Table A4.1 Probabilities of inundation and overall inundation index (PC1) at sentinel

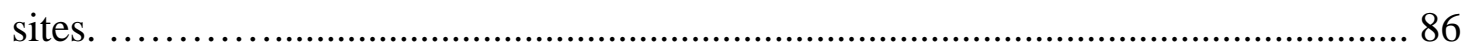




\title{
MANUSCRIPT
}

To be submitted for publication in the Journal of Coastal Research

\section{Assessment of Inundation Risk from Sea Level Rise and Storm \\ Surge in Coastal National Parks}

\author{
Angelica Murdukhayeva ${ }^{1}$, Peter August ${ }^{1}$, Michael Bradley ${ }^{1}$, Charles LaBash ${ }^{1}$, Nigel \\ Shaw $^{2}$ \\ ${ }^{1}$ Dept. of Natural Resources Science, University of Rhode Island, Kingston, RI, USA \\ ${ }^{2}$ National Park Service, Northeast Region, 15 State Street, Boston, MA, USA
}

Corresponding Author: Angelica Murdukhayeva

Natural Resources Science

University of Rhode Island

105 Coastal Institute

Kingston, RI, 02881, USA

Phone +1-401-874-5054

Email address: angelica@edc.uri.edu 


\section{INTRODUCTION}

In coastal ecosystems, accelerated sea level rise and an increase in storm frequency and intensity are two major impacts expected to result from climate change (Ashton, Donnelly, and Evans, 2008; Bender et al., 2010; Harvey and Nicholls, 2008). In the next century, the rate of global sea level rise is anticipated to be several times higher than measured over the past century (Cazenave and Nerem, 2004; Church and White, 2006; Overpeck and Weiss, 2009; Pfeffer, Harper, and O'Neel, 2008; Rahmstorf, 2007). The US Northeast coast experiences a rate of relative sea level rise greater than the global average due to substantial regional variations in glacial isostatic adjustment effects and oceanographic processes (Tamisiea and Mitrovica, 2011). Along the US Atlantic coast, the highest rates of subsidence occur from southern Massachusetts to Virginia (Engelhart, Peltier, and Horton, 2011) and predicted changes in ocean circulation driven by climate change could potentially add meters of dynamic sea level rise near the Northeast coast (Hu et al., 2009; Yin, Schlesinger, and Stouffer, 2009). The frequency and extent of severe coastal storms is expected to increase (Bender et al., 2010), and large surge levels may cause significant damage to coastal infrastructure and alteration of ecosystems (Irish et al., 2010; Kirshen et al., 2008; Lin et al., 2010; McInnes et al., 2003). A discussion of factors driving sea level rise in the region is provided in Appendix 1.

This investigation will assess inundation risk from sea level rise and storm surge at sentinel sites in three coastal, northeastern United States National ParksBoston Harbor Islands National Recreation Area, Cape Cod National Seashore, and Assateague Island National Seashore. Sentinel sites are locations of natural or cultural 
resources of special importance to the National Park Service. The term "at risk" is used to indicate that a sentinel site is predicted to be inundated as a result of sea level rise or storm surge. Some sites that are predicted to be at "at risk" are not necessarily threatened or impacted; natural features may be altered as a result of rising water levels yet persist because of their resilience to change. However, habitats, cultural, or infrastructural resources may be severely impacted if they are inundated. Thus, "risk" does not imply "impact" in my study. In either case, an understanding of the relative vulnerability of each sentinel site to inundation will allow park resource managers to develop management and mitigation strategies for these sites.

A variety of quantitative approaches have been used to assess the impact of sea level rise and storm surge on coastal inundation and flooding. Several hydrodynamic models are used to model inundation from rising sea levels, for example: MIKE 21 and MIKE FLOOD (Sto. Domingo et al., 2010), LISFLOOD-FP (Lewis et al., 2011) and ANUGA (Van Drie, Milevski, and Simon, 2010). The US Federal Emergency Management Agency (FEMA) relies on a Geographic Information Systems (GIS) model, HAZUS-MH, to estimate the physical, economic and social impacts of largescale flooding events (Scawthorn et al., 2006a; Scawthorn et al., 2006b). Other GISbased methods have been applied as well (Brown, 2006; Hennecke and Cowell, 2000). A review of sea level and storm surge inundation models is provided in Appendix 2.

Coarse-scale assessments for sea level rise and storm surge risk have been previously conducted. The Coastal Vulnerability Index (CVI) technique was applied at Cape Cod National Seashore (Hammar-Klose et al., 2003) and at Assateague Island National Seashore (Pendleton, Williams, and Thieler, 2004). The method combines a 
number of physical variables in order to classify the relative risk of $1.5 \mathrm{~km}$ shoreline segments to sea level rise impacts. Gutierrez, Williams, and Thieler (2007) studied potential shoreline changes from sea level rise along the U.S. Mid-Atlantic Coast. The CVI and shoreline change assessments were designed to provide a regional overview of coastal vulnerability and do not have the spatial resolution for site-specific risk assessment.

All vulnerability models and methods rely on elevation data, which are often highly limited in their vertical accuracy and cause large ranges of uncertainty in results (Gesch, 2009). The National Elevation Dataset (NED) is the largest scale, readily available topographic dataset for the country but with a vertical accuracy (RMSE, or root mean square error) of $2.44 \mathrm{~m}$ (Gesch, 2007) is of little value in assessing inundation risk at specific sites. My study relies on two sources of higher accuracy elevation data for sentinel sites: light detection and ranging (LiDAR) data and real time kinematic global positioning system (RTK GPS) data. My assessment integrates output for three sea level rise scenarios and four storm surge scenarios from several modeling approaches: bath-tub inundation modeling with tidal-orthometic datum conversion, application of the Sea Level Affecting Marshes Model (SLAMM), and application of the Sea, Land and Overland Surges from Hurricanes (SLOSH) model. The probabilities of inundation at sentinel sites are calculated for each modeled scenario and an index is developed to estimate overall inundation likelihood at a sentinel site. This overall index of inundation likelihood will be a valuable tool for prioritizing long-term management and climate change adaptation plans at sentinel sites in the National Parks. 


\section{METHODS}

\section{Study Areas}

I conducted analyses at three coastal parks (Figure 1): Boston Harbor Islands National Recreation Area (BOHA), Cape Cod National Seashore (CACO), and Assateague Island National Seashore (ASIS). BOHA is located in the Boston Harbor of Boston, Massachusetts, USA, contains 34 islands and peninsulas, and protects nationally significant cultural and natural resources, including military fortifications, cemeteries, lighthouses, coastal bird nesting sites, and rare plants. CACO is located on the outer portion of Cape Cod, Massachusetts, USA, encompasses $64 \mathrm{~km}$ of shoreline, and contains a variety of marine, estuarine, and terrestrial ecosystems. ASIS is located on the Delmarva Peninsula and lies within the boundaries of two states, Maryland and Virginia. It is a $60 \mathrm{~km}$ long, undeveloped barrier island that consists of large stretches of dunes, beaches and marshes. The three study areas represent a diversity of coastal ecosystem landscapes: a barrier island of the mid-Atlantic (ASIS), an extensive peninsula (CACO), and a rocky coast within the Gulf of Maine (BOHA). This provides different geomorphic conditions to test the models and methods used.

\section{Data Sources}

The study incorporates the most recent, readily-available elevation data and widely-used inundation mapping tools and techniques. Elevation measurements for inundation models were acquired from LiDAR data obtained from aircraft-mounted laser sensors that emit pulses of light energy at the ground and measure the distance based on the time required for the pulses to reflect back to the sensor. LiDAR data are typically accurate to $0.15-1 \mathrm{~m}$ (Gao, 2007). The U.S. Geological Survey (USGS) and 
the National Park Service (NPS) provided LiDAR-derived Digital Elevation Models (DEMs) for CACO and ASIS; and the Office of Geographic Information in the Commonwealth of Massachusetts Information Technology Division (MassGIS) provided a LiDAR-derived DEM for BOHA. I assessed the vertical accuracies of the DEMs using highly accurate ground control points.

Locations of sentinel sites were obtained from park resource managers and consisted of natural resources, cultural resources, and infrastructure of special importance to the parks. The locations and elevations of sentinel sites were fieldsurveyed using RTK GPS (Trimble R8 GNSS) in 2011 and 2012. RTK GPS provides data to within $5 \mathrm{~cm}$ vertical accuracy.

\section{Sea Level Rise Scenarios}

Three scenarios were selected to represent the current range of sea level rise predictions for the year 2100: $0.6 \mathrm{~m}$ (IPCC, 2007), $1 \mathrm{~m}$ (Vermeer and Rahmstorf, 2009), and 2 m (Pfeffer, Harper, and O'Neel, 2008). They were modeled using two methods. The first approach-the bath-tub model- involved creating a planar water surface that represents the sea level rise scenario added to the Mean Higher High Water (MHHW) tidal elevation. Modeling sea level rise or storm surge in addition to the MHHW level represents the worst case inundation scenario. These water surface elevations were calculated using VDatum software (NOAA, 2011), which performs elevation conversions between NAVD88 (an orthometric datum) and tidal datums. The land surface elevation and modeled water surface were compared and probabilities of inundation at sentinel sites were calculated using the z-score inundation uncertainty technique described by NOAA Coastal Services Center 
(2010a). Standard scores, or z-scores, were calculated at each sentinel site using the formula:

$$
\mathrm{Z} \text {-Score }=\frac{\text { Inundation Level }- \text { Elevation }}{R M S E_{\text {Total }}}
$$

Where the total RMSE (root mean square error) is calculated as:

$$
\mathrm{RMSE}_{\text {Total }}=\sqrt{{\text { RMSE } E_{\text {Elevation }}{ }^{2}+\text { RMSE }_{\text {WaterSurface }}}^{2}}
$$

RMSE for LiDAR DEMs is calculated as:

$$
\mathrm{RMSE}=\sqrt{\frac{\sum_{i=1}^{n}\left(x_{L i D A R, i}-x_{G P S, i}\right)^{2}}{n}}
$$

Where $\mathrm{X}_{\mathrm{LiDAR}}$ is the elevation from LiDAR at a single location and $\mathrm{X}_{\mathrm{GPS}}$ is the elevation as determined by GPS in the same location. RMSEs for the GPS survey elevations were reported by Trimble Software. RMSEs for water surfaces were reported by VDatum. The standard normal cumulative distribution function was used to calculate probabilities of inundation and the certainty of the prediction given errors associated with the data and models (Ott and Longnecker, 2010).

Two probabilities of inundation were calculated for each sentinel site: one using the elevation from the LiDAR-derived DEM, and the second using the elevation determined from the RTK GPS survey. The two methods used to measure elevation at sentinel sites - LiDAR-derived DEM and RTK GPS of the site - had very different vertical accuracies (RMSE values) and resulted in different estimates of the probability of inundation.

The second approach used to evaluate sea level rise inundation was the Sea Level Affecting Marshes Model (SLAMM). The model requires a digital elevation model (DEM) layer, a slope layer (derived from the DEM), a detailed land-use layer, 
parameters for tidal ranges (NOAA, 2007), and if known, accretion rates for nearby marshes. The land-use layer was created by merging Coastal Change Analysis Program data (NOAA, 2006) and National Wetlands Inventory data (USFWS, 2010) and recoding them to SLAMM categories as specified by the User Manual (Warren Pinnacle Consulting, 2010). Some accretion parameters were obtained from Surface Elevation Table (SET) data (Lynch, 2012; NPS, 2009). When parameters were unknown or unavailable, SLAMM's default settings were used. Using linear relationships and decision tree rules, SLAMM calculates water elevation at a particular location, and computes inundation and habitat response over large areas (Mcleod et al., 2010). The output maps showed expected habitat classes and areas of inundation based on the different rates and magnitudes of sea level rise. Sentinel site locations were mapped over the output. Change matrices were created to show changes from initial habitat to the predicted habitat for each sentinel site.

\section{Storm Surge Scenarios}

The SLOSH (Sea, Land and Overland Surges from Hurricanes) model, a forecast model for hurricane-induced water levels for the Gulf and Atlantic Coasts (Jelesnianski, Chen, and Shaffer, 1992) was used to model expected surge heights along park coasts from Saffir-Simpson Category 1-4 hurricanes. Surge heights are not uniform along the coastline and depend on the hurricane track, wind speed, and topography and bathymetry at the point where the storm makes landfall (FEMA, 2003). Storm surge heights were derived from the Providence/Boston and Ocean City storm basins in SLOSH and used as input in the Applied Science Associates, Inc. (ASA) Inundation Toolbox - Interpolation tool (Isaji and Knee, 2009). The tool 
interpolated the point heights to a raster surface of the same extent and resolution as the DEM. Elevations from the DEM were compared to the elevations from the storm surge surfaces and probabilities of inundation at sentinel sites were calculated using the z-score uncertainty technique described above. The uncertainty technique incorporated known sources of error unique to the water surface modeled by SLOSH. For each of the four storm scenarios, two probabilities were calculated: one given the elevation of a sentinel site from the DEM and another given the elevation of a sentinel site from the RTK GPS survey.

ArcGIS 10 software was used for all geospatial data processing (ESRI, 2011). A summary of the models used and sources of data are provided in Table 1.

\section{Statistical Procedures}

At each sentinel site, probabilities of inundation were calculated for three sea level rise scenarios $(0.6 \mathrm{~m}, 1 \mathrm{~m}, 2 \mathrm{~m})$, four storm surge scenarios (Category 1-4) and two sources of elevation data. Descriptive statistics were calculated for each risk estimate variable and the variables were tested for normality using the Shapiro-Wilk normality test. Because data were usually non-normally distributed, I performed pairwise comparisons using the non-parametric Wilcoxon signed rank test, and where there were 3 or more groups in a comparison, I used the Kruskal-Wallis rank sum test. When data were normally distributed, I used the paired t test for pairwise comparisons. A principal components analysis (PCA) was used to reduce the large number of risk measures to a smaller number of variables in order to develop a composite measure of inundation risk at sentinel sites. All analyses were conducted using the statistical software package R (R Development Core Team, 2011). 


\section{RESULTS}

\section{Elevations of Sentinel Sites}

Sentinel sites are locations of natural, cultural and infrastructural resources of special importance to the National Park Service and were provided by park managers. At BOHA, sentinel site locations included stone sewage basins of historical importance, a unique cattail marsh habitat, a historical cemetery, and Fort Strong, a Civil War era military site. At CACO, sentinel site locations included groundwater monitoring wells, lighthouses, visitor centers, and historical monuments and sites, e.g., Marconi Site and Marindin survey markers (Marindin, 1891). At ASIS, sentinel sites were locations of 34 newly installed or frequently used geodetic survey markers which are critical for scientific research on the islands. The sentinel sites' elevations obtained from RTK GPS and LiDAR-derived DEMs were significantly different. At CACO and BOHA, the LiDAR elevations were lower than RTK GPS elevations, and at ASIS the LiDAR elevations were often higher than RTK GPS elevations (Table 2); complete lists of sentinel sites and their elevations can be found in Appendix 3 (Tables A3.1A3.3).

\section{Quality of the LiDAR Data}

The metadata for each of the three LiDAR-derived DEMs reported a $0.15 \mathrm{~m}$ vertical root mean square error (RMSE). To validate the accuracy estimates, I calculated the vertical RMSE using ground control points of high quality and accuracy ( $<2 \mathrm{~cm}$ vertical and horizontal accuracy) collected using survey-grade GPS (Table 3).

For BOHA, I obtained the control points on a RTK GPS surveying expedition in 2012. Using 21 control points, the vertical RMSE of the LiDAR DEM for the 
islands was $1.65 \mathrm{~m}$. To verify my result and account for the low number of control points, I extended the scope of the assessment and used high quality (i.e. elevation order $=1$ ) National Geodetic Survey (NGS) monumentation to calculate the accuracy of the LiDAR DEM in the Metropolitan Boston area using the same LiDAR dataset. Using these 20 additional control points, the vertical RMSE was found to be $1.53 \mathrm{~m}$. This result meant that the BOHA LiDAR could not be used for modeling sea level rise and storm surge on the scales proposed (see discussion of elevation in Appendix 1). For elevation data of this quality, NOAA (2010) recommends that the lowest increment of sea level rise to be modeled is $3.3 \mathrm{~m}$; the more conservative recommendation is $6.6 \mathrm{~m}$ (CCSP, 2009). As a consequence of this finding, inundation risk at sentinel sites in BOHA could not be calculated using the 2002 MassGIS LiDAR data.

For CACO, the control points were obtained from the park's surveys in 20042009 and from the URI-NPS monumentation project surveys of recently installed and stable existing geodetic monumentation in 2011 (Murdukhayeva et al., 2012). Using 35 control points, the vertical RMSE of the LiDAR DEM was $0.53 \mathrm{~m}$.

For ASIS, the control points were obtained from topographic profiles collected in 2010, and from surveys of geodetic monumentation in 2011 (Murdukhayeva et al., 2012). For ASIS, the vertical RMSE was $0.33 \mathrm{~m}$. Based on the recommendations of NOAA (2010), vertical accuracies were sufficiently high for ASIS that inundation models could be run for all three sea level rise scenarios $(0.6 \mathrm{~m}, 1 \mathrm{~m}, 2 \mathrm{~m})$. LiDAR data for CACO were accurate enough so that inundation probabilities could be reasonably estimated for the $1 \mathrm{~m}$ and $2 \mathrm{~m}$ scenarios. 


\section{Inundation Models}

Sea level rise scenarios were mapped and are shown for selected parts of CACO (Figure 2) and ASIS (Figure 3). Maps with park-scale views of each scenario modeled are found in Appendix 5 (Figures A5.1-A5.5). Expected surge heights from Category 1-4 storms were modeled at CACO and ASIS (Table 4). The bath-tub and storm surge models were used to map areas at risk from inundation. An area was considered at risk from inundation if it had an elevation less than or equal to the water surface elevation that was expected in any given location (Table 5). In order to account for topographic features that may prevent inundation of inland areas, only raster cells adjacent to the ocean or adjacent to other inundated cells were included in the calculations (see Appendix 2). Areas at risk from storm surge inundation are mapped and shown for selected parts of CACO (Figure 4) and ASIS (Figure 5). Maps with park-scale views of each category hurricane modeled are found in Appendix 5 (Figures A5.6-A5.13). The extent of LiDAR coverage closely follows National Park Service boundaries shown in the maps.

\section{Probabilities of Inundation}

Each sentinel site was intersected onto the scenario's modeled water surface and probabilities of inundation were calculated using equations 1 - 3. Probabilities were determined using the RTK GPS and LiDAR elevations. Mean probabilities from RTK GPS elevations are reported (Table 6 and Table 7) due to their higher accuracy. The complete list of sentinel sites and probabilities of inundation can be found in Appendix 4 (Table A4.1). 
The mean probabilities of inundation at CACO were significantly different under the two sea level rise scenarios (Wilcoxon signed rank $V=0, p<0.001$ ). At ASIS, the mean probabilities of inundation were significantly different under the three sea level rise scenarios $(\mathrm{H}=66.02, \mathrm{df}=2, \mathrm{p}<0.0001)$. The mean probabilities of inundation for four storm surge scenarios were significantly different in both CACO $(\mathrm{H}=44.51, \mathrm{df}=3, \mathrm{p}<0.0001)$ and ASIS $(\mathrm{H}=96.52, \mathrm{df}=3, \mathrm{p}<0.0001)$.

\section{Habitat Changes Predicted by SLAMM}

The SLAMM model predicted habitat classes under selected sea level rise scenarios by the year 2100. Change matrices show the number of sentinel sites in each habitat class initially, and their expected conversions as a result of sea level rise. In CACO, only 2 scenarios were modeled because of the vertical accuracy of the LiDAR data (the primary input driving the model) was inadequate to support the $0.6 \mathrm{~m}$ scenario. Many of the sentinel sites were originally in the "Developed Dry Land" category (12 out of 63) and remained unchanged because one of the assumptions of the model is that developed dry land would be protected by human actions over time. This may not be an appropriate assumption for some National Park study sites. A few sentinel sites in the "Undeveloped Dry Land" category experienced conversions to “Transitional Marsh," "Estuarine Beach,” and in one case, to "Open Ocean" after 2 m of sea level rise (Table 8). In ASIS, many sentinel sites were in the "Undeveloped Dry Land" class (24 out of 34) and experienced conversions to "Transitional Marsh," "Estuarine Beach," "Ocean Beach," and "Open Ocean". Points that started out in the "Irregularly Flooded Marsh" converted to "Salt Marsh" after 2 m of sea level rise 
(Table 9). According to the recommendation of Scarborough (2009), similar classes were aggregated for ease of interpretability (Table 10 and Table 11).

Similarly, mapping the SLAMM output with the aggregated classes aided in interpretability. Figure 6 shows initial conditions, and a $1 \mathrm{~m}$ sea level rise output with the original classification scheme (top panels) and with the aggregated classification scheme (bottom panels). An area east of Calfpen Bay showed great changes over the modeled scenarios (Figure 7); there was a large increase in marsh, transitional marsh and open water areas. These changes are clearer to visualize using the aggregated land cover classes.

Maps with park-scale views of initial land cover classes and model output land cover classes for each sea level rise scenario modeled are found in Appendix 5 (Figures A5.14-A5.20).

\section{Overall Inundation Index}

The three modeling methods yielded several measures of inundation risk. I used Principal Components Analysis (PCA) to reduce the large set of correlated variables to a set of uncorrelated variables called principal components. The first principal component (PC1) explained $63 \%$ of the total variation in risk measures at CACO and $58 \%$ of the total variation in risk measures at ASIS. In all cases, inundation probabilities had a negative loading and RTK GPS elevations had a positive loading on PC1 (Table 12). Nearly all variables had similar loading values on PC1, thus PC1 represents a "size" effect (August, 1983) and is an excellent index of overall inundation likelihood. The other principal components had high loadings on only one or two variables and reflected specific risk factors. Furthermore, they did not 
predict a large amount of overall variation, thus are not candidates for an overall risk index. The range of PC1 values for each park was separated into five quintiles. Large positive PC1 scores for sentinel sites indicate that inundation is very unlikely; large negative PC1 scores indicate that inundation is very likely (Table 13). Sentinel sites' raw PC1 scores are given in Table A4.1. Overall inundation index classification at sentinel sites is mapped for CACO (Figure 8) and ASIS (Figure 9). 


\section{DISCUSSION}

\section{Quality of Elevation Data}

The poor accuracy of the BOHA LiDAR data and the reduced spatial extent of the CACO LiDAR data were limiting factors in my analyses of sea level rise and storm surge vulnerability. Differences in data accuracies are likely due to differences in the data collection technologies. The Boston LiDAR data were collected in 2002 using the Digital Airborne Topographic Imaging System II (DATIS II), while the CACO and ASIS LiDAR data were collected in 2005 and 2009, respectively, using the Experimental Advanced Airborne Research LiDAR (EAARL) system (Bonisteel et al., 2009). Furthermore, different geoid models were used to compute the elevations for the DEMs. A geoid is a representation of the equal gravitational potential surface of the earth, or the sea level surface of the earth, and a geoid model is used to convert heights from the NAD83 ellipsoid reference system to the NAVD88 vertical datum (NGS, 2011). The BOHA and CACO DEMs were computed with the Geoid99 model, while the ASIS DEM was computed using the Geoid09 model. All RTK GPS points were computed using the Geoid09 model. For the Boston region, I found a $2 \mathrm{~cm}$ difference in elevations between the two geoid models using the NGS Geodetic Toolkit (NGS, 2011). This explains a small part of the results I obtained in the accuracy assessment of the LiDAR data. However, the poor vertical accuracy of the BOHA LiDAR data $(1.65 \mathrm{~m})$ was significantly greater than the error from mixing geoid models $(2 \mathrm{~cm})$. All three of the LiDAR datasets had reported vertical RMSE of $0.15 \mathrm{~m}$. If I had used the BOHA LiDAR data for the inundation modeling using the reported vertical error, the results would have been seriously misleading. Therefore, it 
is prudent to independently evaluate the vertical accuracy of the elevation data used to be certain they meet the requirements of the analysis.

The excellent quality of the RTK GPS elevation data was an important asset for this project. GPS field surveys allowed us to collect accurate elevations of sentinel sites that most likely could not be reached by LiDAR signals and sensors (NOAA CSC, 2010b). For example, we surveyed elevations of groundwater monitoring wells located in forests with heavy canopy cover. Because these elevations were measured with great accuracy using the RTK GPS (0.006-0.087 m), inundation probabilities were calculated with greater certainty. The application of RTK GPS is a promising solution to elevation uncertainty issues in sea level rise inundation risk assessments. It is important to note, however, that RTK GPS protocols require operating a GPS base station at a location that has been surveyed to within a few millimeters. Thus, a network of accurate geodetic control sites within $5 \mathrm{~km}$ of potential sentinel sites is an essential requirement for RTK GPS measurement (Murdukhayeva et al., 2012).

\section{Inundation Models}

Bath-tub modeling is a technique that tends to overestimate inundation extents and calculate uncertain predictions (Mcleod et al., 2010; Poulter and Halpin, 2008). The use of high accuracy RTK GPS equipment helped minimize the error in estimating inundation risk. Because the error associated with each sentinel site elevation was low, there was less uncertainty associated with each modeled scenario, i.e. many of the sentinel sites had probabilities of inundation of either 0 (very unlikely) or 1 (very likely). This was not the case with probabilities of inundation calculated using elevations at sentinel sites based on LiDAR data, where many probabilities of 
inundation were included in the range of 0.25 to 0.75 . Therefore, the LiDAR-derived DEMs were used only for mapping areas at risk and providing a map assessment of the extent of inundation (Figures 2-5 and A5.1-A5.13). Inundation probabilities at sentinel sites using LiDAR-derived elevations were not used for developing the overall inundation index.

One of the most valuable products of this assessment is the range of storm surge heights modeled by SLOSH (Table 4). These surge heights can be used for predictions of hurricane impacts in the near future. For example, the SLOSH model predicted extensive inundation in Provincetown and the salt marsh sites in Cape Cod. Sentinel sites at Provincetown Airport, Pleasant Bay Marsh, and Wellfleet Harbor are at risk under the Category 3 and 4 hurricane scenarios. Along the entire length of Assateague Island, sentinel sites are at high risk. Under the Category 2 scenario, 22 sentinel sites have greater than $75 \%$ probability of inundation, and under the Category 3 and 4 scenarios, all 34 sentinel sites have greater than $75 \%$ chance of inundation. The potential damage to a sentinel site resource under conditions of storm surge inundation varies depending on the nature of the site. Buildings or historical artifacts could face extensive damage whereas certain habitats or hard infrastructure (roads, geodetic monuments) might not be damaged at all during a brief period of inundation. Thus, it is important that the National Park Service evaluate risk for each site and develop mitigation plans accordingly.

\section{SLAMM}

The SLAMM model was limited by the quality of the data driving the model (LiDAR-derived DEMs). Using the RTK GPS elevations to enhance the results of the 
model was not possible. An important baseline dataset for the SLAMM model was initial land use classification. In this study, initial land use conditions were obtained from National Wetlands Inventory maps created using aerial photography from 1988 (ASIS) and 1993 (CACO), and as a result these maps did not reflect changes that might have occurred over the past two decades. Furthermore, there is no way to quantitatively determine the uncertainty associated with a SLAMM prediction. These factors and others limit the output results (Kirwan and Guntenspergen, 2009; Scarborough, 2009).

For the risk assessment, I was most interested in identifying predicted land cover changes to open water, i.e. inundation. At CACO, one site (1 m scenario) and three sites (2 m scenario) are expected to experience inundation. At ASIS, four sites (1 m scenario) and 12 sites ( 2 m scenario) are expected to be inundated. The bath-tub model predicts greater amounts of inundation (Table 6). At CACO, three (1 m scenario) and 11 sites ( $2 \mathrm{~m}$ scenario) have probabilities of inundation greater than 75\%, and at ASIS, 11 (1 m scenario) and 32 (2 m scenario) sites have probabilities of inundation greater than $75 \%$. This difference confirms the notion that bath-tub models over estimate inundation (Mcleod et al., 2010; NOAA, 2010), but it may also suggest that SLAMM under estimates inundation.

In presenting the SLAMM output in maps, it was important to stress the uncertainty of habitat predictions due to errors in input elevation and land cover maps. To increase the interpretability of the SLAMM results, I aggregated the 11 possible SLAMM classes into five land cover categories for mapping applications: upland, forested wetland, marsh, beach, and open water (Figures 6 and A5.14-A5.20). These 
maps will be a useful tool for managers interested in wetland-specific predictions and comparing modeling approaches.

\section{Overall Inundation Index and Implications for Sentinel Sites}

For the most part, Cape Cod's sentinel sites were located in high elevation areas inland; 39 of the 63 sentinel sites have elevations greater than $5 \mathrm{~m}$ above MHHW and as a result, not many sites are at risk from sea level rise or storm surge inundation. For example, the base of Highland Lighthouse is located at $39.34 \mathrm{~m}$ NAVD88 or $38.41 \mathrm{~m}$ above MHHW (Figure 10). Several sites that were found to be at risk are very close to current tide levels. For example, one sentinel site at CACO, a culvert near Wellfleet Harbor, was almost submerged at high tide on our survey trip (Figure 11). One PVC survey marker in Pleasant Bay and NGS monuments at the Provincetown airport are at risk as well. These findings agree closely with the results of Hammar-Klose et al.'s (2003) Coastal Vulnerability Index assessment (Figure A6.1). In their study, segments of shoreline were ranked low to high vulnerability using an index that combined geological and physical variables. The locations of high vulnerability sentinel sites as ranked by the Inundation Index tend to appear immediately inland of those shoreline segments with a high CVI vulnerability rank.

At Assateague Island, all of the sentinel sites were in low elevations below 2.6 m. Many of them are at risk from sea level rise and storm surge from large hurricanes. The CVI assessment (Pendleton, Williams, and Thieler, 2004) at ASIS (Figure A6.2) and spatial pattern of the overall Inundation Index corroborate each other also. Disagreement occurs at points near the Chincoteague Inlet. The CVI rates that shoreline as low vulnerability because of high accretion rates, and the Inundation 
Index rates sentinel sites in that area as high vulnerability because of the low elevations.

\section{Directions for Future Work}

The study presented here assessed inundation risk at 97 sentinel sites located in two northeastern U.S. coastal National Parks. The methodology I used can be applied at other coastal parks and at the same parks at future dates and with future datasets. Models of sea level rise and storm surge are continually being refined and inundation probabilities can be recomputed as new models are developed. Estimates of sea level rise are evolving as new data from satellite altimetry and ice melt studies are acquired. The National Weather Service updates SLOSH's storm surge predictions for regional basins following large hurricane events. Furthermore, LiDAR data are being acquired for large regions of the United States coast in order to evaluate sea level rise and storm surge risk. For example, the USGS recently completed a large area LiDAR acquisition for coastal areas of the Northeast. These new data will hopefully resolve the data quality issues I encountered in this study. The use of RTK GPS technology to collect accurate elevations at sentinel sites is a promising research direction that will allow park managers to better predict inundation risk using best available sea level rise and storm surge predictions. However, establishing a network of stable, accurate geodetic control sites to form a backbone of base station locations is a prerequisite to using RTK GPS for rapid elevation data acquisition (Murdukhayeva et al., 2012). 


\section{FIGURES}

Figure 1: Regional map with locations of the study areas.

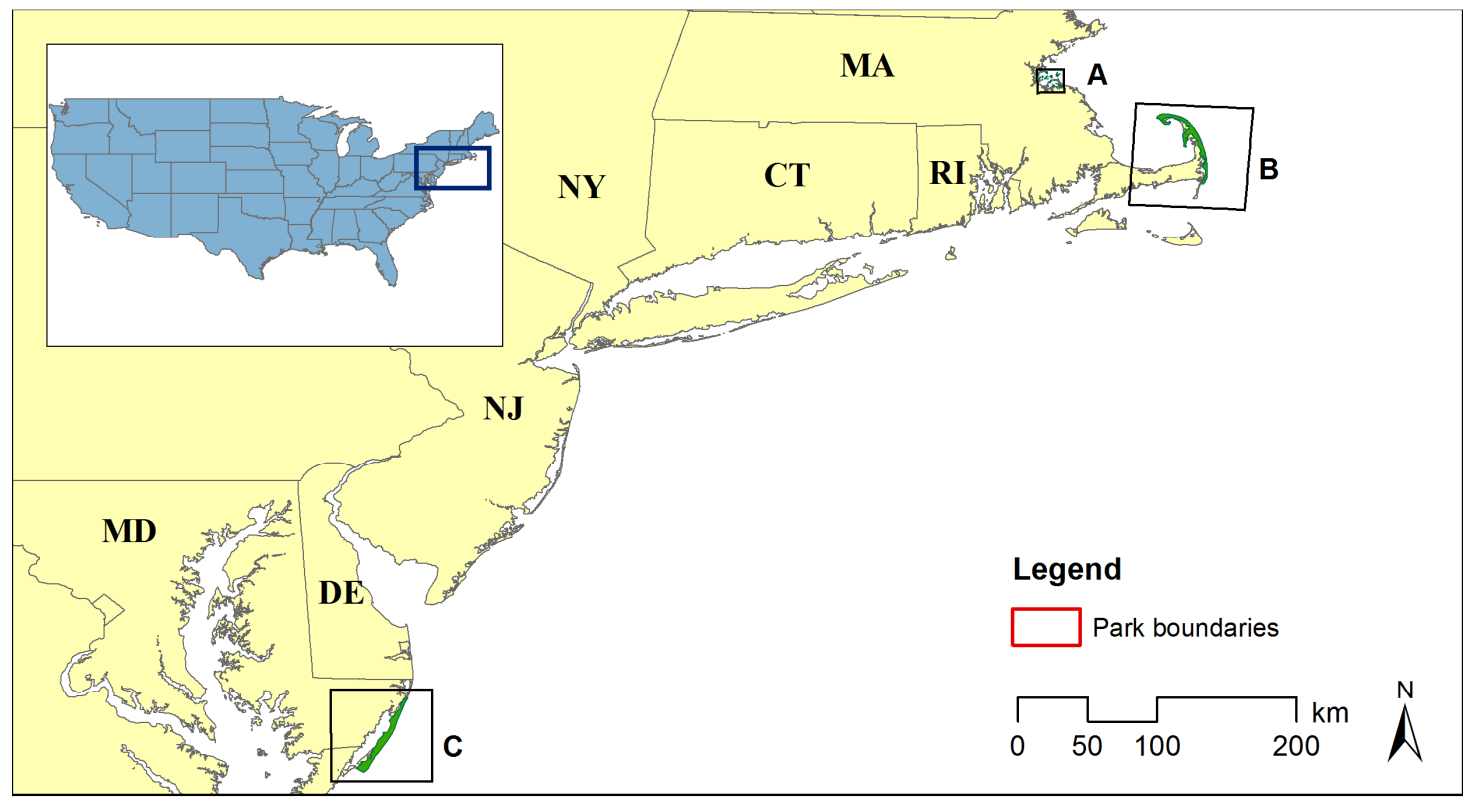

A. Boston Harbor Islands NRA

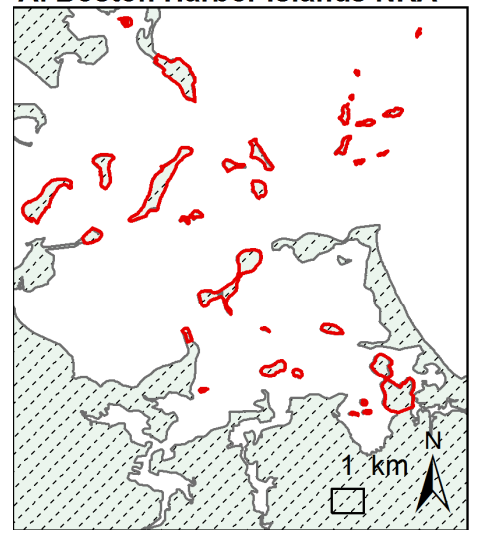

B. Cape Cod NS

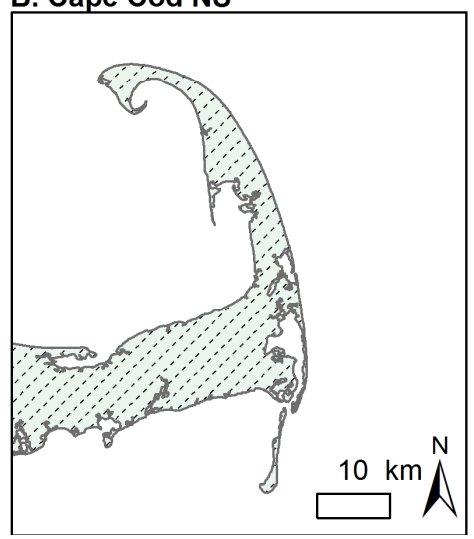

C. Assateague Island NS

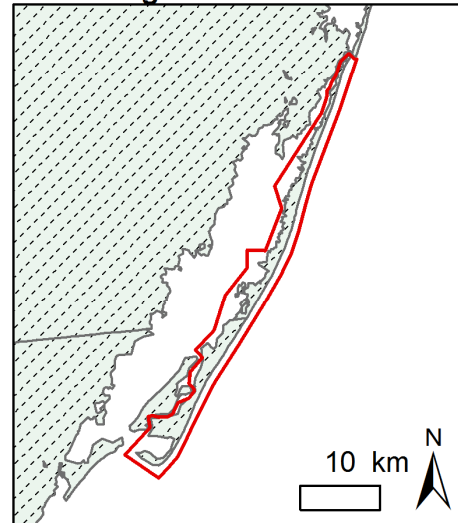


Figure 2. Sea level rise scenarios at Cape Cod. The blue areas represent areas at risk from inundation in $1 \mathrm{~m}$ and $2 \mathrm{~m}$ sea level rise scenarios. The areas in orange represent areas whose elevations are under the $1 m$ and $2 m$ water surfaces, but are unconnected to the ocean or other areas expected to be inundated.
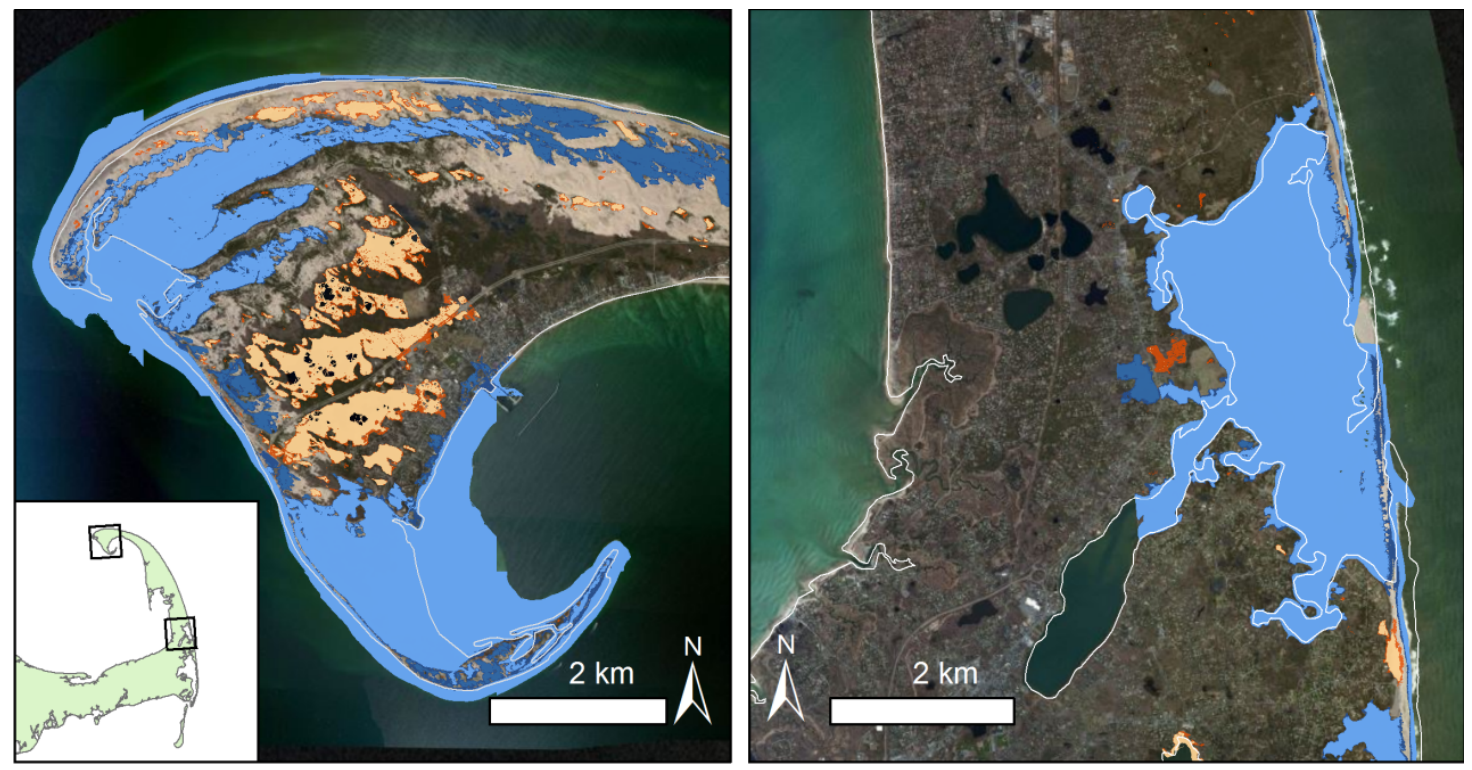

\section{Legend}

Shoreline

Below 1m, unconnected

1 meter

Below $2 \mathrm{~m}$, unconnected

2 meters 
Figure 3. Sea level rise scenarios near Verrazano Bridge, Assateague Island. A. 0.6 m; B. $1 \mathrm{~m} ; \mathrm{C} .2 \mathrm{~m}$
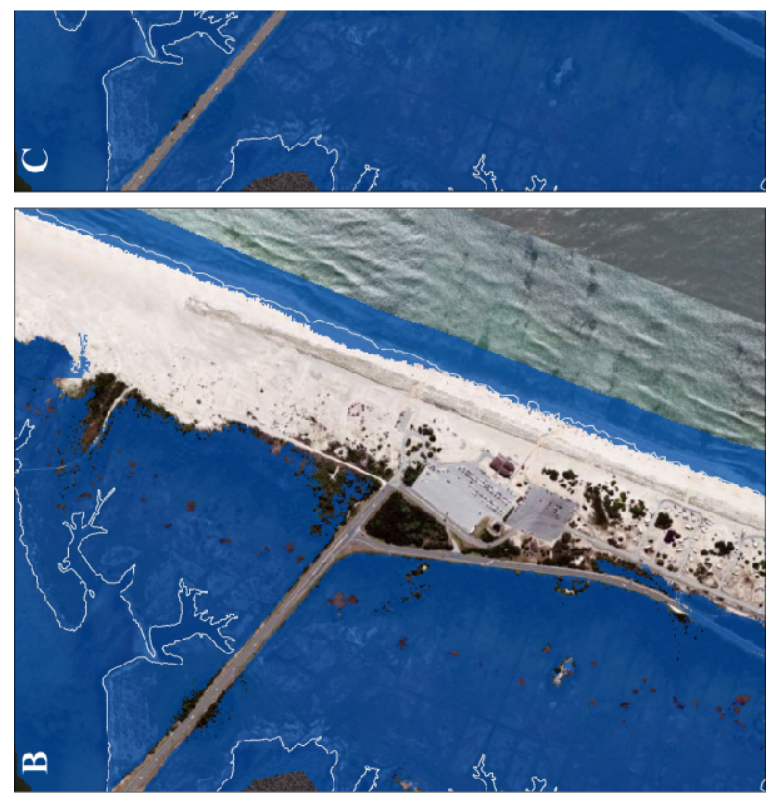

Figure 4. Inundation expected from storm surges at Cape Cod. A. Category 1; B. Category 2; C. Category 3; D. Category 4 

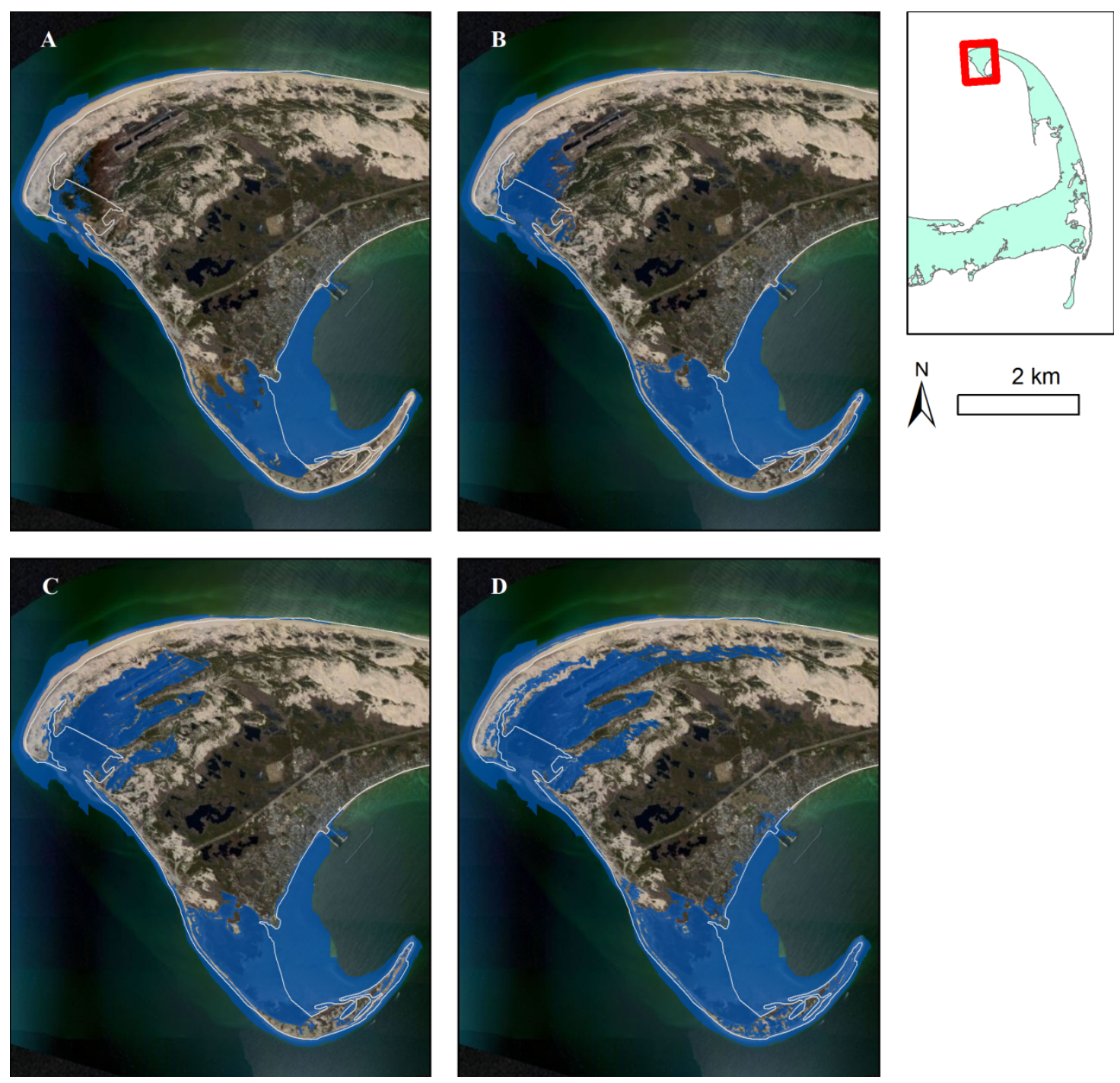
Figure 5. Inundation expected from storm surges at Assateague Island. A. Category 1; B. Category 2; C. Category 3; D. Category 4
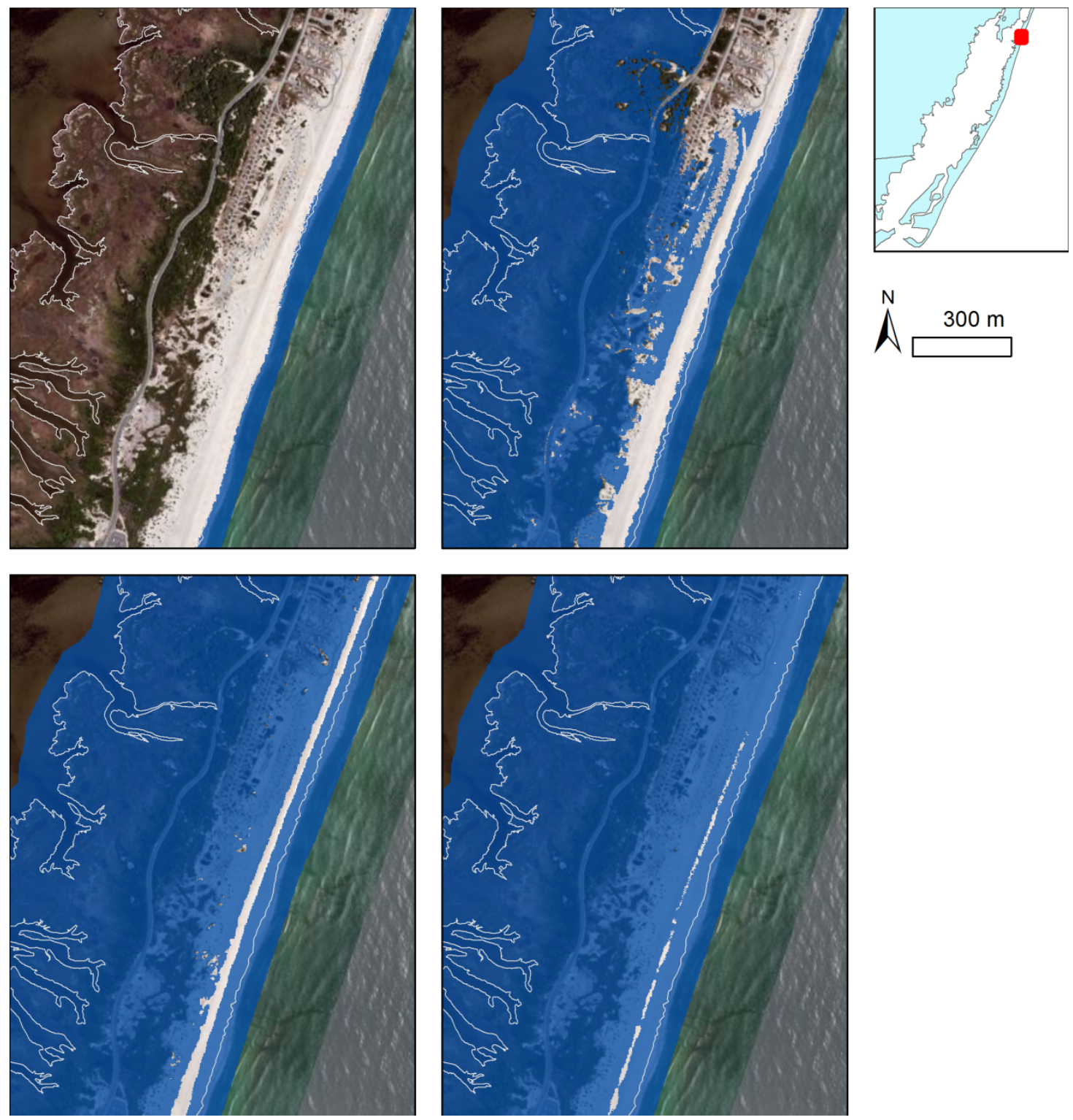
Figure 6. SLAMM initial conditions and model output at Assateague Island. Eleven possible land use classes in study area (top panels), and land use classes aggregated into five broad groups (bottom panels).
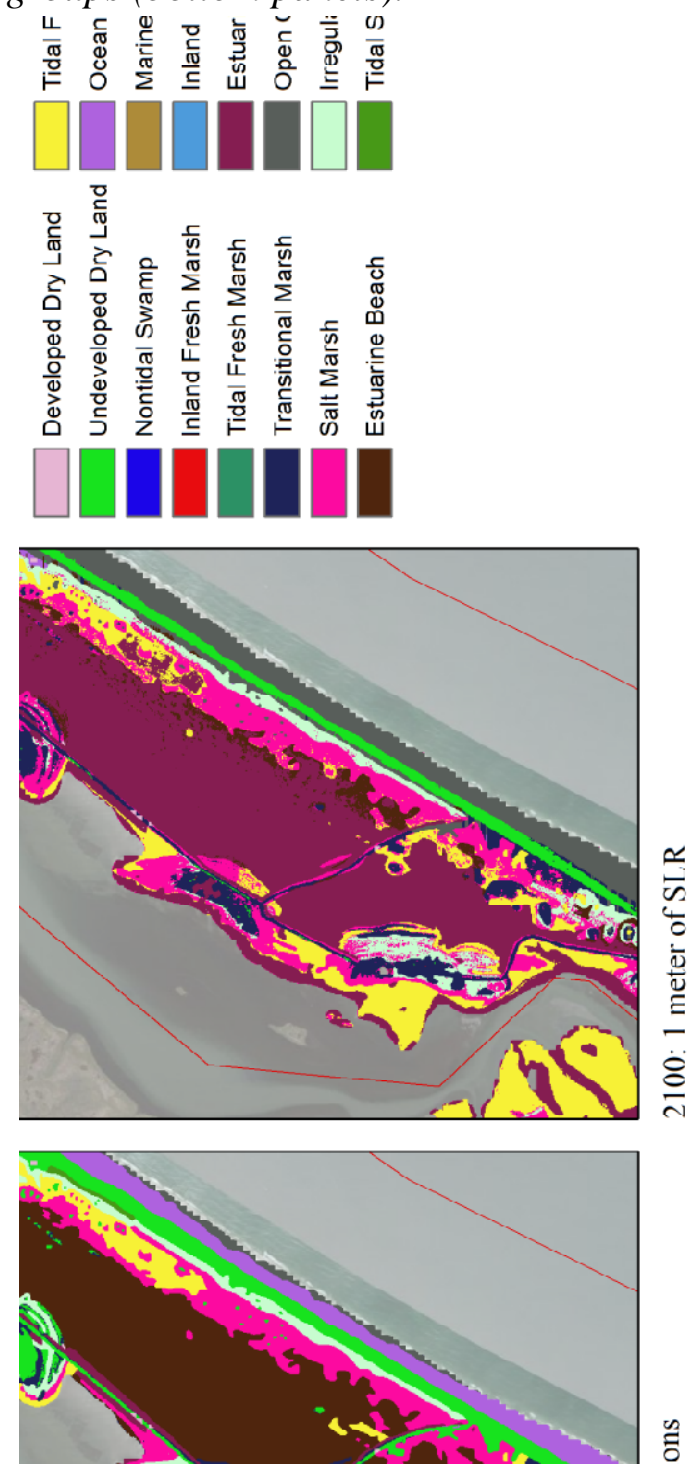
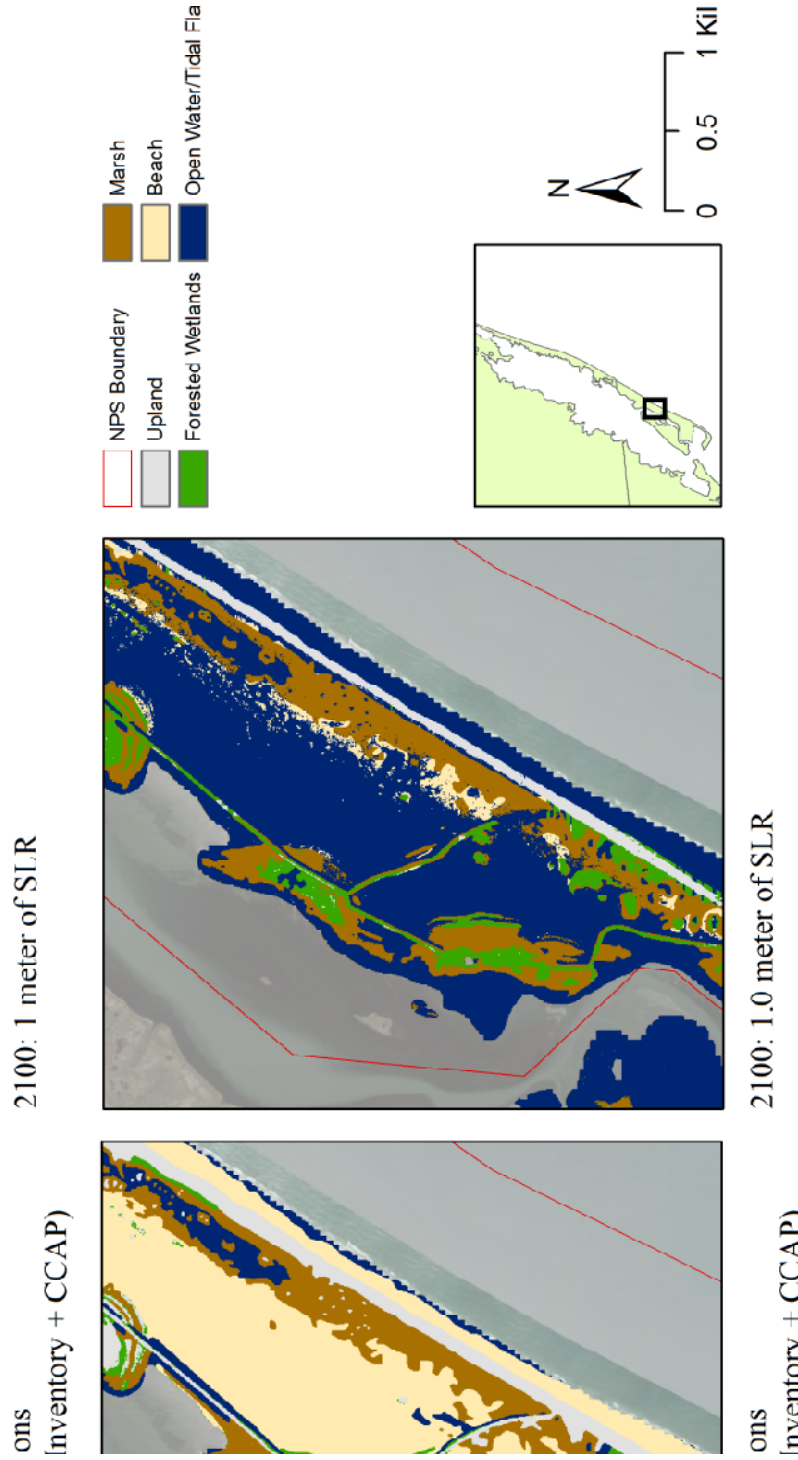

言总 
Figure 7. SLAMM output at Assateague Island. Eleven possible land use classes in this study area aggregated into five broad groups for ease of interpretation.

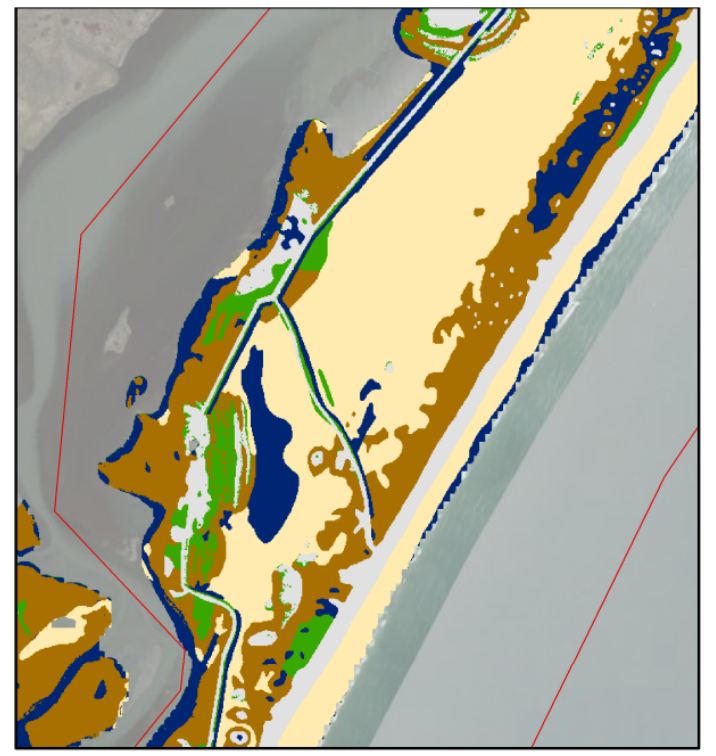

1988: Initial Conditions

(National Wetlands Inventory + CCAP)

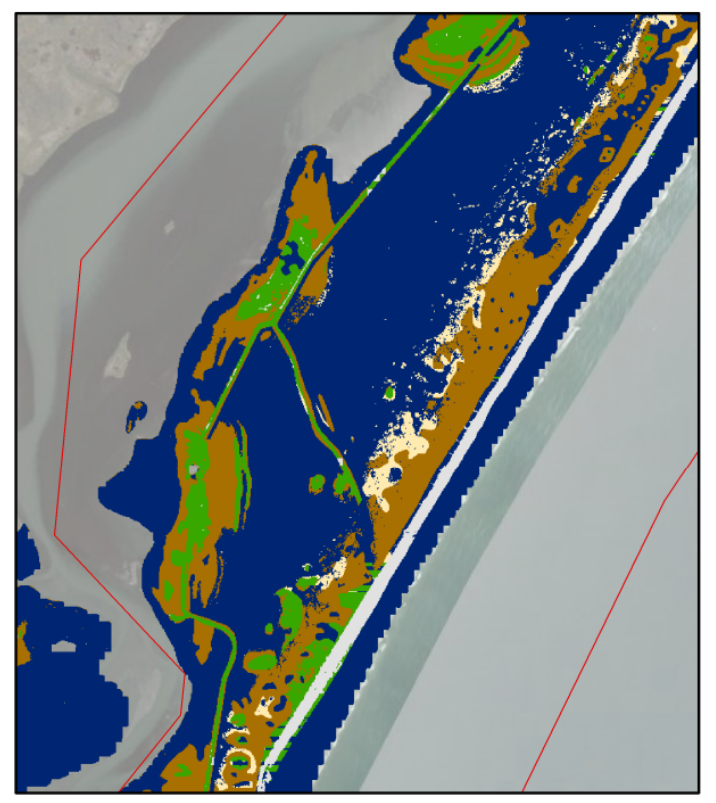

2100: 1.0 meter of SLR

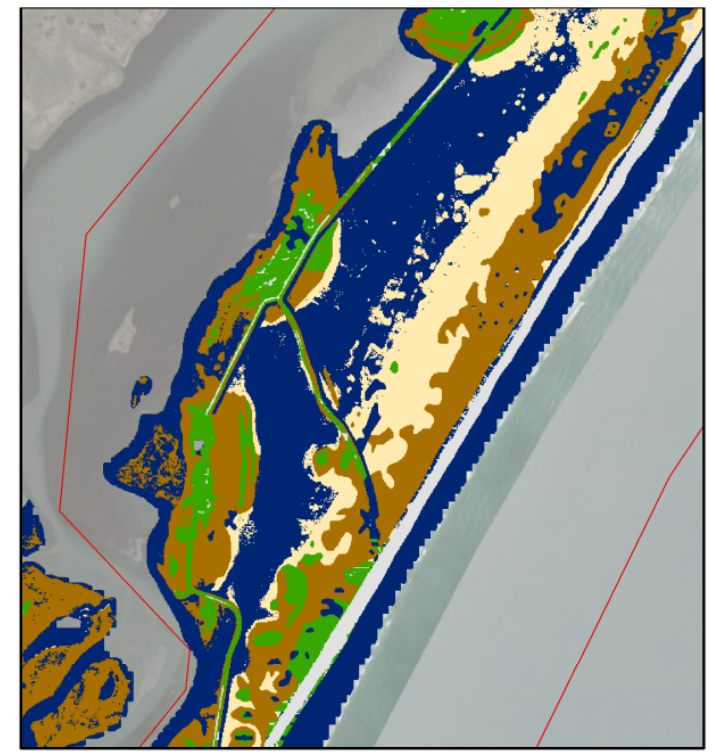

2100: 0.60 meter of SLR

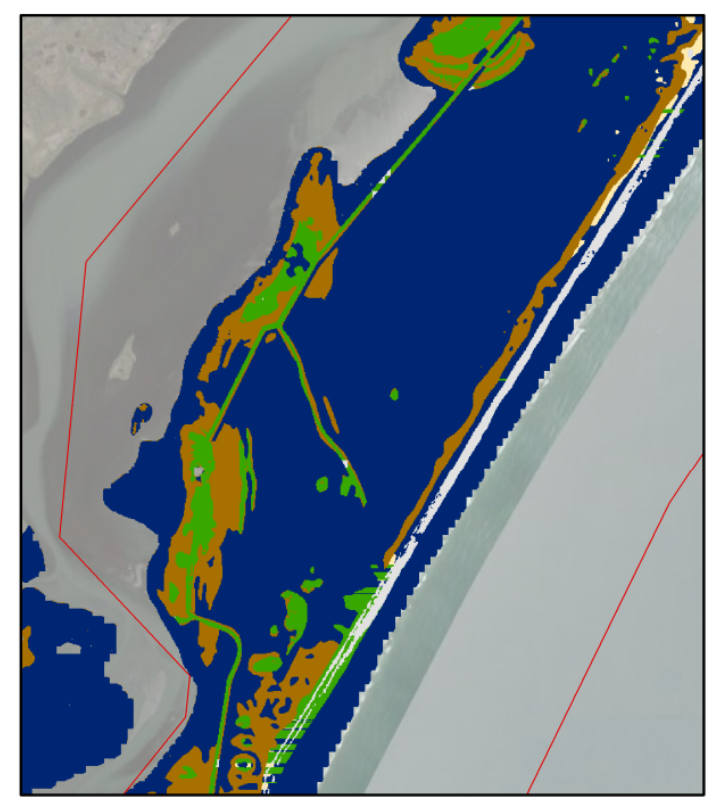

2100: 2.0 meter of SLR

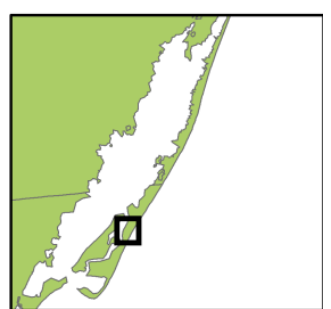


Figure 8. Overall inundation index for sentinel sites at CACO. Blue points indicate sites where inundation is very unlikely and red points indicate sites where inundation is very likely.

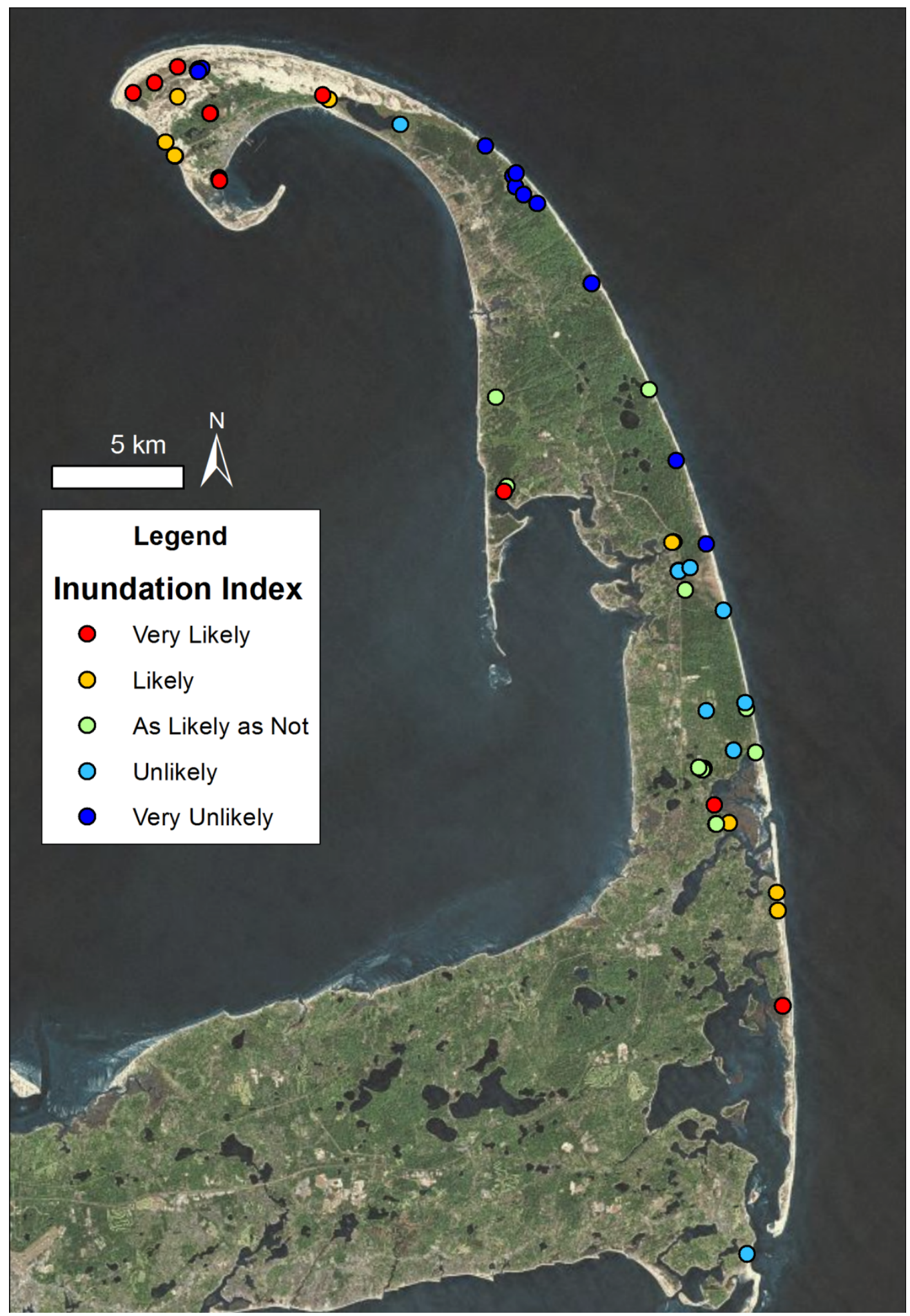


Figure 9. Overall inundation index for sentinel sites at ASIS. Blue points indicate sites where inundation is very unlikely and red points indicate sites where inundation is very likely.
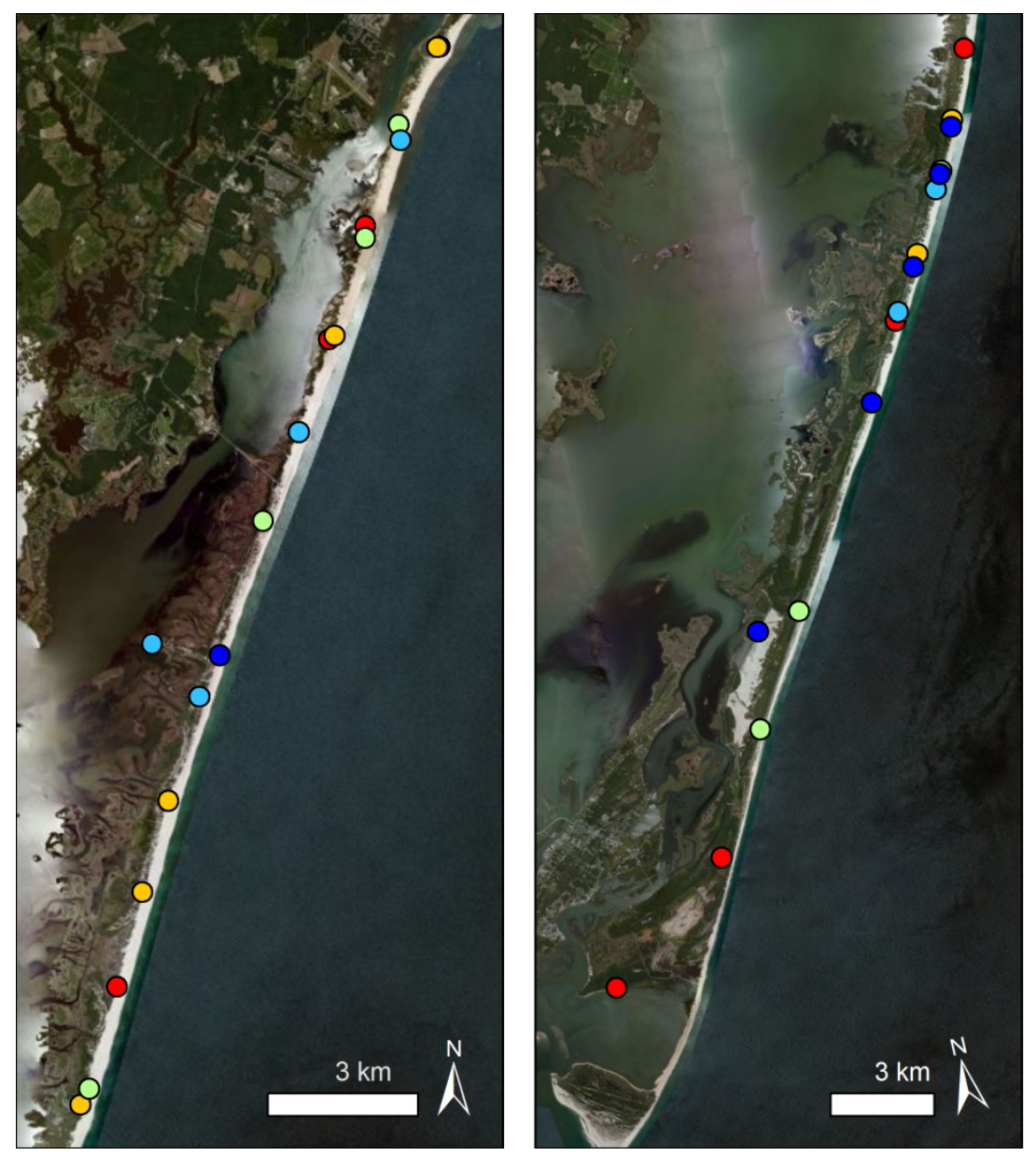

\section{Legend} Inundation Index

- Very Likely

O Likely

As Likely as Not

O Unlikely

- Very Unlikely

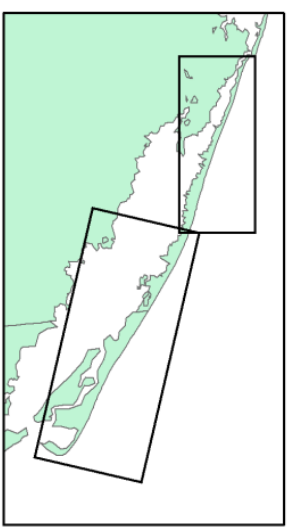


Figure 10. Sentinel site with low relative likelihood of inundation. Highland Lighthouse in North Truro, MA.

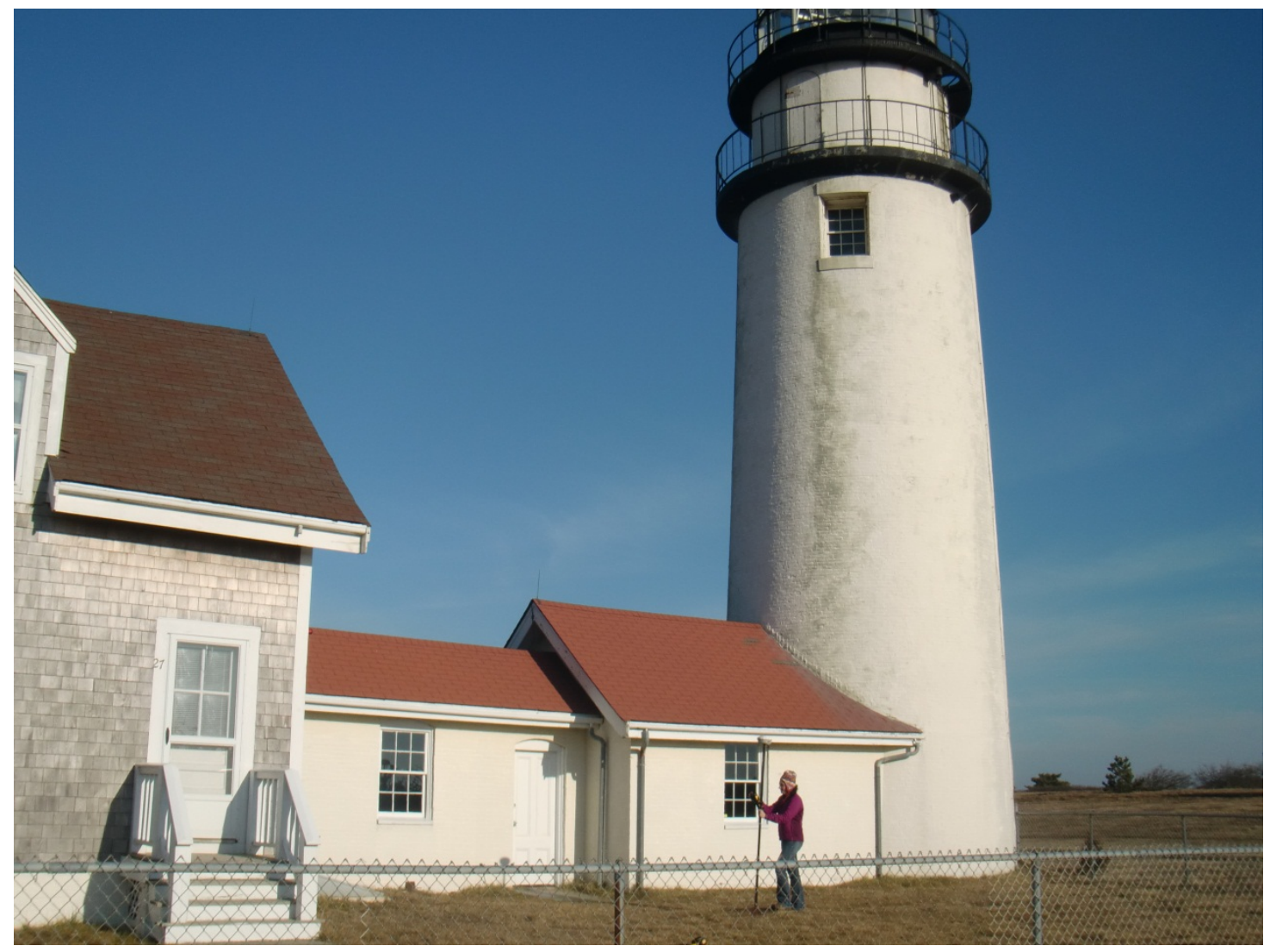


Figure 11. Low-lying sentinel site at Cape Cod National Seashore. A culvert near a bike path in Wellfleet, MA.

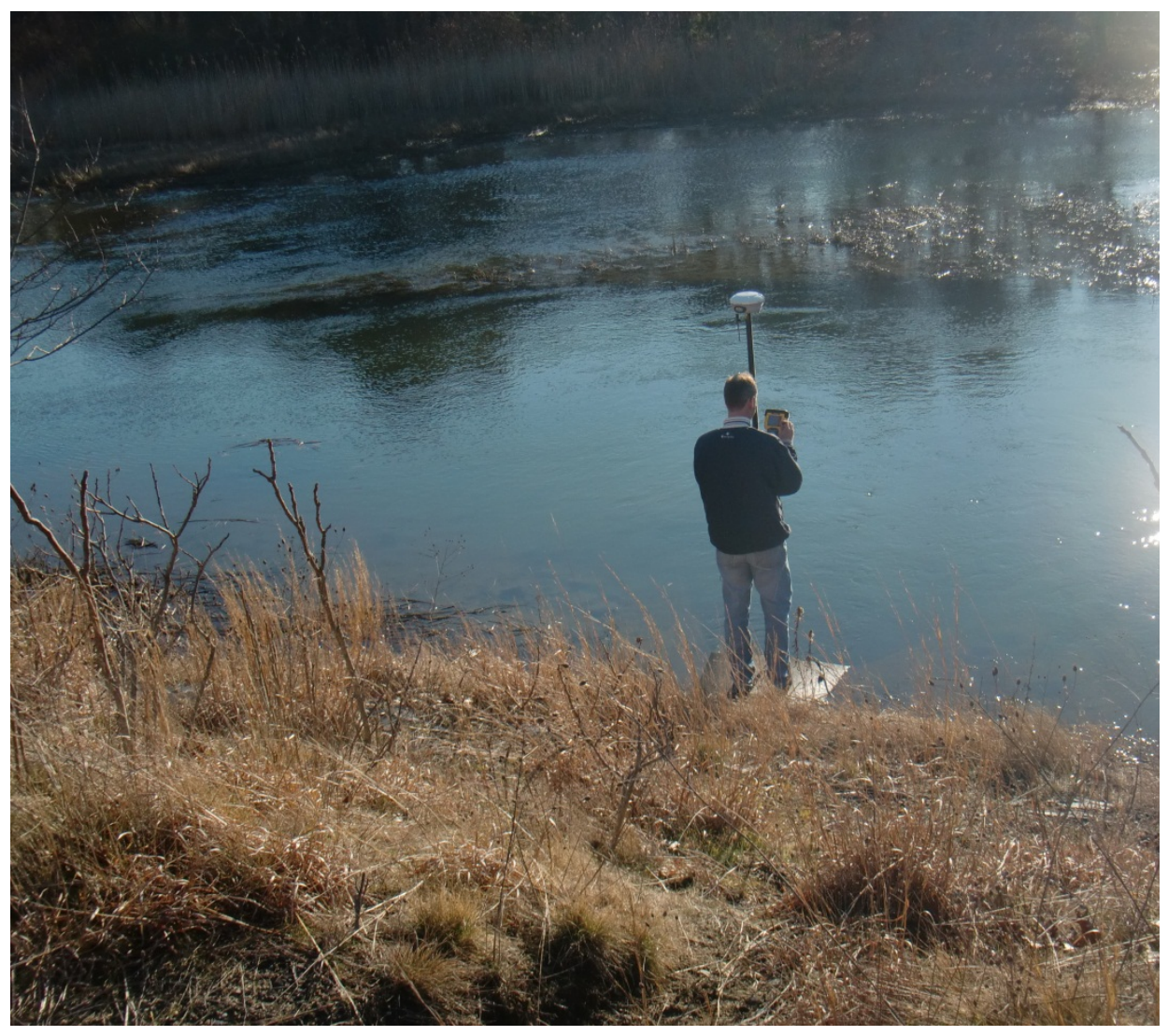




\section{TABLES}

Table 1. List of data, tools and sources.

\begin{tabular}{|c|c|c|}
\hline Data/Tool & Source & Citations \\
\hline Elevation & $\begin{array}{l}\text { Experimental Advanced } \\
\text { Airborne Research Lidar } \\
\text { (EAARL), 3di } \\
\text { Technologies Inc.'s } \\
\text { Digital Airborne } \\
\text { Topographic Imaging } \\
\text { System II (DATIS II), } \\
\text { RTK GPS Surveys }\end{array}$ & $\begin{array}{l}\text { Performed by Neil Winn } \\
\text { (NPS ASIS), Mark } \\
\text { Adams (NPS CACO), } \\
\text { Michael Bradley (URI) } \\
\text { and Angelica } \\
\text { Murdukhayeva (URI) }\end{array}$ \\
\hline $\begin{array}{l}\text { Tidal and orthometric } \\
\text { datum values }\end{array}$ & $\begin{array}{l}\text { NOAA CO-OPS, } \\
\text { NOAA VDatum } 3.0 \text { beta }\end{array}$ & $\begin{array}{l}\text { (NOAA, 2007; NOAA, } \\
\text { 2011) }\end{array}$ \\
\hline $\begin{array}{l}\text { SLOSH (Sea, Land and } \\
\text { Overland Surges from } \\
\text { Hurricanes) Model }\end{array}$ & $\begin{array}{l}\text { NOAA National } \\
\text { Weather Service Display } \\
\text { Version 1.64a (release } \\
\text { date: June 2011) }\end{array}$ & $\begin{array}{l}\text { (FEMA, 2003; Jarvinen } \\
\text { and Lawrence, 1985; } \\
\text { Jelesnianski, Chen, and } \\
\text { Shaffer, 1992) }\end{array}$ \\
\hline $\begin{array}{l}\text { Storm surge } \\
\text { interpolation tool }\end{array}$ & $\begin{array}{l}\text { Applied Science } \\
\text { Associates, Inc. }\end{array}$ & (Isaji and Knee, 2009) \\
\hline $\begin{array}{l}\text { SLAMM (Sea Level } \\
\text { Affecting Marshes } \\
\text { Model) }\end{array}$ & $\begin{array}{l}\text { Warren Pinnacle } \\
\text { Consulting, Inc. } \\
\text { Version } 6.0 .1 \text { beta }\end{array}$ & $\begin{array}{l}\text { (Warren Pinnacle } \\
\text { Consulting, 2010) }\end{array}$ \\
\hline Wetlands & $\begin{array}{l}\text { U.S. Fish and Wildlife } \\
\text { Service National } \\
\text { Wetlands Inventory }\end{array}$ & (USFWS, 2010) \\
\hline Upland Land Cover & $\begin{array}{l}\text { NOAA Coastal Change } \\
\text { Analysis Program }\end{array}$ & (NOAA, 2006) \\
\hline Local accretion rates & & $\begin{array}{l}\text { (Lynch, 2012; NPS, } \\
\text { 2009) }\end{array}$ \\
\hline
\end{tabular}


Table 2. Summary of sentinel site elevations. Standard error values account for variability of elevations among sentinel sites and do not account for measurement errors.

\begin{tabular}{|c|c|c|c|c|}
\hline $\begin{array}{l}\text { Study Area } \\
\text { (n) }\end{array}$ & $\begin{array}{c}\text { RTK GPS } \\
(\text { mean } \pm \text { SE m) }\end{array}$ & $\begin{array}{c}\text { LiDAR } \\
(\text { mean } \pm \text { SE m })\end{array}$ & $\begin{array}{c}\text { Absolute } \\
\text { Difference } \\
\text { (mean } \pm \text { SE m) }\end{array}$ & $\begin{array}{l}\text { Test of Mean } \\
\text { Differences }\end{array}$ \\
\hline $\begin{array}{l}\text { BOHA } \\
\text { (21) }\end{array}$ & $13.84 \pm 2.62$ & $12.82 \pm 2.52$ & $1.16 \pm 0.28$ & $\begin{array}{c}\text { Wilcoxon signed } \\
\text { rank test } \\
\mathrm{V}=202 \\
\mathrm{P}=0.0016\end{array}$ \\
\hline $\begin{array}{l}\text { CACO } \\
(63)\end{array}$ & $13.20 \pm 1.45$ & $12.02 \pm 1.46$ & $1.19 \pm 0.10$ & $\begin{array}{l}\text { Wilcoxon signed } \\
\text { rank test } \\
\mathrm{V}=1999\end{array}$ \\
\hline ASIS (34) & $1.39 \pm 0.07$ & $1.65 \pm 0.07$ & $0.29 \pm 0.04$ & $\begin{array}{c}\mathrm{P}<0.0001 \\
\text { Paired } \mathrm{t} \text { test } \\
\mathrm{t}=5.87, \mathrm{df}=33 \\
\mathrm{P}<0.001\end{array}$ \\
\hline
\end{tabular}


Table 3. Summary of LiDAR vertical accuracy assessment.

\begin{tabular}{cccc}
\hline \hline Study Area & $\begin{array}{c}\text { DEM Horizontal } \\
\text { Resolution }(\mathrm{m})\end{array}$ & $\begin{array}{c}\text { Control Points } \\
(\mathrm{n})\end{array}$ & $\begin{array}{c}\text { Vertical RMSE } \\
(\mathrm{m})\end{array}$ \\
BOHA & 1 & 21 & 1.65 \\
CACO & 1 & 35 & 0.53 \\
ASIS & 2.5 & 1,179 & 0.33 \\
\hline
\end{tabular}


Table 4. Storm surge heights predicted by SLOSH.

\begin{tabular}{ccc}
\hline $\begin{array}{c}\text { Storm } \\
\text { Class }\end{array}$ & CACO & ASIS \\
Surge Height $(\mathrm{m})$ & Surge Height $(\mathrm{m})$ \\
\hline Category 1 & $0.34-1.52$ & $0.43-1.77$ \\
Category 2 & $0.91-3.20$ & $0.73-3.02$ \\
Category 3 & $1.34-5.33$ & $2.56-4.30$ \\
Category 4 & $1.80-6.07$ & $4.15-5.55$ \\
\hline
\end{tabular}


Table 5. Extent of inundation (in hectares) within each study area under bath-tub model sea level rise scenarios and SLOSH hurricane scenarios.

\begin{tabular}{|c|c|c|c|c|c|c|c|}
\hline \multirow{2}{*}{$\begin{array}{l}\text { Study } \\
\text { Area }\end{array}$} & \multicolumn{3}{|c|}{ SLR Scenario } & \multicolumn{4}{|c|}{ Hurricane Class } \\
\hline & $0.6 \mathrm{~m}$ & $1 \mathrm{~m}$ & $2 \mathrm{~m}$ & Cat 1 & Cat 2 & Cat 3 & Cat 4 \\
\hline $\mathrm{CACO}$ & -- & 4,423 & 5,378 & 2,720 & 3,508 & 4,234 & 5,012 \\
\hline ASIS & 4,541 & 6,224 & 8,211 & 2,607 & 6,693 & 8,147 & 8,332 \\
\hline
\end{tabular}


Table 6. Mean ( \pm SE) probabilities of inundation at sentinel sites given bath-tub modeling scenario. Shown in parentheses is the number of sites where the probability of inundation exceeds 0.75 .

\begin{tabular}{cccc}
\hline \hline Study Area (n) & $0.6 \mathrm{~m}$ & $1 \mathrm{~m}$ & $2 \mathrm{~m}$ \\
\hline & & & \\
CACO (63) & -- & $0.064 \pm 0.029$ & $0.179 \pm 0.047$ \\
& & $(3)$ & $(11)$ \\
ASIS (34) & $0.130 \pm 0.51$ & $0.485 \pm 0.067$ & $0.950 \pm 0.035$ \\
& $(3)$ & $(11)$ & $(32)$ \\
\hline
\end{tabular}


Table 7. Mean $( \pm S E)$ probabilities of inundation at sentinel sites using the SLOSH storm scenarios. Shown in parentheses is the number of sites where the probability of inundation exceeds 0.75 .

\begin{tabular}{ccccc}
\hline \hline Study Area (n) & \multicolumn{4}{c}{ Hurricane Class } \\
& Category 1 & Category 2 & Category 3 & Category 4 \\
\hline \multirow{2}{*}{ CACO (63) } & $0.000 \pm 0.000$ & $0.013 \pm 0.012$ & $0.051 \pm 0.022$ & $0.114 \pm 0.034$ \\
& $(0)$ & $(1)$ & $(1)$ & $(5)$ \\
ASIS (34) & $0.162 \pm 0.047$ & $0.700 \pm 0.066$ & $0.980 \pm 0.009$ & $0.999 \pm 0.001$ \\
& $(2)$ & $(22)$ & $(34)$ & $(34)$ \\
& & & & \\
\hline
\end{tabular}


Table 8. CACO SLAMM conversion matrix. Numbers in parentheses indicate sentinel sites converted to each class in each inundation scenario ( $1 \mathrm{~m}$ and $2 \mathrm{~m}$ ).

\begin{tabular}{|c|c|c|c|c|c|c|c|c|c|}
\hline $\begin{array}{l}\text { Initial Category } \\
\text { (\# of sentinel sites) }\end{array}$ & \multicolumn{9}{|c|}{ Predicted Category ( $1 \mathrm{~m}, 2 \mathrm{~m}$ sea level scenarios) } \\
\hline $\begin{array}{l}\text { Dry Land } \\
\text { Developed (12) }\end{array}$ & $(12,12)$ & & & & & & & & \\
\hline $\begin{array}{l}\text { Dry Land } \\
\text { Undeveloped (46) }\end{array}$ & & $(40,34)$ & & $(5,10)$ & & $(1,1)$ & & & $(0,1)$ \\
\hline Nontidal Swamp (1) & & & $(1,0)$ & $(0,1)$ & & & & & \\
\hline $\begin{array}{l}\text { Transitional Marsh } \\
\text { (0) }\end{array}$ & & & & & & & & & \\
\hline Salt Marsh (0) & & & & & & & & & \\
\hline Estuarine Beach $(0)$ & & & & & & & & & \\
\hline Rocky Intertidal (2) & & & & & & & $(1,0)$ & & $(1,2)$ \\
\hline $\begin{array}{l}\text { Irregularly Flooded } \\
\text { Marsh (2) }\end{array}$ & & & & & $(1,2)$ & & & $(1,0)$ & \\
\hline Open Ocean (0) & & & & & & & & & \\
\hline
\end{tabular}


Table 9. ASIS SLAMM conversion matrix. Numbers in parentheses indicate sentinel sites converted to each class in each inundation scenario $(0.6 \mathrm{~m}, 1 \mathrm{~m}, 2 \mathrm{~m})$.

\begin{tabular}{|c|c|c|c|c|c|c|c|c|c|c|c|}
\hline \multirow{2}{*}{$\begin{array}{c}\text { Initial Category } \\
\text { (\# of sentinel } \\
\text { sites) }\end{array}$} & \multicolumn{11}{|c|}{ Predicted Category ( $0.6 \mathrm{~m}, 1 \mathrm{~m}, 2 \mathrm{~m}$ sea level scenarios) } \\
\hline & $\begin{array}{l}\text { Dry Land } \\
\text { Developed }\end{array}$ & $\begin{array}{c}\text { Dry Land } \\
\text { Undevelop } \\
\text { ed }\end{array}$ & $\begin{array}{l}\text { Inland } \\
\text { Fresh } \\
\text { Marsh }\end{array}$ & $\begin{array}{c}\text { Transitional } \\
\text { Marsh }\end{array}$ & $\begin{array}{c}\text { Salt } \\
\text { Marsh }\end{array}$ & $\begin{array}{c}\text { Estuarine } \\
\text { Beach }\end{array}$ & $\begin{array}{l}\text { Tidal } \\
\text { Flat }\end{array}$ & $\begin{array}{l}\text { Ocean } \\
\text { Beach }\end{array}$ & $\begin{array}{c}\text { Irregularly } \\
\text { Flooded } \\
\text { Marsh }\end{array}$ & $\begin{array}{c}\text { Estuarine } \\
\text { Open } \\
\text { Water }\end{array}$ & $\begin{array}{l}\text { Open } \\
\text { Ocean }\end{array}$ \\
\hline $\begin{array}{l}\text { Dry Land } \\
\text { Developed (1) }\end{array}$ & $(1,1,1)$ & & & & & & & & & & \\
\hline $\begin{array}{l}\text { Dry Land } \\
\text { Undeveloped } \\
(24) \\
\end{array}$ & & $(8,2,0)$ & & $(7,7,9)$ & & $(0,1,1)$ & & $(8,11,3)$ & & & $(1,3,11)$ \\
\hline $\begin{array}{l}\text { Inland Fresh } \\
\text { Marsh (1) }\end{array}$ & & & $(1,1,0)$ & $(0,0,1)$ & & & & & & & \\
\hline $\begin{array}{l}\text { Transitional } \\
\text { Marsh (1) }\end{array}$ & & & & $(1,1,0)$ & $(0,0,1)$ & & & & & & \\
\hline Salt Marsh (1) & & & & & $(1,1,0)$ & & $(0,0,1)$ & & & & \\
\hline $\begin{array}{l}\text { Estuarine Beach } \\
\text { (1) }\end{array}$ & & & & & & $(1,1,0)$ & & & & $(0,0,1)$ & \\
\hline Tidal Flat (0) & & & & & & & & & & & \\
\hline Ocean Beach (1) & & & & & & & & & & & $(1,1,1)$ \\
\hline $\begin{array}{l}\text { Irregularly } \\
\text { Flooded Marsh } \\
\text { (4) }\end{array}$ & & & & & $(0,1,4)$ & & & & $(4,3,0)$ & & \\
\hline $\begin{array}{l}\text { Estuarine Open } \\
\text { Water (0) }\end{array}$ & & & & & & & & & & & \\
\hline Open Ocean (0) & & & & & & & & & & & \\
\hline
\end{tabular}


Table 10. CACO SLAMM conversion matrix with aggregated classes. Numbers in parentheses indicate sentinel sites converted to each class in each inundation scenario ( $1 \mathrm{~m}$ and $2 \mathrm{~m}$ ).

\begin{tabular}{|c|c|c|c|c|c|}
\hline $\begin{array}{c}\text { Initial } \\
\text { Category } \\
\text { (number of } \\
\text { sentinel } \\
\text { sites) }\end{array}$ & \multicolumn{5}{|c|}{ Predicted Category (1 m, 2 m sea level scenarios) } \\
\hline & Upland & $\begin{array}{c}\text { Forested } \\
\text { Wetland }\end{array}$ & Marsh & Beach & Open Water \\
\hline Upland (58) & $(52,46)$ & $(5,10)$ & & $(1,1)$ & $(0,1)$ \\
\hline $\begin{array}{c}\text { Forested } \\
\text { Wetland (1) }\end{array}$ & & $(1,1)$ & & & \\
\hline Marsh (2) & & & $(2,2)$ & & \\
\hline Beach & & & & & $(2,2)$ \\
\hline $\begin{array}{c}\text { Open Water } \\
(2)\end{array}$ & & & & & \\
\hline
\end{tabular}


Table 11. ASIS SLAMM conversion matrix with aggregated classes. Numbers in parentheses indicate sentinel sites converted to each class in each inundation scenario $(0.6 \mathrm{~m}, 1 \mathrm{~m}, 2 \mathrm{~m})$.

\begin{tabular}{|c|c|c|c|c|c|}
\hline $\begin{array}{c}\text { Initial } \\
\begin{array}{c}\text { Category } \\
\text { (number of } \\
\text { sentinel } \\
\text { sites) }\end{array}\end{array}$ & \multicolumn{5}{|c|}{ Predicted Category $(0.6 \mathrm{~m}, 1 \mathrm{~m}, 2 \mathrm{~m}$ sea level scenarios) } \\
\hline & Upland & $\begin{array}{c}\text { Forested } \\
\text { Wetland }\end{array}$ & Marsh & Beach & Open Water \\
\hline Upland (25) & $(9,3,1)$ & $(7,7,9)$ & & $(8,12,4)$ & $(1,3,11)$ \\
\hline $\begin{array}{c}\text { Forested } \\
\text { Wetland (2) }\end{array}$ & & $(2,2,1)$ & $(0,0,1)$ & & \\
\hline Marsh (5) & & & $(5,5,4)$ & & $(0,0,1)$ \\
\hline Beach (2) & & & & $(1,1,0)$ & $(1,1,2)$ \\
\hline Open Water & & & & & \\
\hline
\end{tabular}


Table 12. Principal components analysis of risk variables. Class loadings for the first three principal components are provided for each variable.

\begin{tabular}{lcccccc}
\hline \multicolumn{1}{c}{ Variable } & \multicolumn{7}{c}{ CACO } & & & ASIS & \\
& PC1 & PC2 & PC3 & PC1 & PC2 & PC3 \\
& & & & & & \\
GPS Elevation & 0.37 & 0.23 & 0.09 & 0.42 & 0.09 & -0.11 \\
C1_Depth & -0.37 & -0.23 & -0.09 & -0.39 & -0.04 & 0.10 \\
C2_Depth & -0.37 & -0.23 & -0.09 & -0.33 & 0.46 & -0.04 \\
C3_Depth & -0.37 & -0.23 & -0.08 & -0.40 & 0.20 & -0.10 \\
C4_Depth & -0.37 & -0.23 & -0.08 & -0.37 & -0.18 & -0.06 \\
Prob_60cm & -0.19 & 0.47 & -0.53 & -0.28 & -0.36 & -0.45 \\
Prob_1m & -0.23 & 0.49 & -0.34 & -0.33 & -0.25 & -0.20 \\
Prob_2m & -0.27 & 0.30 & 0.41 & -0.28 & 0.17 & 0.74 \\
SLAMM_60cm & -- & -- & -- & -0.04 & -0.70 & 0.42 \\
SLAMM_1m & -0.25 & 0.39 & 0.23 & -- & -- & -- \\
SLAMM_2m & -0.29 & 0.17 & 0.59 & -- & -- & - \\
& & & & & & \\
Percent Variation & $62.7 \%$ & $23.5 \%$ & $7.3 \%$ & $57.8 \%$ & $16.4 \%$ & $9.8 \%$ \\
Explained & & & & & & \\
Cumulative & $62.7 \%$ & $86.3 \%$ & $93.6 \%$ & $57.8 \%$ & $74.2 \%$ & $84.0 \%$ \\
Variation & & & & & & \\
\hline
\end{tabular}


Table 13. Inundation Index class and corresponding PC1 raw scores. PC score classes were based on quintile categories of the data.

\begin{tabular}{ccc}
\hline Inundation Index Class & CACO & ASIS \\
\hline Very Likely & -5.54 to -1.87 & -5.55 to -1.74 \\
Likely & -1.87 to -0.56 & -1.74 to -0.43 \\
As Likely as Not & -0.56 to 0.60 & -0.43 to 0.45 \\
Unlikely & 0.60 to 1.62 & 0.45 to 1.66 \\
Very Unlikely & 1.62 to 5.56 & 1.66 to 6.00 \\
\hline
\end{tabular}




\section{LITERATURE CITED}

Ashton, A.D.; Donnelly, J.P., and Evans, R.L., 2008. A discussion of the potential impacts of climate change on the shorelines of the Northeastern USA. Mitigation and Adaptation Strategies for Global Change, 13, 719-743.

August, P. V., 1983. The effects of habitat complexity and heterogeneity in structuring tropical mammal communities. Ecology, 64, 1495-1507.

Bender, M.A.; Knutson, T.R.; Tuleya, R.E.; Sirutis, J.J.; Vecchi, G.A.; Garner, S.T., and Held, I.M., 2010. Modeled impact of anthropogenic warming on the frequency of intense Atlantic hurricanes. Science, 327, 454-458.

Bonisteel, J.M.; Nayegandi, A.; Wright, C.W.; Brock, J.C., and Nagle, D.B., 2009. Experimental Advanced Airborne Research Lidar (EAARL) Data Processing Manual. U.S. Geological Survey, Open File Report 2009-1078, 38p.

Bonisteel-Cormier, J.M.; Nayegandhi, A.; Brock, J.C.; Wright, C.W.; Nagle, D.B.; Klipp, E.S.; Vivekanandan, S.; Fredericks, X., and Stevens, S., 2010. EAARL coastal topography and imagery-Assateague Island National Seashore, Maryland and Virginia, post-Nor'Ida, 2009. U.S. Geological Survey, Data Series 559, 1 DVD.

Brock, J.C.; Wright, C.W.; Patterson, M.; Nayegandhi, A., and Travers, L.J., 2007. EAARL Topography- Cape Cod National Seashore, 2005. U.S. Geological Survey, Open File Report 2007-1375.

Brown, I., 2006. Modelling future landscape change on coastal floodplains using a rule-based GIS. Environmental Modelling and Software, 21, 1479-1490.

Cazenave, A. and Nerem, R.S., 2004. Present-day sea level change: observations and causes. Review of Geophysics, 42.

CCSP, 2009. Coastal Sensitivity to Sea-Level Rise: A Focus on the Mid-Atlantic Region. A report by the U.S. Climate Change Science Program and the Subcommittee on Global Change Research. Washington, DC: U.S. Environmental Protection Agency, 320 p.

Church, J.A. and White, N.J., 2006. A 20th century acceleration in global sea-level rise. Geophysical Research Letters, 33.

Engelhart, S.E.; Peltier, W.R., and Horton, B.P., 2011. Holocene relative sea-level changes and glacial isostatic adjustment of the U.S. Atlantic coast. Geology, 39(8), 751-754. 
ESRI (Environmental Systems Research Institute), 2011. ArcGIS Desktop: Release 10. Redlands, CA: Environmental Systems Research Institute.

FEMA (Federal Emergency Management Agency), 2003. SLOSH Display Training. URL: http://www.fema.gov/pdf/plan/prevent/nhp/slosh_display_training.pdf; accessed August 2010.

Gao, J., 2007. Towards accurate determination of surface height using modern geoinformatic methods: possibilities and limitations. Progress in Physical Geography, 31, 591-605.

Gesch, D.B., 2007. The National Elevation Dataset. In: Maune, D. (ed), Digital Elevation Model Technologies and Applications: The DEM Users Manual 2nd edition. Bethesda, Maryland: American Society for Photogrammetry and Remote Sensing, pp. 99-118.

Gesch, D.B., 2009. Analysis of lidar elevation data for improved identification and delineation of lands vulnerable to sea-level rise. In: Brock, J.C. and Purkis, S.J. (eds.), The Emerging Role of Lidar Remote Sensing in Coastal Research and Resource Management. Journal of Coastal Research, Special Issue No. 53, pp. 49-58.

Gutierrez, B.T.; Williams, S.J., and Thieler, E.R., 2007. Potential for shoreline changes due to sea-level rise along the U.S. Mid-Atlantic region. U.S. Geological Survey, Open-File Report 2007-1278, 30p.

Hammar-Klose, E.S.; Pendleton, E.A.; Thieler, E.R., and Williams, S.J., 2003. Coastal Vulnerability Assessment of Cape Cod National Seashore (CACO) to SeaLevel Rise. Reston, Virginia: U.S. Geological Survey, Open-File Report 02$233,23 \mathrm{p}$.

Harvey, N. and Nicholls, R., 2008. Global sea-level rise and coastal vulnerability. Sustainability Science, 3, 5-7.

Hennecke, W.G. and Cowell, P.J., 2000. GIS modeling of impacts of an accelerated rate of sea-level rise on coastal inlets and deeply embayed shorelines. Environmental Geosciences, 7, 137-148.

Hu, A.; Meehl, G.A.; Han, W., and Yin, J., 2009. Transient response of the MOC and climate to potential melting of the Greenland Ice Sheet in the 21 st century. Geophysical Research Letters, 36.

IPCC (Intergovernmental Panel on Climate Change), 2007. Climate Change 2007: The Physical Science Basis. Contribution of Working Group I to the Fourth Assessment Report (AR4). New York: Cambridge University Press. 
Irish, J.L.; Frey, A.E.; Rosati, J.D.; Olivera, F.; Dunkin, L.M.; Kaihatu, J.M.; Ferreira, C.M., and Edge, B.L., 2010. Potential implications of global warming and barrier island degradation on future hurricane inundation, property damages, and population impacted. Ocean and Coastal Management, 53, 645-657.

Isaji, T. and Knee, K., 2009. Interpolation tool for handling storm surge spatial variability for inundation simulation. South Kingstown, RI: Applied Science Associates, Inc.

Jarvinen, B.R. and Lawrence, M.B., 1985. An evaluation of the SLOSH storm surge model. Bulletin of the American Meteorological Society, 66: 1408-1411.

Jelesnianski, C. P.; Chen, J., and Shaffer, W.A., 1992. SLOSH: Sea, lake, and overland surges from hurricanes. Silver Spring, Maryland: National Oceanic and Atmospheric Administration, Technical Report NWS 48, 71p.

Kirshen, P.; Watson, C.; Douglas, E.; Gontz, A.; Lee, J., and Tian, Y., 2008. Coastal flooding in the Northeastern United States due to climate change. Mitigation and Adaptation Strategies for Global Change, 13, 437-451.

Kirwan, M.L. and Guntenspergen, G.R., 2009. Accelerated sea-level rise - a response to Craft et al. Frontiers in Ecology and the Environment, 7, 126-127.

Lewis, M.; Horsburgh, K.; Bates, P., and Smith, R., 2011. Quantifying the uncertainty in future coastal flood risk estimates for the U.K. Journal of Coastal Research, 27(5), 870-881.

Lin, N.; Emanuel, K.A.; Smith, J.A., and Vanmarcke E., 2010. Risk assessment of hurricane storm surge for New York City. Journal of Geophysical Research 115: D18121.

Lynch, J. Interviewed by: Murdukhayeva, A. January 4, 2012.

Marindin, H.L., 1891. On the changes in the shoreline and anchorage areas of Cape Cod (or Provincetown Harbor) as shown by a comparison of surveys made between 1835, 1867, and 1890. U.S. Coast and Geodetic Survey Report.

MassGIS (Commonwealth of Massachusetts Information Technology Division, Office of Geographic Information), 2005. MassGIS LIDAR for Metropolitan Boston.

McInnes, K.L.; Walsh, K.J.E.; Hubbert, G.D., and Beer, T., 2003. Impact of sea-level rise and storm surge on a coastal community. Natural Hazards, 30, 187-207.

Mcleod, E.; Poulter, B.; Hinkel, J.; Reyes, E., and Salm, R., 2010. Sea-level rise impact models and environmental conservation: A review of models and their applications. Ocean and Coastal Management, 53(9), 507-517. 
Murdukhayeva, A.; Bradley, M.; Shaw, N.; LaBash, C.; Grybas, H.; Davis, T.; August, P.V.; Smith T., and Duhaime, R., 2012. Using high accuracy geodesy to assess risk from climate change in coastal National parks. In: Weber, S., ed. Rethinking Protected Areas in a Changing World: Proceedings of the 2011 George Wright Society Biennial Conference on Parks, Protected Areas, and Cultural Sites. Hancock, Michigan: The George Wright Society, 252-259.

NGS (National Geodetic Survey), 2011. The NGS Geoid Page. URL: http://www.ngs.noaa.gov/GEOID/; accessed March 4, 2012.

NOAA (National Oceanic and Atmospheric Administration), 2006. The Coastal Change Analysis Program (C-CAP) Regional Land Cover.

NOAA (National Oceanic and Atmospheric Administration), 2007. National Oceanic and Atmospheric Administration, Center for Operational Oceanographic Products and Services. Tides and Currents. URL: http://tidesandcurrents.noaa.gov; accessed December 29, 2011.

NOAA (National Oceanic and Atmospheric Administration), 2010. Technical Considerations for Use of Geospatial Data in Sea Level Change Mapping and Assessment. Silver Spring, Maryland: National Oceanic and Atmospheric Administration, NOS 2010-01, 141p.

NOAA (National Oceanic and Atmospheric Administration), 2011. VDatum. URL: http://vdatum.noaa.gov; accessed March 5, 2012.

NOAA CSC (National Oceanic and Atmospheric Administration Coastal Services Center), 2010a. Mapping Inundation Uncertainty. Charleston, South Carolina: NOAA Coastal Services Center, 10p.

NOAA CSC (National Oceanic and Atmospheric Administration Coastal Services Center), 2010b. Lidar Data Collected in Marshes: Its Error and Application for Sea Level Rise Modeling. Charleston, South Carolina: NOAA Coastal Services Center, 22p.

NPS (National Park Service), 2009. Cape Cod National Seashore Resource Brief: Salt Marsh Elevation. URL: http://www.nps.gov/caco/naturescience/upload/MMsaltmarshelevationfactshee t_corrected-2.pdf; accessed December 29, 2011.

Ott, R.L. and M. Longnecker. 2010. An Introduction to Statistical Methods and Data Analysis. Belmont, California: Brooks/Cole, 1273p.

Overpeck, J.T. and Weiss, J.L., 2009. Projections of future sea level rise becoming more dire. Proceedings of the National Academy of Sciences of the United States of America, 106, 21461-21462. 
Pendleton, E.A.; Williams, S.J., and Thieler, E.R., 2004. Coastal Vulnerability Assessment of Assateague Island National Seashore (ASIS) to Sea-Level Rise. Woods Hole, Massachusetts: U.S. Geological Survey, Open File Report 20041020, 20p.

Pfeffer, W.T.; Harper, J.T., and O'Neel, S., 2008. Kinematic constraints on glacier contributions to 21st-century sea level rise. Science, 321, 1340-1343.

Poulter, B. and Halpin, P.N., 2008. Raster modeling of coastal flooding from sea-level rise. International Journal of Geographic Information Science, 22, 167-182.

R Development Core Team, 2011. R: A language and environment for statistical computing. Vienna, Austria: R Foundation for Statistical Computing.

Rahmstorf, S., 2007. A semi-empirical approach to projecting future sea-level rise. Science, 315, 368-370.

Scarborough, R. W., 2009. Application of the Sea Level Rise Affecting Marsh Model (SLAMM) Using High Resolution Data at Prime Hook National Wildlife Refuge. Dover, Delaware: Delaware Department of Natural Resources and Environmental Control, 62p.

Scawthorn, C.; Blais, N.; Seligson, H.; Tate, E.; Mifflin, E.; Thomas, W.; Murphy, J., and Jones, C., 2006a. HAZUS-MH Flood Loss Estimation Methodology. I: Overview and Flood Hazard Characterization. Natural Hazards Review, 7, 6071.

Scawthorn, C.; Flores, P.; Blais, N.; Seligson, H.; Tate, E.; Chang, S.; Mifflin, E.; Thomas, W.; Murphy, J.; Jones, C., and Lawrence, M., 2006b. HAZUS-MH Flood Loss Estimation Methodology. II. Damage and Loss Assessment. Natural Hazards Review, 7, 72-81.

Sto. Domingo, N.D.; Paludan, B.; Madsen, H.; Hansen, F., and Mark, O., 2010. Climate Change and Storm Surges: Assessing Impacts on Your Coastal City Through Mike Flood Modeling. Denmark: DHI Water, Environment and Health Report, 11p.

Tamisiea, M.E. and Mitrovica, J.X., 2011. The moving boundaries of sea level change: understanding the origins of geographic variability. Oceanography, $24,24-39$.

USFWS (U. S. Fish and Wildlife Service), 2010. National Wetlands Inventory. URL: http://www.fws.gov/wetlands; accessed December 29, 2011. 
Van Drie, R.; Milevski, P., and Simon, M., 2010. Assessment of sea level rise and climate change impacts using ANUGA. 19th NSW Coastal Conference (Bateman's Bay), 15p.

Vermeer, M. and Rahmstorf, S., 2009. Global sea level linked to global temperature. Proceedings of the National Academy of Sciences 106, 21527-21532.

Warren Pinnacle Consulting, 2010. SLAMM: Sea Level Affecting Marshes Model. URL: http://warrenpinnacle.com/prof/SLAMM; accessed January 2012.

Yin, J.; Schlesinger, M., and Stouffer, R., 2009. Model projections of rapid sea level rise on the northeast coast of the United States. Nature Geoscience, 2, 262266. 


\section{APPENDIX 1}

Factors contributing to sea level rise in the Northeast

\section{Introduction}

An increase in the rate of sea level rise is one of the most serious potential impacts of climate change (IPCC, 2007). Global (or eustatic) sea level rise is caused by the thermal expansion of ocean water due to rising global temperatures, and an increased output of water from land-based sources, such as melting glaciers. The rate of eustatic sea level rise has accelerated since the $19^{\text {th }}$ century (Donnelly et al., 2004; Church and White, 2006; Kemp et al., 2011). However, the rate of relative (or local) sea level rise varies regionally. Relative sea level is the change measured with respect to a specific vertical datum relative to the land (CCSP, 2009) and can be increasing or decreasing over time. It is the combination of eustatic sea level and local land movement. Each coastal region experiences different rates of subsidence or isostatic rebound from glacial melting after the last Ice Age (Tamisiea and Mitrovica, 2011). Other local effects contributing to relative sea level include soil compaction, fluid withdrawal and shallow subsidence in marshes (Cahoon and Guntenspergen, 2010). On the Northeast Atlantic Coast, many regions are experiencing subsidence from glacial isostatic adjustment effects (Engelhart, Peltier, and Horton, 2011) with rates (as

measured by mean sea level trends at tide gauges) generally increasing towards the south (Table A1.1).

\section{Major Challenges in Sea Level Rise Risk Assessment}

\section{Uncertainty in Projections}


The largest challenge in performing sea level rise inundation risk assessments is the great uncertainty regarding future expected sea level. The most widely cited estimates of sea level for the year 2100 come from the Intergovernmental Panel on Climate Change (IPCC)'s Fourth Assessment. The report projects 0.26 to $0.59 \mathrm{~m}$ of global sea level rise by 2100 under the "business as usual" greenhouse gas emissions scenario (IPCC, 2007). This represents a conservative estimate because it does not consider either increased greenhouse gas emissions over the next century, or changes in ocean volume caused by increased flow of Greenland and Antarctic ice (Overpeck and Weiss, 2009).

Many sea level rise scientists have attempted to model contributions of ice melt to sea level, but great uncertainties regarding ice sheet flow dynamics remain. Vermeer and Rahmstorf (2009) use a semi-empirical method that links global sealevel variations to global mean temperature on time scales of decades to centuries and project a global sea level rise of 1.13 to $1.79 \mathrm{~m}$ by 2100 . By considering probable melting scenarios for the Greenland and Antarctic ice sheets, Pfeffer, Harper and O’Neel (2008) predict a sea level rise range of 0.80 to $2.0 \mathrm{~m}$ by 2100 .

Determining the rate and acceleration of local sea level rise is complicated by the small number of long-term tide gauges (Houston and Dean, 2011), strong spatial variation in the distribution of melting ocean waters (Cazenave and Nerem, 2004), and seasonal-to-decadal temporal variation (Church, White, and Arblaster, 2005). However, many climate scientists agree that the Northeast coast is particularly vulnerable to higher rates of relative sea level rise (Frumhoff et al., 2007). Along with high rates of subsidence, the northeast North American coast faces a predicted 
increase in dynamic sea level due to Atlantic meridional overturning circulation slowdown in the $21^{\text {st }}$ century (Hu et al., 2009). Global climate models predict ocean surface warming would shut down deep convection in the Labrador Sea and slow the sub-polar gyre, and these impacts would result in dynamic, or ocean circulation driven, sea level rise in the Northeast region (Yin, Schlesinger, and Stouffer, 2009).

Given this combination of influences and the numerous estimates of future global sea level rise rates, downscaling global projections to a local level is challenging. To address this difficulty, risk assessments must model multiple scenarios in order to gain an understanding of the range of potential impacts. In this assessment, I chose $0.6 \mathrm{~m}, 1 \mathrm{~m}$ and $2 \mathrm{~m}$ of relative sea level rise as plausible scenarios for 2100 in the Northeast.

\section{Uncertainty in Elevation Mapping}

Sea level rise inundation risk assessments are further complicated by the lack of high resolution topographic data. Detailed maps of elevation are necessary to determine which areas fall within elevations that may be inundated under various sea level rise scenarios. The U.S. Geological Survey (USGS) National Elevation Dataset contains the most accurate readily available digital elevation models for the United States. For much of the Northeast coast, the highest resolution data available are derived from 5 or 10 foot contour USGS topographic maps and are accurate to $\pm 2.4 \mathrm{~m}$ (Gesch, 2009). A more recent source of elevation data is from LiDAR (Light Detection and Ranging) acquired from a plane-mounted laser sensor that emits pulses of light energy at the ground, and is accurate to $0.15-1 \mathrm{~m}$ (Gao, 2007). The accuracy associated with elevation data limits the sea level rise increment that can be modeled, 
and determines the range of uncertainty associated with inundation predictions (Figure A1.1) The National Park Service Inventory and Monitoring Program maintains and manages LiDAR data for coastal parks in the Northeast. At present, there are some LiDAR elevation data for every park in the URI-NPS Monumentation study (Murdukhayeva et al., 2012) except Acadia. However, the coverage of these data is sometimes incomplete or in need of updating (Skidds, 2011). For example, there are no LiDAR data for 22 of the 34 Boston Harbor Islands, and coverage of Cape Cod is incomplete.

In this assessment, LiDAR data were used, when available, to model risk at sentinel sites, natural, cultural or infrastructural resources of importance to park managers. They were supplemented by real time kinematic global positioning system (RTK GPS) data collected using survey-grade devices (Trimble Engineering and Construction Group) at sentinel site locations. Survey, or geodetic, grade GPS devices are a promising tool in studying sea level rise and storm surge impacts. These devices are capable of measuring elevation at accuracies of up to 1 to 2 centimeters in the vertical dimension and have the ability to quickly calculate a reference position with highly accurate $\mathrm{x}, \mathrm{y}$, and $\mathrm{z}$ positional information. Using these two sources of elevation data, we can make an informed assessment of probability of inundation risk at each site.

Another source of uncertainty in inundation mapping is the conversion of elevations from an orthometric vertical datum to a tidally referenced datum. This conversion must be performed in each study region. Elevations are typically reported in the North American Vertical Datum of 1988 (NAVD88). This is an orthometric 
datum established in 1991 that represents height above the primary tidal bench mark in Rimouski, Quebec. It does not represent the upper extent of high tide. For inundation mapping, we are interested in sea level extents above mean higher high water (MHHW). MHHW is the average of the higher high water height of each tidal day observed over a national tidal datum epoch, i.e., 19 year measurement period adopted by the National Ocean Service (Hicks, 1999). Standardizing sea level heights relative to MHHW provides the maximum extent of flooding during normal high tides. VDatum is used to convert elevation values from NAVD88 to MHHW over large regions. VDatum is a tool developed by NOAA's National Geodetic Survey, Office of Coast Survey, and Center for Operational Oceanographic Products and Services to vertically transform geospatial data among a variety of tidal, orthometric and ellipsoidal vertical datums (NOS). This conversion has associated errors which have been calculated on a regional basis (Table A1.2)

\section{Conclusion}

Given these limitations and uncertainties, it is important that inundation modelers and mappers use their tools and models properly, select sea level rise scenarios appropriate to the available data accuracy, and most importantly, interpret resulting maps and products with an understanding of the possible inaccuracies involved. In the future, collection of higher accuracy regional elevation data and installation of more coastal tide gauges would be great assets to assessing coastal risk from sea level rise and helping in resource management prioritization. 
Figure A1.1 Mapping $1 \mathrm{~m}$ of sea level rise on land, adapted from Gesch (2009). Digital elevation models with different vertical RMSEs result in inundation zones with different $95 \%$ confidence intervals and estimates of uncertainty.

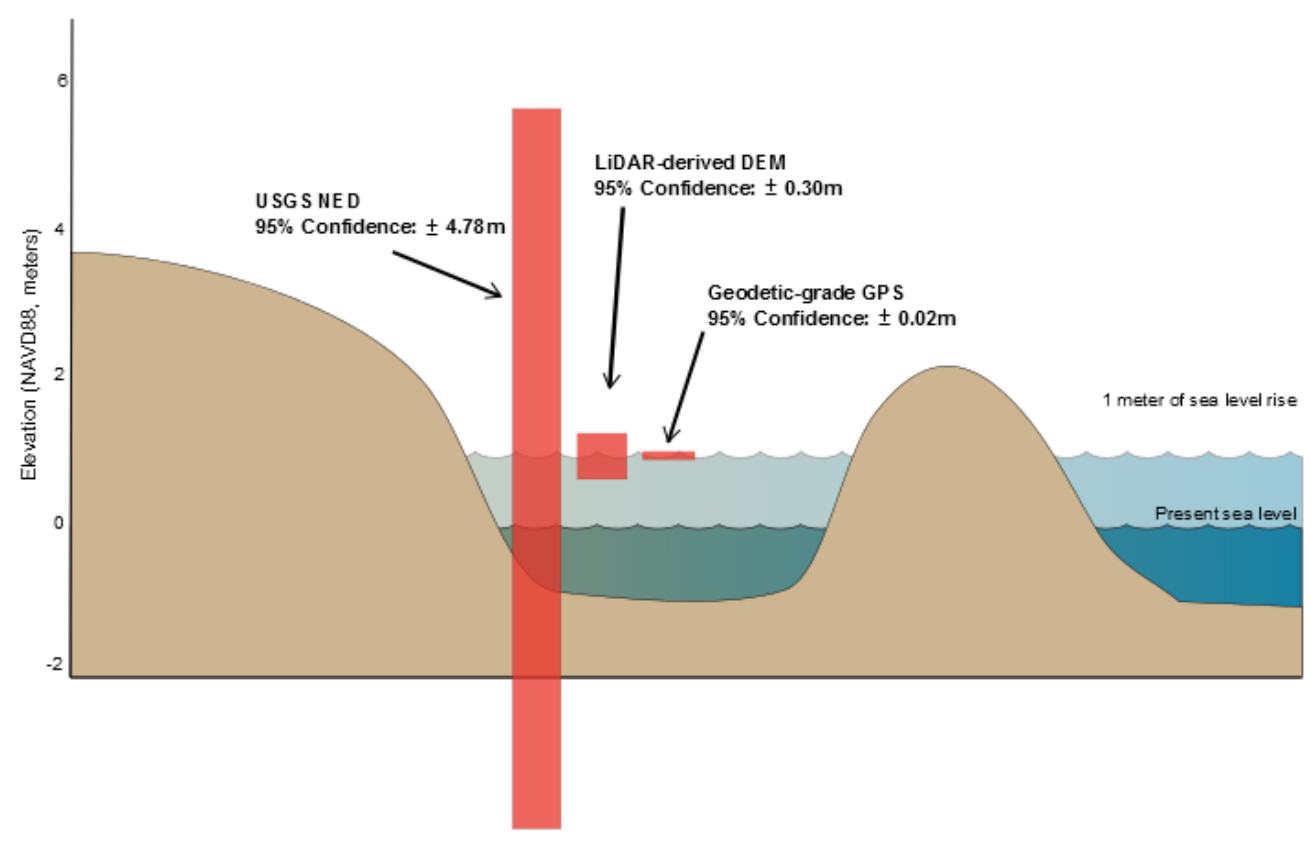


Table A1.1 Sea level trends measured at tide ganges near NPS study sites (NOAA, 2007).

\begin{tabular}{llcc}
\hline \multicolumn{1}{c}{ National Park } & \multicolumn{1}{c}{ Tide Gauge } & Time & $\begin{array}{c}\text { Mean Sea Level } \\
\text { Trend (mm/year) }\end{array}$ \\
\hline Acadia & Bar Harbor, ME & $1947-2006$ & $2.04 \pm 0.26$ \\
Boston Harbor Islands & Boston, MA & $1921-2006$ & $2.63 \pm 0.18$ \\
Cape Cod & Woods Hole, MA & $1932-2006$ & $2.61 \pm 0.20$ \\
& Nantucket Island, & $1965-2006$ & $2.95 \pm 0.46$ \\
MA & & \\
Eleway & Sandy Hook, NJ & $1932-2006$ & $3.90 \pm 0.25$ \\
Liberty & The Battery, NY & $1856-2006$ & $2.77 \pm 0.09$ \\
Fire Island & & & \\
Assateague & Montauk, NY & $1947-2006$ & $2.78 \pm 0.32$ \\
George Washington & Ocean City, MD & $1975-2006$ & $5.48 \pm 1.67$ \\
Birthplace & Lewisetta, VA & $1974-2006$ & $4.97 \pm 1.04$ \\
Colonial & & & \\
& Kiptopeke, VA & $1951-2006$ & $3.48 \pm 0.42$ \\
& Sewells Point, VA & $1927-2006$ & $4.44 \pm 0.27$ \\
\hline
\end{tabular}


Table A1.2 Errors associated with orthometric-tidal datum conversions.

\begin{tabular}{llc}
\hline \multicolumn{1}{c}{ Region } & \multicolumn{1}{c}{ Parks } & $\begin{array}{c}\text { Maximum Cumulative } \\
\text { Uncertainty }\end{array}$ \\
\hline $\begin{array}{l}\text { Maine, New Hampshire, } \\
\text { Massachusetts }\end{array}$ & ACAD, BOHA, CACO & $13.2 \mathrm{~cm}$ \\
$\begin{array}{l}\text { New York, New Jersey, } \\
\text { Connecticut }\end{array}$ & GATE, ELIS, STLI & $9.3 \mathrm{~cm}$ \\
$\begin{array}{l}\text { New York: Great South } \\
\text { Bay }\end{array}$ & FIIS & $11.4 \mathrm{~cm}$ \\
$\begin{array}{l}\text { Virginia, Maryland, } \\
\text { Delaware }\end{array}$ & ASIS & $14.0 \mathrm{~cm}$ \\
$\begin{array}{l}\text { Virginia/Maryland: } \\
\text { Chesapeake Bay }\end{array}$ & GEWA, COLO & $10.2 \mathrm{~cm}$ \\
\end{tabular}




\section{LITERATURE CITED}

Cahoon, D.R. and Guntenspergen, G.R., 2010. Climate change, sea-level rise, and coastal wetlands. National Wetlands Newsletter 32, 8-12.

Cazenave, A. and Nerem, R.S., 2004. Present-day sea level change: observations and causes. Review of Geophysics 42.

CCSP, 2009. Coastal Sensitivity to Sea-Level Rise: A Focus on the Mid-Atlantic Region. A report by the U.S. Climate Change Science Program and the Subcommittee on Global Change Research. Washington, DC: U.S. Environmental Protection Agency, 320 p.

Church, J.A. and White, N.J., 2006. A 20th century acceleration in global sea-level rise. Geophysical Research Letters 33.

Church, J.A.; White, N.J., and Arblaster, J.M., 2005. Significant decadal-scale impact of volcanic eruptions on sea level and ocean heat content. Nature 438, 74-77.

Donnelly, J.P.; Cleary, P.; Newby, P., and Ettinger, R., 2004. Coupling instrumental and geological records of sea-level change: evidence from southern New England of an increase in the rate of sea-level rise in the late 19th century. Geophysical Research Letters 31.

Engelhart, S.E.; Peltier, W.R., and Horton, B.P., 2011. Holocene relative sea-level changes and glacial isostatic adjustment of the U.S. Atlantic coast. Geology 24(2), 70-79.

Frumhoff, P.C.; McCarthy, J.J.; Melillo, J.M.; Moser, S.C., and Wuebbles, D.J., 2007. Confronting Climate Change in the U.S. Northeast: Science, Impacts, and Solutions. Synthesis report of the Northeast Climate Impacts Assessment (NECIA). Cambridge, Massachusetts: Union of Concerned Scientists, 160p.

Gao, J., 2007. Towards accurate determination of surface height using modern geoinformatic methods: possibilities and limitations. Progress in Physical Geography 31, 591-605.

Gesch, D.B., 2009. Analysis of lidar elevation data for improved identification and delineation of lands vulnerable to sea-level rise. In: Brock, J.C. and Purkis, S.J. (eds.), The Emerging Role of Lidar Remote Sensing in Coastal Research and Resource Management. Journal of Coastal Research, Special Issue No. 53, pp. 49-58.

Hicks, S.D., 1999. Tide and Current Glossary. Silver Spring, Maryland: National Oceanic and Atmospheric Administration, National Ocean Service, 34p. 
Houston, J.R. and Dean, R.G., 2011. Sea-level acceleration based on U.S. tide gauges and extensions of previous global-gauge analyses. Journal of Coastal Research, 27(3), 409-417.

Hu, A.; Meehl, G.A.; Han, W., and Yin, J., 2009. Transient response of the MOC and climate to potential melting of the Greenland Ice Sheet in the 21st century. Geophysical Research Letters 36.

IPCC (Intergovernmental Panel on Climate Change), 2007. Climate Change 2007: The Physical Science Basis. Contribution of Working Group I to the Fourth Assessment Report (AR4). New York: Cambridge University Press.

Kemp, A.C.; Horton, B.P.; Donnelly, J.P.; Mann, M.E.; Vermeer, M., and Rahmstorf, S., 2011. Climate related to sea-level variations over the past two millennia. Proceedings of the National Academy of Sciences.

Murdukhayeva, A.; Bradley, M.; Shaw, N.; LaBash, C.; Grybas, H.; Davis, T.; August, P.V.; Smith T., and Duhaime, R., 2012. Using high accuracy geodesy to assess risk from climate change in coastal National parks. In: Weber, S., ed. Rethinking Protected Areas in a Changing World: Proceedings of the 2011 George Wright Society Biennial Conference on Parks, Protected Areas, and Cultural Sites. Hancock, Michigan: The George Wright Society, 252-259.

NOAA (National Oceanic and Atmospheric Administration), 2007. National Oceanic and Atmospheric Administration, Center for Operational Oceanographic Products and Services. Tides and Currents. URL: http://tidesandcurrents.noaa.gov; accessed September 1, 2011.

NOS (National Ocean Service). URL: http://vdatum.noaa.gov; accessed September 1, 2011.

Overpeck, J.T. and Weiss, J.L., 2009. Projections of future sea level rise becoming more dire. Proceedings of the National Academy of Sciences 106, 2146121462.

Pfeffer, W.T.; Harper, J.T., and O’Neel, S., 2008. Kinematic constraints on glacier contributions to 21st-century sea level rise. Science 321, 1340-1343.

Skidds, D. Interviewed by: Murdukhayeva, A. March 30, 2011.

Tamisiea, M.E. and Mitrovica, J.X., 2011. The moving boundaries of sea level change: Understanding the origins of geographic variability. Oceanography 24, 24-39. 
Trimble Engineering and Construction Group. URL:

http://trl.trimble.com/docushare/dsweb/Get/Document-140079/022543-

079J_TrimbleR8GNSS_DS_1109_LR.pdf; accessed April 18, 2011.

Vermeer, M. and Rahmstorf, S., 2009. Global sea level linked to global temperature. Proceedings of the National Academy of Sciences 106, 21527-21532.

Yin, J.; Schlesinger, M.E., and Stouffer, R.J., 2009. Model projections of rapid sea level rise on the northeast coast of the United States. Nature Geoscience 2, 262-266. 


\section{APPENDIX 2}

A review of sea level rise and storm surge inundation models and their applications

\section{Introduction}

There are many methods for modeling sea level rise and storm surge impacts, ranging from simple estimates of inundation based on available elevation data and coarse regional predictions of storm flooding to complex site-specific, hydrodynamic and hydraulic models. This review highlights the results of a literature search and assessment that was conducted to select the appropriate modeling methodology for the National Park Service (NPS) Monumentation project. I consulted many sources, including a variety of scientific journals, conference proceedings papers, NOAA and USGS technical reports, and NOAA Coastal Services Center experts. I examined a variety of programs that model sea level rise inundation and storm surge flooding following extreme weather events. If a model was publicly available at no cost, I performed an evaluation run using off-the-shelf technical documentation as a guide. I assessed models based on their ability to predict inundation risk on a regional scale at National Park study sites, to be reapplied with updated elevation data, and to be used in a single-user computing environment. This review of methods is not comprehensive; other useful models and methods do exist. Readers interested in the history of coastal storm inundation modeling from the mid-1950s to present day are directed to Massey et al. (2007)'s review, and those interested in sea level rise models and their applications to biological conservation are directed to Mcleod et al. (2010)'s review. 


\section{Levels of Complexity}

\section{Zero-Dimensional}

There are varying levels of complexity for flood inundation models, ranging from zero-dimensional (0D) to three-dimensional (3D). The most basic models are 0D and do not include any physical laws. OD models overlay the determined high water level with a digital elevation model to create a water surface. This is a popular method and is also referred to as "linear superposition" or "bath-tub modeling." It is relatively inexpensive to run and can coarsely approximate coastal vulnerability for a variety of scenarios. The results can be incorporated into a Geographic Information System (GIS) to calculate potentially inundated areas.

The bath-tub approach provides quick analyses of vulnerability at regional and global scales. The analysis is done in a raster environment. The approach identifies all cells with elevations lower than the projected sea level rise as vulnerable to inundation. A more sophisticated approach incorporates connectivity and requires that the cells identified as vulnerable have elevations lower than the projected sea level rise and are adjacent to the ocean or to other inundated cells (Poulter and Halpin, 2008). The approach is limited: it does not incorporate flood defenses, or recognize coastal processes such as wetland accretion. It tends to result in large overestimations of flood extents. Like all modeling approaches, it is limited by uncertainties in sea level projections and elevation data, and lack of data on the feedback of physical and social systems (e.g. sediment transport regimes and human adaptation responses). However, due to its simplicity and efficiency, the approach has been applied in a variety of studies. Weiss, Overpeck, and Strauss (2011) used it to identify areas at risk from sea 
level rise of 1 to $6 \mathrm{~m}$ in 20 coastal cities in the United States, and Demirkesen, Evrendilek, and Berberoglu (2008) used it to identify vulnerable low-lying coastal areas in Turkey.

\section{1-Dimensional, 2-Dimensional, and 3-Dimensional}

The next level of hydrodynamic inundation modeling is one-dimensional (1D). The one-dimensional (1D) flood inundation models solve the 1D Saint Venant equations to simulate water flowing through a breach and the flow propagation velocity (Marshman, 2010). This approach is appropriate for relatively flat systems with a primary channel, but inappropriate for situations where the study area experiences significant or complex wetting and drying processes or in areas where there is significant slope. Examples of 1D models are HEC-RAS and DYNLET. The two-dimensional (2D) modeling method solves the 2D shallow water equations. It considers flood propagation in both horizontal directions (parallel and perpendicular to primary channel), surface roughness and flow characteristics. The 1D and 2D methods are often combined in vulnerability analyses (e.g. Martinelli, Zanuttigh, and Corbau, 2010). The 3D modeling method solves a variety of complex algorithms (Burg, Thorenz, and Blum, 2009) and requires large data storage and significant investment in time and resources. I researched several examples of 2D and 3D models.

\section{Model Evaluations}

\section{LISFLOOD-FP}

LISFLOOD-FP is a two-dimensional hydrodynamic model developed by Bates and De Roo (2000) at the University of Bristol. It was developed primarily for river basin flooding, but later versions incorporated coastal flooding scenarios. The model 
predicts water depths over a raster grid and simulates the propagation of flood waves over fluvial, coastal and estuarine floodplains. At the time of my research (November 2010), the program code was not available for download. Validation studies for coastal flooding applications had accuracies ranging from 54-91\% (Bates, 2009). I decided not to pursue the use of this model for the NPS study because the coastal component did not seem developed, the program code was not available, and most of the users and support team were concentrated in the UK.

\section{ANUGA Hydrodynamic Model}

The ANUGA hydrodynamic inundation modeling tool was first developed by the Australian National University (ANU) in the 1990s. The most recent version was redesigned and redeveloped in 2004 at Geoscience Australia (GA). The 2D model uses a finite-volume method to solve shallow water wave equations (GA, 2010). The model was developed in order to simulate the behavior of water flow from coastal hazards such as tsunami and flash floods in built environments. One of the most important capabilities of the model is its ability to model the process of wetting and drying as water enters and leaves an area. This makes it suitable for modeling water flow on a beach or dry land and around structures such as buildings. The free, open-source model is written in Python and available for download at SourceForge (GA, 2010). The user inputs the bathymetry and topography for the study area, the initial water level and boundary conditions such as tide or any forcing terms that may drive the system such as wind stress or atmospheric pressure (Nielsen et al., 2005). The study area is represented by a mesh of triangular cells. The model was developed primarily for modeling effects of tsunami and was validated with a wave tank simulation of the 
1993 Okushiri Island Tsunami (Nielsen et al., 2005). Developers suggest using the model for detailed inundation modeling of small sections (Van Drie, Milevski, and Simon, 2010). ANUGA is being developed to incorporate riverine flooding and storm surge flooding scenarios. The model has only been tested at a few locations and the current release (Version 1.2.1) is still in the development and debugging process. I downloaded and installed the software from the website and found that the documentation and forums were unhelpful in understanding implementation. I also found that I did not have enough technical knowledge of Python to debug some of the issues.

\section{MIKE by DHI Software Series}

The Mike Software series was developed by DHI (Danish Hydraulic Institute) Water and Environment in Denmark over 20 years ago. The products are used around the world by water scientists and engineers. For coastal flood mapping, the firm suggests using a combination of MIKE 21 and MIKE FLOOD. MIKE-21 is a two dimensional, finite difference hydrodynamic flow model used to simulate physical, chemical and biological processes in coastal and marine areas. MIKE FLOOD is a toolbox attachment for flood modeling and mapping. The software catalog states that the attachment has a range of tools that can perform flood assessments, hazard mapping, risk analysis, contingency planning, and integrated urban drainage, river and coastal flood assessments (DHI, 2011). The product is capable of modeling flooding of coastal cities and infrastructure, and inundation in low-lying areas. The model outputs are accepted by the US Federal Emergency Management Agency (FEMA) for use in the National Flood Insurance Program. The program is easily integrated with 
ArcGIS and was used in Sweden to simulate riverine flooding and obtain flood information for emergency planning (Yang and Rystedt, 2002).The program is available for $\$ 57,400$ and there is a university discount for student researchers (DHI, 2011). The prohibitive nature of the price also led me to remove it from consideration for the NPS study. However, the model seems to be a suitable tool for engineers and could be appropriate for other research endeavors.

\section{ADCIRC}

The ADCIRC (Advanced Circulation) Model was developed as a joint project between the University of Notre Dame and University of North Carolina Chapel Hill (Luettich, Westernick, and Scheffner, 1992; Westerink et al., 1992). The 2D and 3D components of the program solve equations for motion for a moving fluid on a rotating earth using traditional hydrostatic pressure and Boussinesq approximations. The software is used to model tides and wind driven circulation, analyze hurricane storm surge and flooding, and conduct dredging and material disposal studies and larval transport studies. FEMA uses ADCIRC to develop FIRMs (Flood Insurance Rate Maps). ADCIRC has been used to model storm surge for New Orleans, Louisiana (Westerink et al., 2008), the Chesapeake Bay (Shen, Gong, and Wang, 2005; Shen, Gong, and Wang, 2006) and the northeastern Gulf of Mexico (Chen, Wang, and Tawes, 2008). These studies have demonstrated the high accuracy of the ADCIRC model in simulating coastal storm surge (Lin et al., 2010). The program is extremely complex, run on over 100 computers simultaneously at the UNC campus and cannot be used by me for the NPS study. While the software is too computer intensive for the NPS study, it could be an appropriate approach for other projects. 


\section{HAZUS-MH}

The HAZUS-MH (Multi-Hazards) software was developed by ABS Consulting as a hazard model to be used with ArcGIS. It is the modeling program used by FEMA to estimate potential losses from natural disasters. The program models earthquakes, hurricane winds and floods, and estimates the physical, economic and social impacts of disasters. It identifies high-risk areas, and illustrates spatial relationships between populations and permanently fixed geographic assets and resources (FEMA, 2010). The model's flood component uses a flood loss estimation methodology consisting of two modules. The first module is a hazard analysis module that uses characteristics such as frequency, discharge and ground elevation to estimate flood depth, flood elevation and flow velocity. The second module is the loss estimation module that calculates the physical damage and economic loss using census block and default building inventory data (Scawthorn et al., 2006a; Scawthorn et al., 2006b). The user can edit this database or incorporate locally available flood information using the Flood Information Tool (FIT) in the software.

I decided not to use HAZUS-MH for the NPS study. Damon (2010) notes that the coastal flooding component of the program is least developed, and that editing the default data with recent relevant data (new flood boundaries, buildings inventory, land use, etc.) is a tedious process. The great strength of this program is its ability to calculate damages, and would be more appropriate for coastal urban areas, not natural resources in protected parks.

\section{SLAMM}


SLAMM (Sea Level Affecting Marshes Model) was first developed in the mid1980s with funding from the EPA to simulate the dominant processes of wetland conversions and shoreline modifications during long-term sea level rise. In the late 1980s, the model's second version SLAMM2 was used to simulate $20 \%$ of the coast of the contiguous US for the EPA Report to Congress on the potential effects of global climate change. Model development continued into the 1990s and 2000s. The most recent version of the model, SLAMM6, was developed and funded by the Nature Conservancy (Warren Pinnacle Consulting, 2010). The data requirements are a digital elevation model, slope file, a wetlands map, and specific parameters about the study area (tidal range, sedimentation rates, map dates). The user selects one or more sea level scenarios and the program calculates water elevation at a particular location and uses decision tree rules to compute the habitat response.

There is great debate surrounding this model and its outputs. One limitation of the model is that it is sensitive to the time-step selected. Regardless of the sea level elevation change chosen, SLAMM will only convert habitats once per time step and only to the next category defined. For example, a cell that begins as dry land, but becomes inundated due to SLR, will convert as follows: Dry Land » Transitional Marsh » Salt Marsh » Tidal Flat » Open Water (Hancock, 2009). Selecting a smaller time step (ex. 2 years) can address this issue, but is computationally demanding. The modeling approach also does not account for infrequent events that influence wetland vertical development such as storms and floods. Furthermore, there is no way to quantitatively determine the uncertainty associated with a SLAMM prediction. Another concern is that SLAMM does not consider increased rates of accretion due to 
sea level rise, a feedback mechanism that can be incorporated into numerical models. Many wetland scientists recommend use of the elevation capital technique (Cahoon and Guntenspergen, 2010) and the use of numerical coastal models that predict the response of sea level through non-linear feedback mechanisms (Kirwan and Guntenspergen, 2009) for local studies.

\section{SLOSH}

The SLOSH (Sea, Land and Overland Surges from Hurricanes) model was developed by the National Weather Service (NWS) to predict storm surge heights resulting from historical, hypothetical or predicted hurricanes (FEMA, 2003). It is the primary model used by the Federal Emergency Management Agency (FEMA), the National Oceanographic and Atmospheric Administration (NOAA) and the US Army Corps of Engineers (USACE). The SLOSH user selects one of several "basins," geographic regions with known values of topography and bathymetry. Most topographic data are obtained from the U.S. Geological Survey (USGS), but other sources are utilized in small areas where available and necessary. Bathymetry data are obtained from the National Geophysical Data Center (NGDC). The user also selects a hurricane track, identified by its pressure, radius of maximum winds, location, direction and speed. The model accounts for astronomical tides by allowing the user to specify initial tide level. The model solves a set of equations and outputs water surface

elevations in each grid cell based on storm characteristics. The equations are derived from Newtonian equations of motion and the continuity equation, applied to a rotating fluid with a free surface (Jarvinen and Lawrence, 1985; Jelesnianski, Chen, and 
Shaffer, 1992). The output can be used to estimate potential surge and flooding for a given hurricane category, forward speed and direction (FEMA, 2003).

Storm surge heights can be viewed in two ways. For each storm category, forward speed and direction of motion, the model creates a MEOW, Maximum Envelope of Water, which is the set of the highest surge values at each grid location. For some basins there are over 80 generated MEOWs. The model also creates a MOM, Maximum of MEOWs. It is the composite of maximum storm surge height for all hurricanes of a given category, regardless of forward speed, landfall direction and landfall location. There are only 4-5 MOMs per basin, i.e. one per storm category. MOMs represent a worst case scenario of surge inundation, and therefore should not be used for emergency planning (Marcy, 2011). The reported accuracy for the SLOSH model is plus or minus $20 \%$ of the peak storm surge. If the model calculates a peak storm surge of 10 feet for the event, the observed peak ranges from 8 to 12 feet. The accuracy was accessed by looking at surge measurements (primarily high water marks) from past hurricanes. The model does not account for rainfall amounts, river flow or wind-driven waves (FEMA, 2003). SLOSH has been utilized in many inundation vulnerability assessments (Lin et al., 2010; Stockdon and Thompson, 2007).

\section{Coastal Vulnerability Indices}

The Coastal Vulnerability Index (CVI) was developed by the USGS Coastal and Marine Geology Program to determine the relative risk that physical changes will occur as sea level rises (Thieler, Williams, and Hammar-Klose, 1999). The index is a simple classification of the relative vulnerability of shoreline segments. The index is 
based on six criteria: tidal range, wave height, coastal slope, geomorphology, shoreline erosion rate and historical relative sea level rise rate, gathered from a variety of sources. The approach yields a relative ranking of possibility that future physical change will occur.

\section{Decisions}

For my inundation risk assessment of National Park study sites, I chose to utilize the bath-tub modeling approach and address some of its limitations, following recommendations from NOAA (2010). For example, I incorporated an orthometrictidal datum conversion to ensure that projected sea level rise was added to a tidal surface and not to heights from the orthometric datum. I also performed a calculation of uncertainty in inundation predictions that incorporated known errors from the elevation dataset, tide gauges and vertical conversion software. When reporting predicted areas of inundation, I only reported areas that were connected to the ocean surface or other flooded areas. Areas that may be protected by land barriers or other features were not included.

I decided to use SLAMM because it is a large scale landscape model that simulates general trends over large areas. I understand its limitations and that the output is not suitable for site-specific research problems. Scaling down results to the local level is not feasible with any degree of certainty, because so many variables are unknown. However, I believe it can provide us with some level of understanding to discuss overall vulnerability and shape management goals. The model has great potential to be modified and improved as more knowledge about wetland processes is acquired. 
For storm surge modeling and risk assessment, I chose to use output from the SLOSH model. I used the MOM (Maximum of MEOW) heights from the Providence/Boston and Ocean City basins for Saffir-Simpson Category 1-4 Hurricanes (Figure A2.1). The horizontal resolution of the output data varied in each study area; it ranged from 1.3 to $1.9 \mathrm{~km}$ in the Cape Cod area, from 0.4 to $0.7 \mathrm{~km}$ in the Boston area, and from 1.0 to $2.3 \mathrm{~km}$ in the Assateague Island area. The model is widely used in the risk mapping community and has benefited from National Weather Service's consistent updates of parameters following large storm events. The output was processed with the help of Kelly Knee, a water resources engineer, at Applied Science Associates, Inc. I used their "Inundation Toolbox" (Isaji and Knee, 2009) to model and map flooding results. 
Figure A2.1 SLOSH Storm Basins. A. Providence/Boston Basin; B. Ocean City Basin

A.

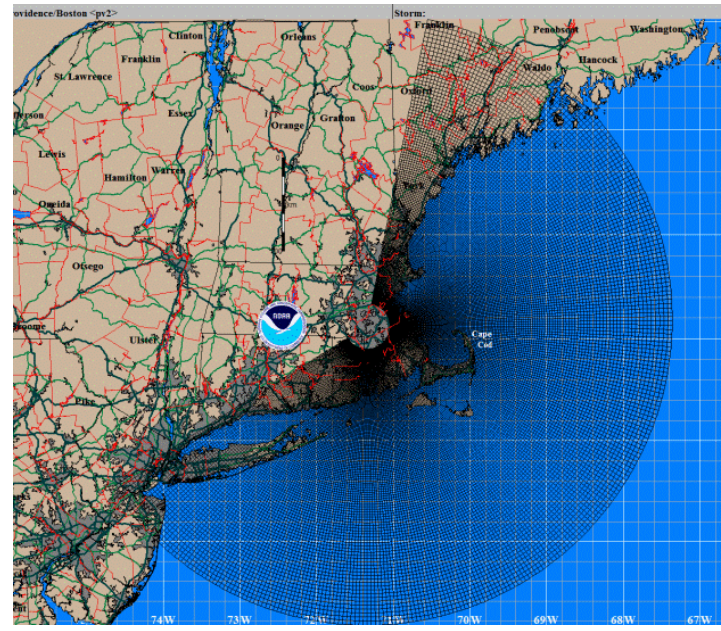

B.

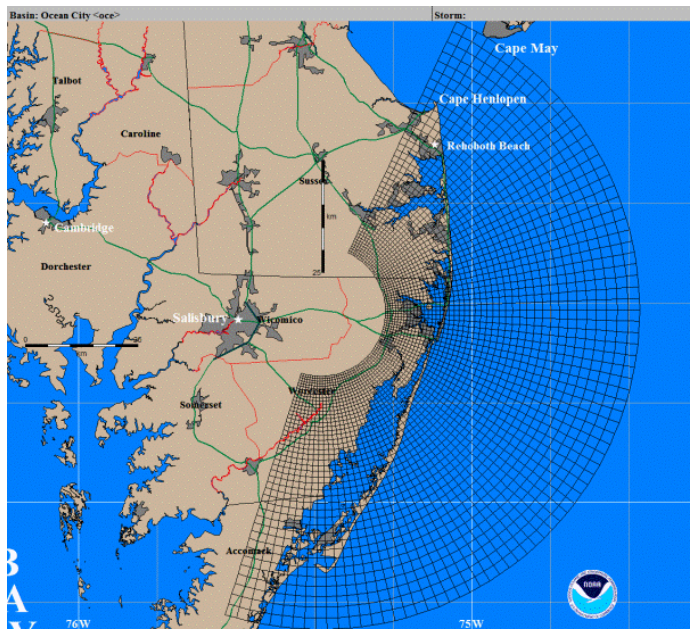




\section{LITERATURE CITED}

Bates, P., 2009. LISFLOOD-FP. URL:

http://www.bris.ac.uk/geography/research/hydrology/models/lisflood; accessed November 2010.

Bates, P. D. and De Roo, A.P.J., 2000. A simple raster-based model for floodplain inundation. Journal of Hydrology, 236, 54-77.

Burg, S.; Thorenz, F., and Blum, H., 2009. Coastal flood inundation modelling for North Sea lowlands. In: Samuels, P., Huntington, S., Allsop, W. and Harrop, J. (eds.), Flood Risk Management: Research and Practice, Taylor and Francis Group, London, 1367-1376.

Cahoon, D.R. and Guntenspergen, G.R., 2010. Climate change, sea-level rise, and coastal wetlands. National Wetlands Newsletter, 32, 8-12.

Chen, Q.; Wang, L., and Tawes R., 2008. Hydrodynamic response of northeastern Gulf of Mexico to hurricanes. Estuaries and Coasts, 31(6), 1098-1116.

Damon, C. Interviewed by: Murdukhayeva, A. September 1, 2010.

Demirkesen, A.C.; Evrendilek, F., and Berberoglu, S., 2008. Quantifying coastal inundation vulnerability of Turkey to sea-level rise. Environmental Monitoring and Assessment, 138, 101-106.

DHI (Danish Hydraulic Institute), 2011. Mike by DHI: Modelling the world of water, 2011 Software Catalog. URL: http://www.mike-by-dhi.com/; accessed August 2010.

FEMA (Federal Emergency Management Agency), 2003. SLOSH Display Training. URL: http://www.fema.gov/pdf/plan/prevent/nhp/slosh_display_training.pdf; accessed August 2010.

FEMA (Federal Emergency Management Agency), 2010. HAZUS-MH. URL: http://www.fema.gov/plan/prevent/hazus; accessed September 2010.

GA (Geoscience Australia), 2010. ANUGA on Source Forge. URL: http://sourceforge.net/projects/anuga; accessed August 2010.

Hancock, R., 2009. Using GIS and simulation modeling to assess the impact of sea level rise on coastal salt marshes. Kingston, Rhode Island: University of Rhode Island, Master's Major Paper, 52p. 
Isaji, T. and Knee, K., 2009. Interpolation tool for handling storm surge spatial variability for inundation simulation. South Kingstown, RI: Applied Science Associates, Inc.

Jarvinen, B.R. and Lawrence, M.B., 1985. An evaluation of the SLOSH storm surge model. Bulletin of the American Meteorological Society, 66: 1408-1411.

Jelesnianski, C. P.; Chen, J., and Shaffer, W.A., 1992. SLOSH: Sea, lake, and overland surges from hurricanes. Silver Spring, Maryland: National Oceanic and Atmospheric Administration, Technical Report NWS 48, 71p.

Kirwan, M.L. and Guntenspergen, G.R., 2009. Accelerated sea-level rise - a response to Craft et al. Frontiers in Ecology and the Environment, 7, 126-127.

Lin, N.; Emanuel, K.A.; Smith, J.A., and Vanmarcke E., 2010. Risk assessment of hurricane storm surge for New York City. Journal of Geophysical Research 115: D18121.

Luettich, R. A.; Westerink, J.J., and Scheffner, N.W., 1992. ADCIRC: An advanced three-dimensional circulation model for shelves, coasts, and estuaries. Report 1: Theory and methodology of ADCIRC-2DDI and ADCIRC-3DL. Vicksburg, Mississipi: U.S. Army Engineer Waterways Experiment Station. Technical Report DRP $\square 92-6$.

Marcy, D. Interviewed by: Murdukhayeva, A. March 13, 2011.

Martinelli, L.; Zanuttigh, B., and Corbau, C., 2010. Assessment of coastal flooding hazard along the Emilia Romagna littoral, IT. Coastal Engineering, 57, 10421058.

Massey, W.G.; Gangai, J.W.; Drei-Horgan, E., and Slover, K.J., 2007. History of coastal inundation models. Marine Technology Society Journal, 41, 7-17.

Marshman, S., 2010. Sensitivity testing the effect of breach representation on two contrasting coastal floodplains. Southampton, Great Britain: University of Southampton, Master's thesis, 104p.

Mcleod, E.; Poulter, B.; Hinkel, J.; Reyes, E., and Salm, R., 2010. Sea-level rise impact models and environmental conservation: A review of models and their applications. Ocean and Coastal Management, 53(9), 507-517.

Nielsen, O.; Roberts, S.; Gray, D.; McPherson, A., and Hitchman, A., 2005. Hydrodynamic modeling of coastal inundation. In: Zerger, A. and Argent, R.M. (eds.), MODSIM 2005 International Congress on Modeling and Simulation. Modeling and Simulation Society of Australia and New Zealand, pp. 518-523. 
NOAA (National Oceanic and Atmospheric Administration), 2010. Technical Considerations for Use of Geospatial Data in Sea Level Change Mapping and Assessment. Silver Spring, Maryland: National Oceanic and Atmospheric Administration, NOS 2010-01, 141p.

Poulter, B. and Halpin, P.N., 2008. Raster modeling of coastal flooding from sea-level rise. International Journal of Geographic Information Science, 22, 167-182.

Scawthorn, C.; Blais, N.; Seligson, H.; Tate, E.; Mifflin, E.; Thomas, W.; Murphy, J., and Jones, C., 2006a. HAZUS-MH Flood Loss Estimation Methodology. I: Overview and Flood Hazard Characterization. Natural Hazards Review, 7, 6071.

Scawthorn, C.; Flores, P.; Blais, N.; Seligson, H.; Tate, E.; Chang, S.; Mifflin, E.; Thomas, W.; Murphy, J.; Jones, C., and Lawrence, M., 2006b. HAZUS-MH Flood Loss Estimation Methodology. II. Damage and Loss Assessment. Natural Hazards Review, 7, 72-81.

Shen, J.; Gong, W., and Wang H., 2005. Simulation of Hurricane Isabel using the advanced circulation model (ADCIRC). In: Sellner, K.G. (ed), Hurricane Isabel in Perspective: Proceedings of a Chesapeake Bay Consortium Conference (Baltimore, MD), pp. 107-116.

Shen, J.; Gong, W., and Wang, H.V., 2006. Water level response to 1999 Hurricane Floyd in the Chesapeake Bay. Continental Shelf Research, 26, 2484-2502.

Stockdon, H.F. and Thompson D.M., 2007. Vulnerability of National Park Service beaches to inundation during a direct hurricane landfall: Fire Island National Seashore. USGS Open-File Report 2007-1389.

Thieler, E.R.; Williams, J., and Hammar-Klose, E., 2009. National Assessment of Coastal Vulnerability To Sea-Level Rise. URL: http://woodshole.er.usgs.gov/project-pages/cvi; accessed August 2010.

Van Drie, R.; Milevski, P., and Simon, M., 2010. Assessment of sea level rise and climate change impacts using ANUGA. 19th NSW Coastal Conference (Bateman's Bay), 15p.

Warren Pinnacle Consulting, 2010. SLAMM: Sea Level Affecting Marshes Model. URL: http://warrenpinnacle.com/prof/SLAMM; accessed January 2012.

Weiss, J.L.; Overpeck, J.T., and Strauss, B., 2011. Implications of recent sea level rise science for low-elevation areas in coastal cities of the conterminous U.S.A. Climatic Change, 105, 635-645. 
Westerink, J. J.; Luettich, R.A.; Blain, C.A., and Scheffner, N.W., 1992. ADCIRC: An advanced three-dimensional circulation model for shelves, coasts, and estuaries. Report 2: User's Manual for ADCIRC-2DDI. Vicksburg, Mississipi: U.S. Army Engineer Waterways Experiment Station. Technical Report $D R P \square 92-6$.

Westerink, J. J.; Feyen, J.C.; Atkinson, J.H.; Roberts, H.J.; Kubatko, E.J.; Luettich, R.A.; Dawson, C.; Powell, M.D.; Dunion, J.P., and Pourtuheri, H., 2008. A basin- to channel-scale unstructured grid hurricane storm surge model applied to southern Louisiana. Monthly Weather Review, 136, 833-864.

Yang, X. and Rystedt, B., 2002. Predicting flood inundation and risk using GIS and hydrodynamic model: a case study at Eskilstuna, Sweden. Indian Cartographer: 183-191. 


\section{APPENDIX 3}

Sentinel sites and their elevations.

Table A3.1 Boston Harbor Islands (BOHA) sentinel site elevations.

\begin{tabular}{|c|c|c|c|c|c|}
\hline ID & Description & $\begin{array}{c}\text { RTK GPS } \\
\text { Elevation }(\mathrm{m}) \\
\end{array}$ & $\begin{array}{c}\text { GPS Vertical } \\
\text { Error }(\mathrm{m})\end{array}$ & $\begin{array}{c}\text { LiDAR Elevation } \\
(\mathrm{m})\end{array}$ & Difference \\
\hline basin 1 & Moon Island - in basin & 0.574 & 0.072 & 0.562 & 0.012 \\
\hline basin 2 & Moon Island - in basin & 0.664 & 0.041 & 0.213 & 0.451 \\
\hline basin 3 & Moon Island - in basin & 0.925 & 0.039 & 0.683 & 0.242 \\
\hline basin 4 & Moon Island - edge of basin & 6.077 & 0.048 & 3.739 & 2.338 \\
\hline basin 5 & Moon Island - edge of basin & 6.105 & 0.044 & 5.602 & 0.503 \\
\hline basin 6 & Moon Island - edge of basin & 6.069 & 0.042 & 3.131 & 2.938 \\
\hline camp1 & Long Island - seawall & 2.700 & 0.030 & 2.134 & 0.566 \\
\hline camp2 & Long Island - dock & 5.653 & 0.033 & 1.258 & 4.395 \\
\hline cattail1 & Long Island - cattail marsh & 1.278 & 0.039 & 1.293 & -0.015 \\
\hline cattail2 & Long Island - cattail marsh & 1.216 & 0.029 & 1.506 & -0.290 \\
\hline cattail3 & Long Island - cattail marsh & 1.229 & 0.029 & 1.347 & -0.118 \\
\hline $\mathrm{ft}-\mathrm{cm} 1$ & Long Island cemetery & 22.934 & 0.067 & 23.904 & -0.970 \\
\hline $\mathrm{ft}-\mathrm{cm} 2$ & Long Island cemetery & 24.997 & 0.062 & 24.054 & 0.943 \\
\hline $\mathrm{ft}-\mathrm{cm} 3$ & Long Island cemetery & 24.718 & 0.059 & 23.637 & 1.081 \\
\hline $\mathrm{ft}-\mathrm{cm} 4$ & Long Island cemetery & 25.105 & 0.075 & 24.765 & 0.340 \\
\hline $\mathrm{ft}-\mathrm{lt}$ & Long Island light & 23.134 & 0.055 & 23.004 & 0.130 \\
\hline $\mathrm{ft}-1 \mathrm{t} 2$ & Long Island light & 23.308 & 0.055 & 23.371 & -0.063 \\
\hline $\mathrm{ft}-\mathrm{tbm} 1$ & Long Island TBM near light & 23.105 & 0.040 & 22.086 & 1.019 \\
\hline str & Long Island Ft Strong & 30.264 & 0.012 & 27.100 & 3.164 \\
\hline str-rm2 & Long Island Ft Strong RM2 & 30.286 & 0.014 & 28.343 & 1.943 \\
\hline str-rm3 & Backbone at Ft Strong & 30.290 & 0.013 & 27.406 & 2.884 \\
\hline
\end{tabular}


Table A3.2 Cape Cod National Seashore (CACO) sentinel site elevations.

\begin{tabular}{|c|c|c|c|c|c|}
\hline ID & Description & $\begin{array}{l}\text { RTK GPS } \\
\text { Elevation (m) }\end{array}$ & $\begin{array}{l}\text { GPS Vertical } \\
\text { Error }(\mathrm{m})\end{array}$ & $\begin{array}{l}\text { LiDAR Elevation } \\
(\mathrm{m})\end{array}$ & Difference \\
\hline bk1 & bike path near culvert & 4.800 & 0.037 & 3.352 & 1.448 \\
\hline bkpath & bike path near LBenn & 5.031 & 0.042 & 3.350 & 1.681 \\
\hline bkpath1 & water's edge near LBenn & 2.640 & 0.047 & 2.735 & -0.095 \\
\hline ccrt-tbm & nps mon & 16.776 & 0.012 & 15.988 & 0.788 \\
\hline culv1 & culvert right & 2.467 & 0.045 & 0.858 & 1.609 \\
\hline culv2 & culvert left & 2.457 & 0.041 & 1.585 & 0.872 \\
\hline dpw-reset & wellfleet & 16.588 & 0.011 & 15.387 & 1.201 \\
\hline egw36 & well egw36 & 17.651 & 0.087 & 16.240 & 1.411 \\
\hline egw37 & well wnw-17 top & 7.644 & 0.058 & 6.139 & 1.505 \\
\hline egw53g & well egw53 ground & 8.438 & 0.032 & 7.020 & 1.418 \\
\hline egw53t & well egw53 top & 9.144 & 0.032 & 7.020 & 2.124 \\
\hline fthill-spike & fort hill spike top & 7.592 & 0.028 & 5.248 & 2.344 \\
\hline fthill-spikebs & fort hill spike base & 6.185 & 0.031 & 5.146 & 1.039 \\
\hline hc-bh1 & herring cove bathhouse & 5.055 & 0.042 & 3.715 & 1.340 \\
\hline hc-bh2 & HC bathhouse pavement & 5.321 & 0.040 & 3.935 & 1.386 \\
\hline hcpk1 & HC parking lot & 4.377 & 0.043 & 3.039 & 1.338 \\
\hline hem-tbm & nps monumnet & 2.521 & 0.028 & 1.633 & 0.888 \\
\hline lthse1 & highlands lighthouse & 39.339 & 0.035 & 37.915 & 1.424 \\
\hline lthse 2 & well tsw106 & 23.061 & 0.032 & 21.158 & 1.903 \\
\hline mack1 & mack monument chatham & 14.514 & 0.015 & 13.175 & 1.339 \\
\hline marc-bath & marconi bathhouse & 15.393 & 0.014 & 14.243 & 1.150 \\
\hline
\end{tabular}




$\begin{array}{llllll}\text { marc-site } & \text { marconi site } & 30.112 & 0.025 & 28.675 & 1.437 \\ \text { naus-lh } & \text { Nauset light } & 18.670 & 0.018 & 16.862 & 1.808 \\ \text { naus-lot } & \text { Nauset beach lot } & 5.517 & 0.040 & 4.133 & 1.384 \\ \text { penniman } & \text { Penniman House } & 13.981 & 0.073 & 11.903 & 2.078 \\ \text { penniman1 } & \text { Penniman House 2 } & 14.208 & 0.046 & 12.375 & 1.833 \\ \text { pil-land1 } & \text { Pilgrim's landing mem } & 4.440 & 0.023 & 2.645 & 1.795 \\ \text { pvc-amp1 } & \text { PVC ampitheatre } & 19.900 & 0.028 & 18.397 & 1.503 \\ \text { pvc-deck1 } & \text { PVC deck } & 29.935 & 0.014 & 26.547 & 3.388 \\ \text { rm4 } & \text { Provincetown RM } & 28.902 & 0.012 & 27.032 & 1.870 \\ \text { rt6 } & \text { Route 6 adj to culvert } & 4.858 & 0.042 & 3.427 & 1.431 \\ \text { spvc-amp } & \text { SPVC ampitheatre } & 7.840 & 0.050 & 6.674 & 1.166 \\ \text { spvc-boat } & \text { SPVC boat } & 13.794 & 0.043 & 12.743 & 1.051 \\ \text { spvc-well-egw60 } & \text { well egw60 } & 13.591 & 0.036 & 12.064 & 1.527 \\ \text { stone-jetty1 } & \text { Stone Jetty top } & 4.015 & 0.027 & 2.081 & 1.934 \\ \text { stone-jetty2 } & \text { Stone Jetty mid } & 3.514 & 0.028 & 1.121 & 2.393 \\ \text { stone-jetty3 } & \text { Stone Jetty mid2 } & 3.266 & 0.030 & -1.025 & 4.291 \\ \text { wellpt5-gr } & \text { well pt5 ground } & 3.503 & 0.050 & 1.846 & 1.657 \\ \text { well-pt5 } & \text { well pt5 } & 4.033 & 0.034 & 1.846 & 2.187 \\ \text { wgw17bot } & \text { well wgw17 ground } & 7.243 & 0.034 & 6.139 & 1.104 \\ \text { whale } & \text { whale arch at penniman } & 12.535 & 0.054 & 11.433 & 1.102 \\ \text { caco2011cg } & \text { coast guard house } & 12.851 & 0.006 & 12.285 & 0.566 \\ \text { caco2011herr } & \text { herring river backbone } & 13.773 & 0.007 & 13.743 & 0.030 \\ \text { CACO2011MARC } & \text { Marconi headquarters } & 16.749 & 0.006 & 16.567 & 0.182 \\ \text { CACO2011MHWY } & \text { Truro-Ptown median rt 6 } & 2.968 & 0.007 & 3.060 & -0.092 \\ \text { caco2011nacl } & \text { north atlantic lab concrete } & 44.064 & 0.006 & 43.888 & 0.176\end{array}$




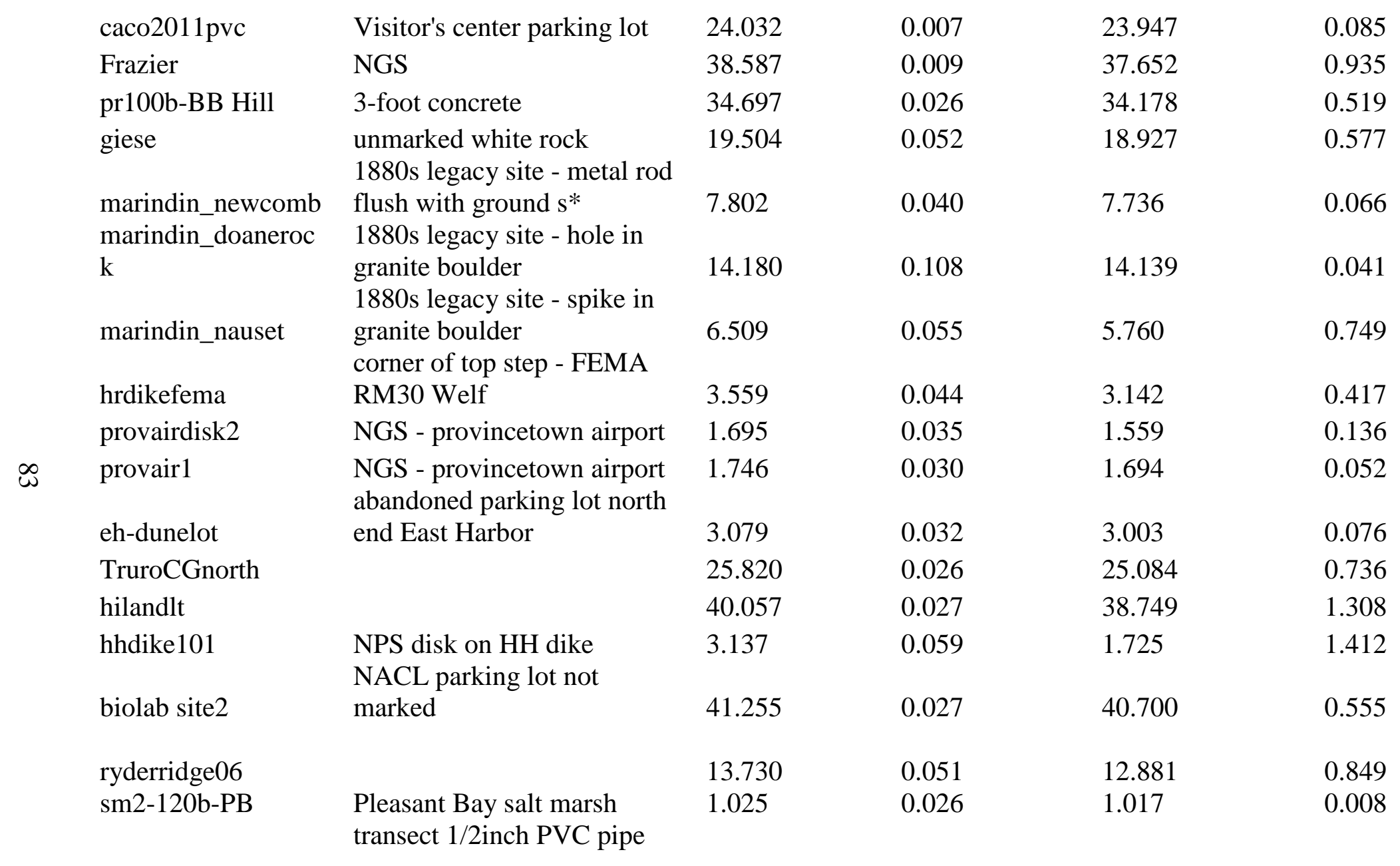


Table A3.3 Assateague Island National Seashore (ASIS) sentinel site elevations.

\begin{tabular}{|c|c|c|c|c|}
\hline ID & GPS Elevation (m) & $\begin{array}{l}\text { GPS Vertical } \\
\text { Error (m) }\end{array}$ & LiDAR Elevation (m) & Difference \\
\hline 2010ASIS001 & 1.702 & 0.007 & 1.888 & -0.186 \\
\hline 2010ASIS003 & 0.935 & 0.005 & 1.008 & -0.073 \\
\hline 2010ASIS004 & 0.765 & 0.006 & 0.885 & -0.120 \\
\hline 2010ASIS005 & 1.524 & 0.006 & 1.613 & -0.089 \\
\hline 2010ASIS006 & 2.599 & 0.004 & 2.788 & -0.189 \\
\hline 2010ASIS008 & 1.233 & 0.006 & 1.655 & -0.422 \\
\hline 2010ASIS009 & 1.4 & 0.002 & 1.866 & -0.466 \\
\hline 2010ASIS010R & 1.543 & 0.005 & 1.790 & -0.246 \\
\hline 2010ASISBAYR & 1.323 & 0.004 & 1.632 & -0.309 \\
\hline 2010ASISCH1 & 1.477 & 0.007 & 1.783 & -0.306 \\
\hline 2010ASISCH2 & 1.493 & 0.012 & 1.861 & -0.368 \\
\hline 2010ASISCH3R & 1.262 & 0.007 & 1.404 & -0.142 \\
\hline 2010ASISCH4 & 0.669 & 0.006 & 1.184 & -0.515 \\
\hline 2011ASIS002 & 1.372 & 0.006 & 1.516 & -0.144 \\
\hline FW0527_G466 & 2.279 & Fixed & 1.887 & 0.392 \\
\hline GPS1 & 1.316 & 0.007 & 1.662 & -0.346 \\
\hline GPS2 & 1.716 & 0.014 & 2.549 & -0.833 \\
\hline GPS3 & 1.28 & 0.007 & 1.220 & 0.060 \\
\hline GPS4 & 0.988 & 0.007 & 1.539 & -0.551 \\
\hline gps6 & 1.306 & 0.008 & 1.604 & -0.298 \\
\hline gps9 & 1.041 & 0.008 & 1.922 & -0.881 \\
\hline gps10 & 1.347 & 0.008 & 1.897 & -0.550 \\
\hline gps11 & 0.858 & 0.008 & 1.443 & -0.585 \\
\hline
\end{tabular}




$\begin{array}{lllll}\text { gps12 } & 1.43 & 0.007 & 1.627 & -0.197 \\ \text { gps13 } & 0.575 & 0.015 & 0.793 & -0.218 \\ \text { gps14 } & 1.305 & 0.004 & 1.571 & -0.266 \\ \text { gps15 } & 1.607 & 0.005 & 1.796 & -0.189 \\ \text { gps16 } & 1.236 & 0.008 & 1.371 & -0.135 \\ \text { GPS17 } & 1.024 & 0.004 & 1.230 & -0.206 \\ \text { HU1023_B141 } & 1.605 & \text { Fixed } & 1.500 & 0.105 \\ \text { HU1024_C141 } & 1.69 & \text { Fixed } & 2.084 & -0.394 \\ \text { HU1026_M141 } & 1.949 & \text { Fixed } & 2.052 & -0.103 \\ \text { HU1027_E141 } & 1.923 & \text { Fixed } & 1.896 & 0.027 \\ \text { HU1583_NB2 } & 1.446 & \text { Fixed } & 1.442 & 0.004 \\ \end{array}$

$\stackrel{\infty}{\leftrightarrow}$

Fixed $=0.000001 \mathrm{~m}$

GPS Errors reported here are from a network adjustment report and represent errors relative to each point.

There is an error of $0.02 \mathrm{~m}$ associated with those points that are "fixed," so $0.02 \mathrm{~m}$ was added to each error value to represent cumulative error at a point. 


\section{APPENDIX 4}

Table A4.1 Probabilities of inundation and overall inundation index (PC1) at sentinel sites.

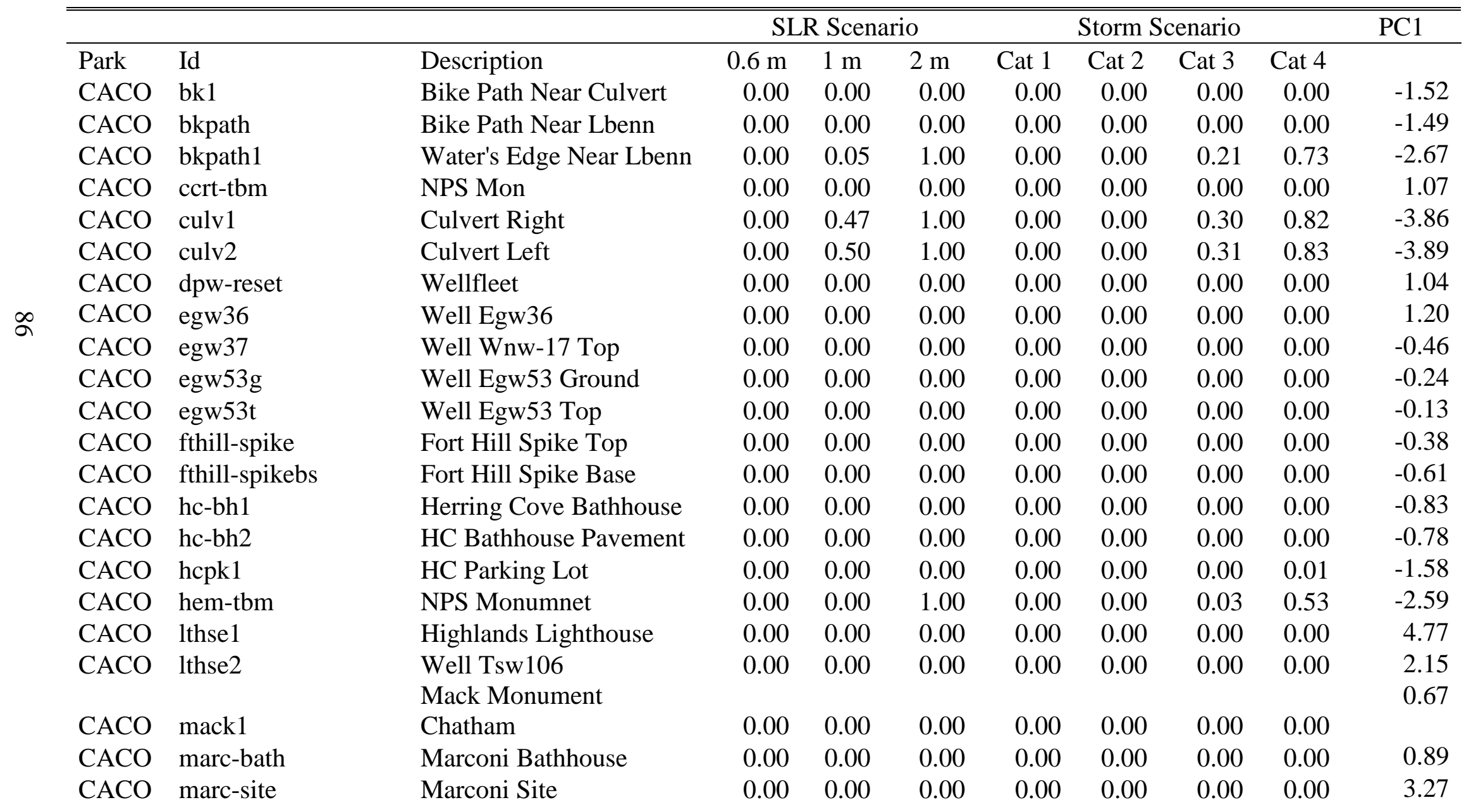




\begin{tabular}{|c|c|c|c|c|c|c|c|c|c|c|}
\hline CACO & naus-lh & Nauset Light & 0.00 & 0.00 & 0.00 & 0.00 & 0.00 & 0.00 & 0.00 & 1.42 \\
\hline $\mathrm{CACO}$ & naus-lot & Nauset Beach Lot & 0.00 & 0.00 & 0.00 & 0.00 & 0.00 & 0.00 & 0.00 & -0.72 \\
\hline $\mathrm{CACO}$ & penniman & Penniman House & 0.00 & 0.00 & 0.00 & 0.00 & 0.00 & 0.00 & 0.00 & 0.65 \\
\hline $\mathrm{CACO}$ & penniman1 & Penniman House 2 & 0.00 & 0.00 & 0.00 & 0.00 & 0.00 & 0.00 & 0.00 & 0.69 \\
\hline CACO & pil-land1 & Pilgrim's Landing Mem & 0.00 & 0.00 & 0.00 & 0.00 & 0.00 & 0.00 & 0.01 & -1.59 \\
\hline CACO & pvc-amp1 & PVC Ampitheatre & 0.00 & 0.00 & 0.00 & 0.00 & 0.00 & 0.00 & 0.00 & 1.62 \\
\hline $\mathrm{CACO}$ & pvc-deck1 & PVC Deck & 0.00 & 0.00 & 0.00 & 0.00 & 0.00 & 0.00 & 0.00 & 3.24 \\
\hline $\mathrm{CACO}$ & $\mathrm{rm} 4$ & Provincetown RM & 0.00 & 0.00 & 0.00 & 0.00 & 0.00 & 0.00 & 0.00 & 3.07 \\
\hline $\mathrm{CACO}$ & rt6 & Route 6 Adj To Culvert & 0.00 & 0.00 & 0.00 & 0.00 & 0.00 & 0.00 & 0.00 & -0.88 \\
\hline CACO & spvc-amp & SPVC Ampitheatre & 0.00 & 0.00 & 0.00 & 0.00 & 0.00 & 0.00 & 0.00 & -0.37 \\
\hline CACO & spvc-boat & SPVC Boat & 0.00 & 0.00 & 0.00 & 0.00 & 0.00 & 0.00 & 0.00 & 0.60 \\
\hline CACO & spvc-well-egw60 & Well Egw60 & 0.00 & 0.00 & 0.00 & 0.00 & 0.00 & 0.00 & 0.00 & 0.55 \\
\hline CACO & stone-jetty1 & Stone Jetty Top & 0.00 & 0.00 & 0.00 & 0.00 & 0.00 & 0.00 & 0.05 & -2.40 \\
\hline $\mathrm{CACO}$ & stone-jetty2 & Stone Jetty Mid & 0.00 & 0.00 & 0.21 & 0.00 & 0.00 & 0.00 & 0.20 & -1.89 \\
\hline CACO & stone-jetty3 & Stone Jetty Mid2 & 0.00 & 0.00 & 0.85 & 0.00 & 0.00 & 0.02 & 0.36 & -3.15 \\
\hline $\mathrm{CACO}$ & wellpt5-gr & Well Pt5 Ground & 0.00 & 0.00 & 0.17 & 0.00 & 0.00 & 0.00 & 0.05 & -1.19 \\
\hline $\mathrm{CACO}$ & well-pt5 & Well Pt5 & 0.00 & 0.00 & 0.00 & 0.00 & 0.00 & 0.00 & 0.00 & -0.98 \\
\hline $\mathrm{CACO}$ & wgw17bot & Well Wgw17 Ground & 0.00 & 0.00 & 0.00 & 0.00 & 0.00 & 0.00 & 0.00 & -0.52 \\
\hline $\mathrm{CACO}$ & whale & Whale Arch At Penniman & 0.00 & 0.00 & 0.00 & 0.00 & 0.00 & 0.00 & 0.00 & 0.42 \\
\hline CACO & caco2011cg & Coast Guard House & 0.00 & 0.00 & 0.00 & 0.00 & 0.00 & 0.00 & 0.00 & 0.47 \\
\hline $\mathrm{CACO}$ & caco2011herr & Herring River Backbone & 0.00 & 0.00 & 0.00 & 0.00 & 0.00 & 0.00 & 0.00 & 0.55 \\
\hline $\mathrm{CACO}$ & CACO2011MARC & Marconi Headquarters & 0.00 & 0.00 & 0.00 & 0.00 & 0.00 & 0.00 & 0.00 & 1.10 \\
\hline CACO & CACO2011MHWY & $\begin{array}{l}\text { Truro-Ptown Median Rt } 6 \\
\text { North Atlantic Lab }\end{array}$ & 0.00 & 0.00 & 1.00 & 0.00 & 0.00 & 0.00 & 0.00 & -1.84 \\
\hline CACO & caco2011nacl & $\begin{array}{l}\text { Concrete } \\
\text { Visitor's Center Parking }\end{array}$ & 0.00 & 0.00 & 0.00 & 0.00 & 0.00 & 0.00 & 0.00 & $\begin{array}{l}5.56 \\
2.28\end{array}$ \\
\hline CACO & сасо2011pvc & Lot & 0.00 & 0.00 & 0.00 & 0.00 & 0.00 & 0.00 & 0.00 & \\
\hline CACO & Frazier & Ngs & 0.00 & 0.00 & 0.00 & 0.00 & 0.00 & 0.00 & 0.00 & 4.66 \\
\hline
\end{tabular}




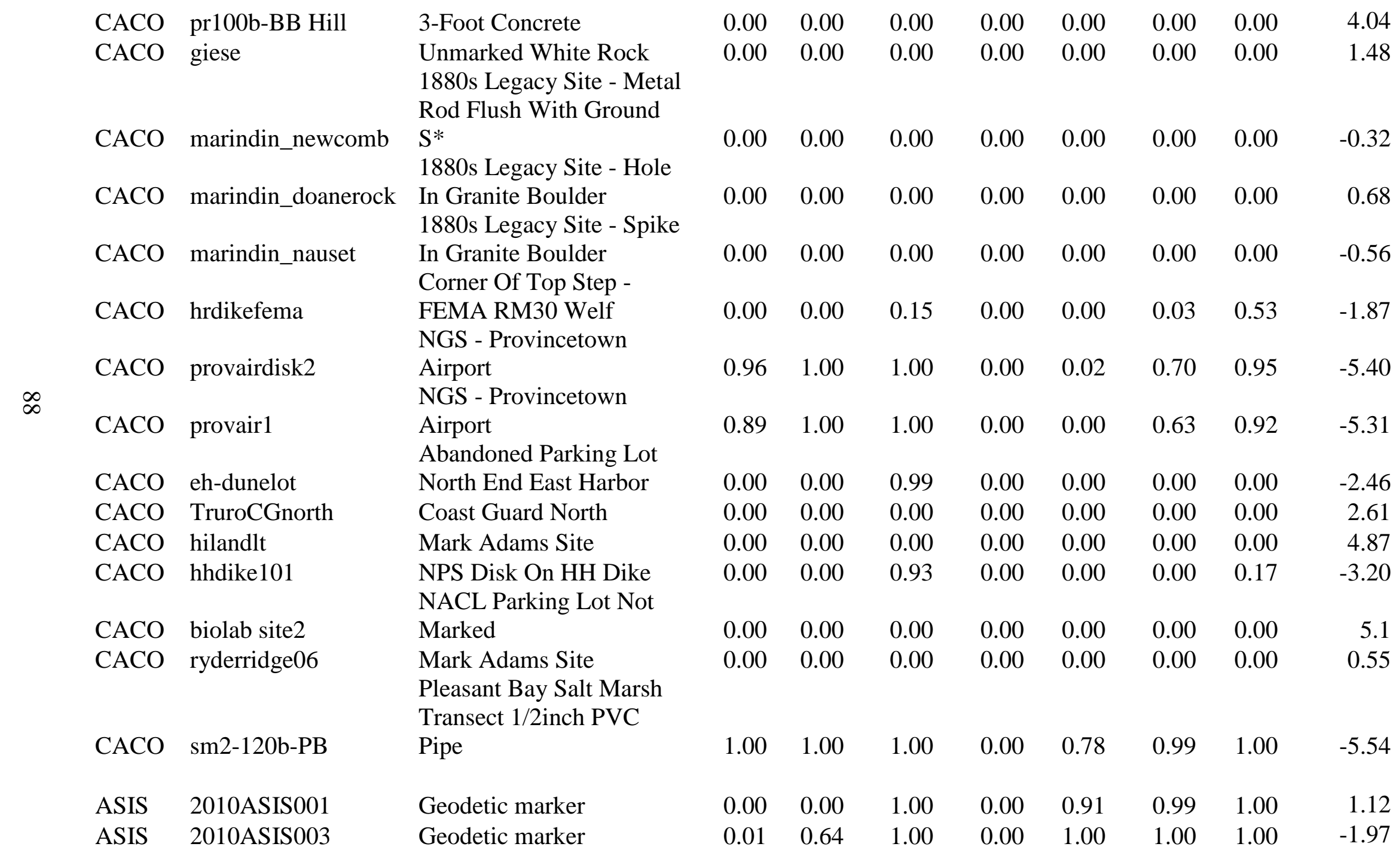




\begin{tabular}{|c|c|c|c|c|c|c|c|c|c|c|}
\hline ASIS & 2010ASIS004 & Geodetic marker & 0.06 & 0.89 & 1.00 & 0.00 & 1.00 & 1.00 & 1.00 & -2.79 \\
\hline ASIS & 2010ASIS005 & Geodetic marker & 0.00 & 0.39 & 1.00 & 0.00 & 0.95 & 0.99 & 1.00 & 0.66 \\
\hline ASIS & 2010ASIS006 & Geodetic marker & 0.00 & 0.00 & 0.22 & 0.00 & 0.08 & 0.77 & 0.98 & 6.01 \\
\hline ASIS & 2010ASIS008 & Geodetic marker & 0.16 & 0.96 & 1.00 & 0.00 & 0.58 & 1.00 & 1.00 & -0.43 \\
\hline ASIS & 2010ASIS009 & Geodetic marker & 0.02 & 0.75 & 1.00 & 0.16 & 0.97 & 1.00 & 1.00 & -0.43 \\
\hline ASIS & 2010ASIS010R & Geodetic marker & 0.00 & 0.39 & 1.00 & 0.01 & 0.00 & 0.96 & 1.00 & 1.67 \\
\hline ASIS & 2010ASISBAYR & Geodetic marker & 0.00 & 0.01 & 1.00 & 0.00 & 0.01 & 0.99 & 1.00 & 1.35 \\
\hline ASIS & 2010ASISCH1 & Geodetic marker & 0.01 & 0.59 & 1.00 & 0.04 & 0.03 & 0.99 & 1.00 & 0.45 \\
\hline ASIS & 2010ASISCH2 & Geodetic marker & 0.00 & 0.56 & 1.00 & 0.01 & 0.07 & 0.99 & 1.00 & 0.42 \\
\hline ASIS & 2010ASISCH3R & Geodetic marker & 0.16 & 0.96 & 1.00 & 0.38 & 0.99 & 1.00 & 1.00 & -1.74 \\
\hline ASIS & 2010ASISCH4 & Geodetic marker & 1.00 & 1.00 & 1.00 & 0.98 & 1.00 & 1.00 & 1.00 & -5.55 \\
\hline ASIS & 2011ASIS002 & Geodetic marker & 0.00 & 0.21 & 1.00 & 0.00 & 0.98 & 1.00 & 1.00 & -0.11 \\
\hline ASIS & FW0527_G466 & Geodetic marker & 0.00 & 0.00 & 0.08 & 0.00 & 0.00 & 0.81 & 1.00 & 5.56 \\
\hline ASIS & GPS1 & Geodetic marker & 0.00 & 0.50 & 1.00 & 0.15 & 0.98 & 1.00 & 1.00 & -0.72 \\
\hline ASIS & GPS2 & Geodetic marker & 0.00 & 0.00 & 1.00 & 0.00 & 0.92 & 0.99 & 1.00 & 1.35 \\
\hline ASIS & GPS3 & Geodetic marker & 0.00 & 0.02 & 1.00 & 0.00 & 0.99 & 1.00 & 1.00 & 0.03 \\
\hline ASIS & GPS4 & Geodetic marker & 0.00 & 0.39 & 1.00 & 0.00 & 1.00 & 1.00 & 1.00 & -1.50 \\
\hline ASIS & gps6 & Geodetic marker & 0.06 & 0.90 & 1.00 & 0.00 & 0.11 & 0.99 & 1.00 & 0.17 \\
\hline ASIS & gps9 & Geodetic marker & 0.00 & 0.40 & 1.00 & 0.61 & 0.99 & 1.00 & 1.00 & -1.44 \\
\hline ASIS & gps10 & Geodetic marker & 0.04 & 0.84 & 1.00 & 0.25 & 0.98 & 1.00 & 1.00 & -0.86 \\
\hline ASIS & gps11 & Geodetic marker & 0.95 & 1.00 & 1.00 & 0.91 & 1.00 & 1.00 & 1.00 & -3.62 \\
\hline ASIS & gps12 & Geodetic marker & 0.01 & 0.67 & 1.00 & 0.00 & 0.44 & 1.00 & 1.00 & 0.45 \\
\hline ASIS & gps13 & Geodetic marker & 1.00 & 1.00 & 1.00 & 0.43 & 0.99 & 1.00 & 1.00 & -3.58 \\
\hline ASIS & gps14 & Geodetic marker & 0.07 & 0.91 & 1.00 & 0.31 & 0.98 & 1.00 & 1.00 & -1.16 \\
\hline ASIS & gps15 & Geodetic marker & 0.00 & 0.22 & 1.00 & 0.02 & 0.90 & 0.99 & 1.00 & 0.96 \\
\hline ASIS & gps16 & Geodetic marker & 0.17 & 0.97 & 1.00 & 0.41 & 0.95 & 1.00 & 1.00 & -1.06 \\
\hline ASIS & GPS17 & Geodetic marker & 0.70 & 1.00 & 1.00 & 0.67 & 0.82 & 1.00 & 1.00 & -1.82 \\
\hline ASIS & HU1023_B141 & Geodetic marker & 0.00 & 0.23 & 1.00 & 0.02 & 0.34 & 0.96 & 1.00 & 1.66 \\
\hline
\end{tabular}




\begin{tabular}{|c|c|c|c|c|c|c|c|c|c|c|}
\hline ASIS & HU1024_C141 & Geodetic marker & 0.00 & 0.09 & 1.00 & 0.01 & 0.39 & 0.94 & 1.00 & 1.99 \\
\hline ASIS & HU1026_M141 & Geodetic marker & 0.00 & 0.00 & 1.00 & 0.00 & 0.73 & 0.97 & 1.00 & 2.37 \\
\hline ASIS & HU1027_E141 & Geodetic marker & 0.00 & 0.00 & 1.00 & 0.00 & 0.77 & 0.98 & 1.00 & 2.08 \\
\hline ASIS & HU1583_NB2 & Geodetic marker & 0.00 & 0.00 & 1.00 & 0.13 & 0.95 & 0.99 & 1.00 & 0.47 \\
\hline
\end{tabular}




\section{APPENDIX 5}

Full park maps of model results 
Figure A5.1 CACO Bath-tub modeling of $1 \mathrm{~m}$ sea level rise. Shown are inundation probability classes as calculated with LiDAR elevations.

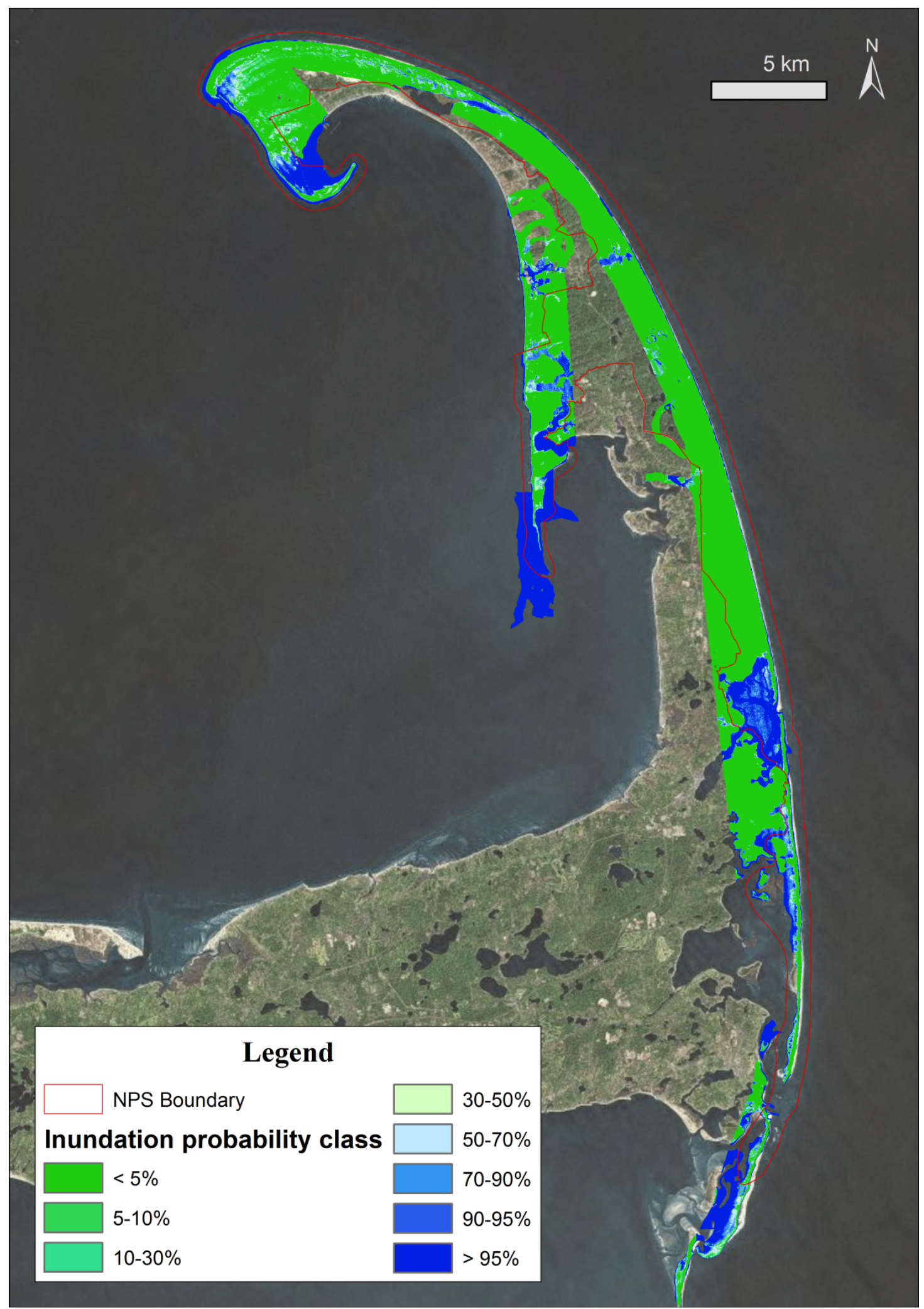


Figure A5.2 CACO Bath-tub modeling of $2 \mathrm{~m}$ sea level rise. Shown are inundation probability classes as calculated with LiDAR elevations.




Figure A5.3 ASIS Bath-tub modeling of $0.6 \mathrm{~m}$ sea level rise. Shown are inundation probability classes as calculated with LiDAR elevations.
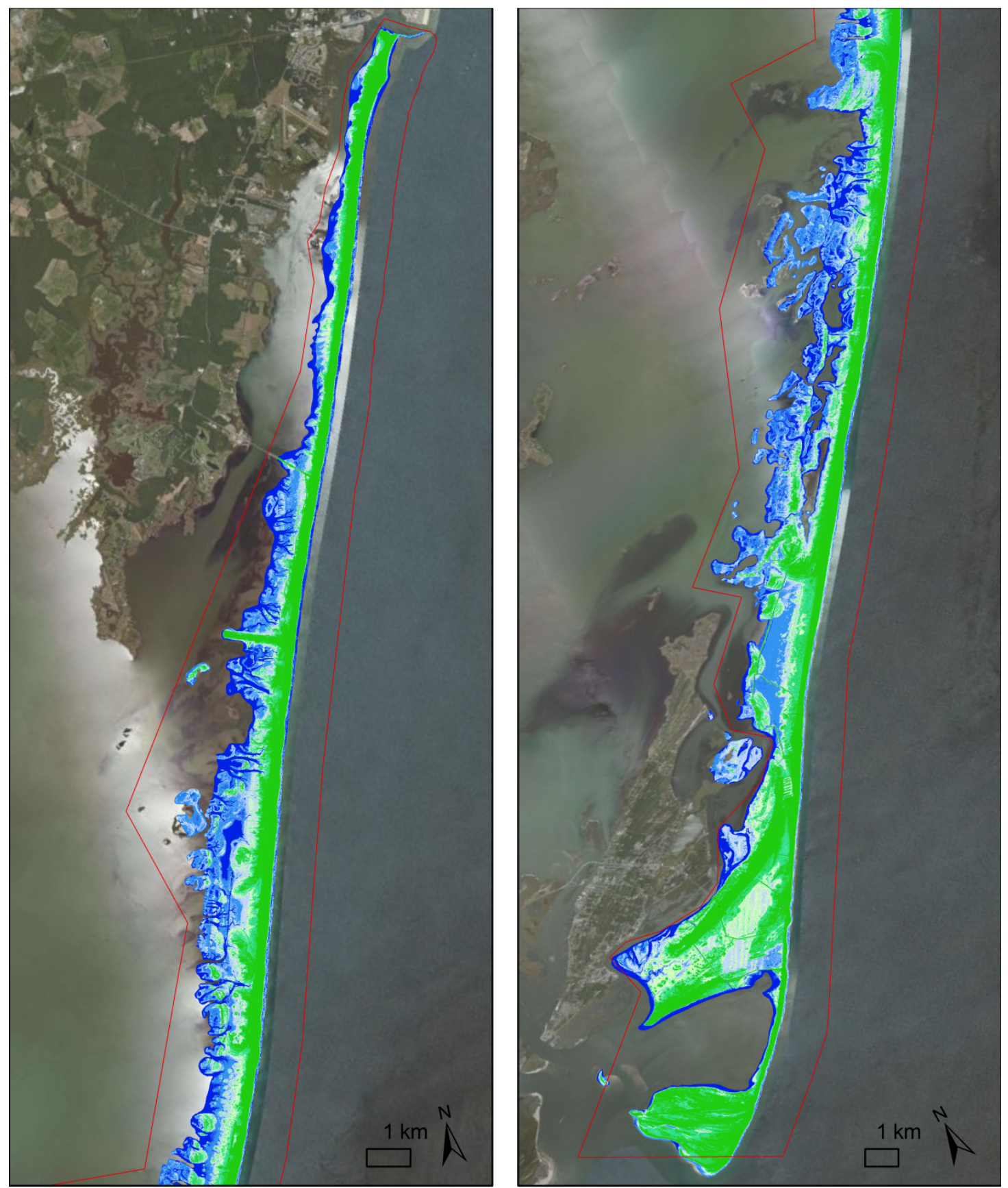

\section{Legend}

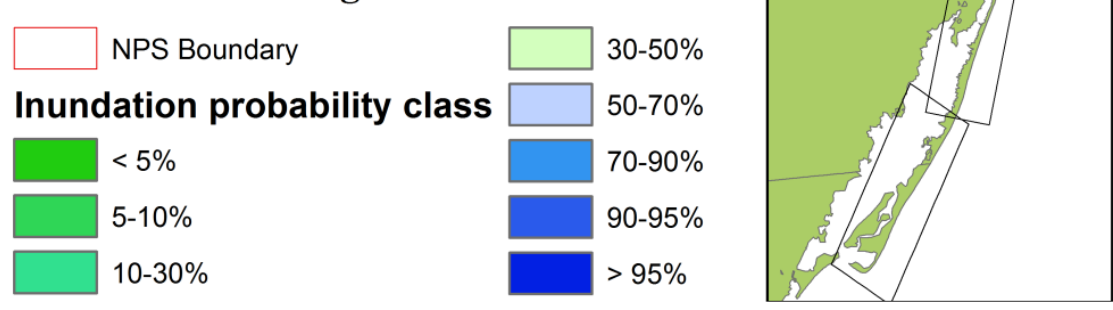


Figure A5.4 ASIS Bath-tub modeling of $1 \mathrm{~m}$ sea level rise. Shown are inundation probability classes as calculated with LiDAR elevation.
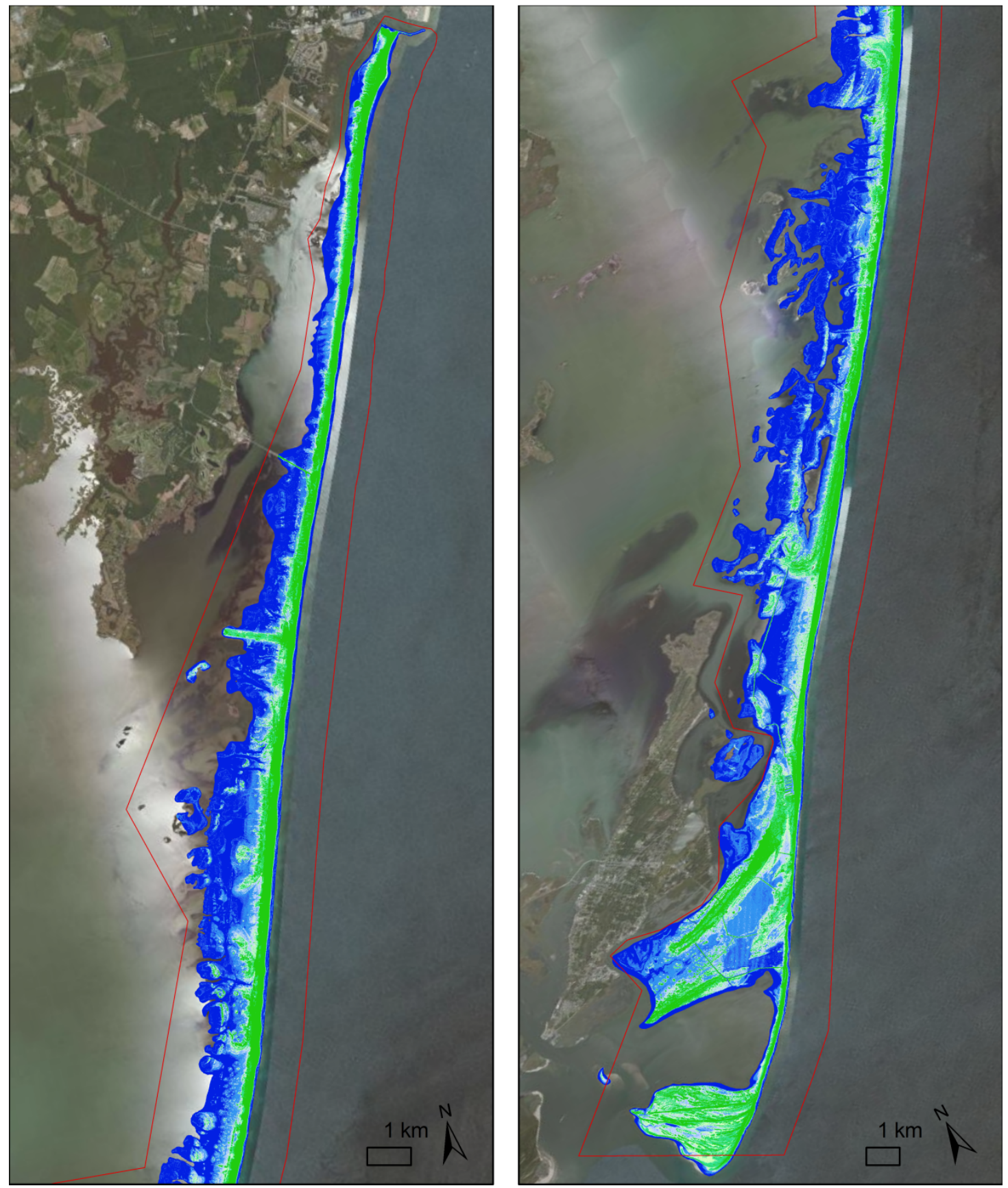

\section{Legend}

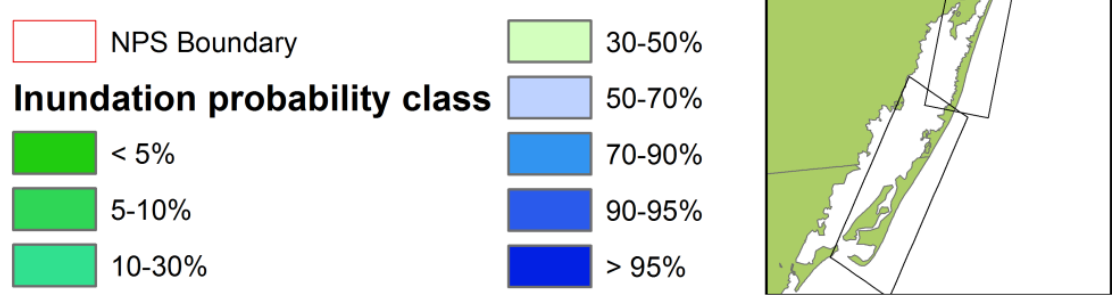


Figure A5.5 ASIS Bath-tub modeling of $2 \mathrm{~m}$ sea level rise. Shown are inundation probability classes as calculated with LiDAR elevations.

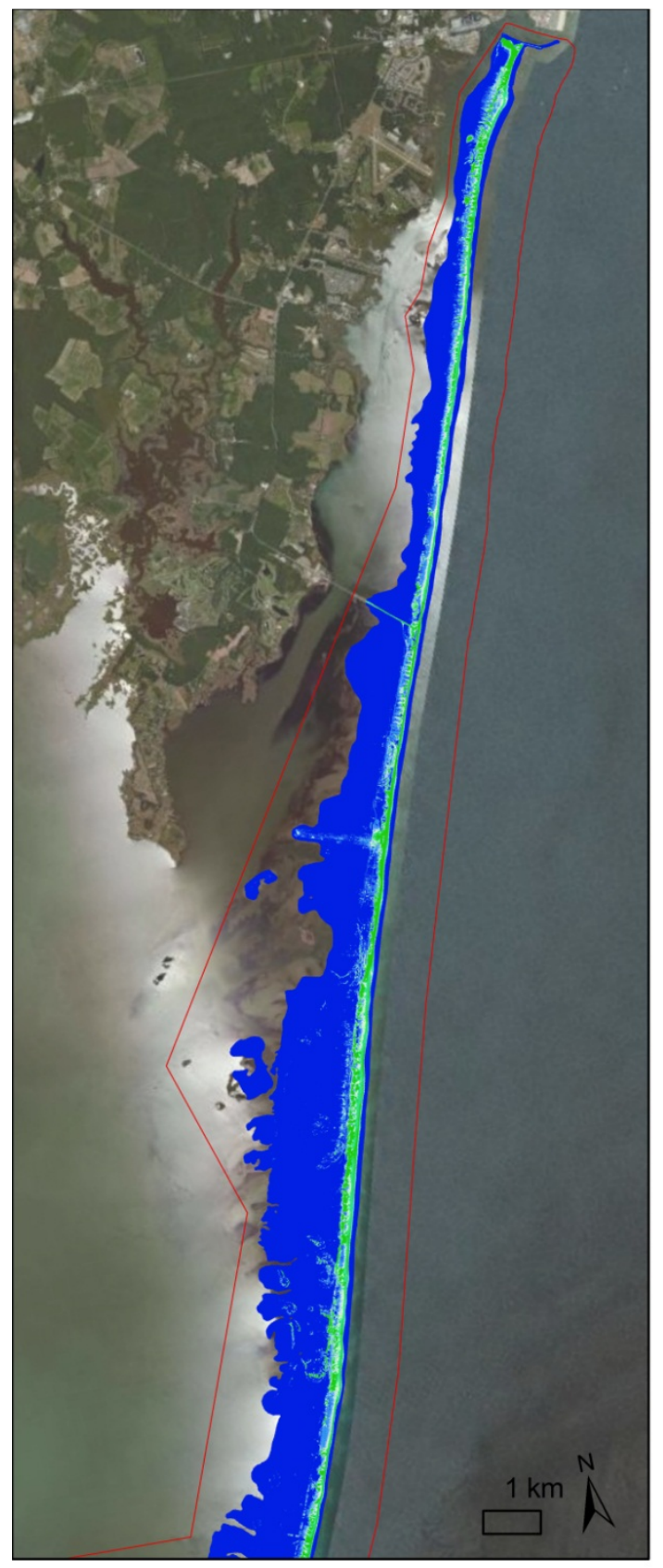

\section{Legend}

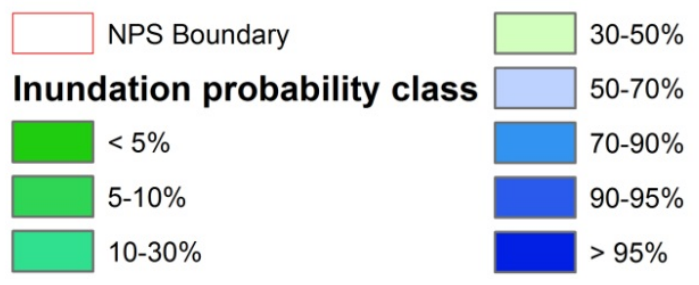

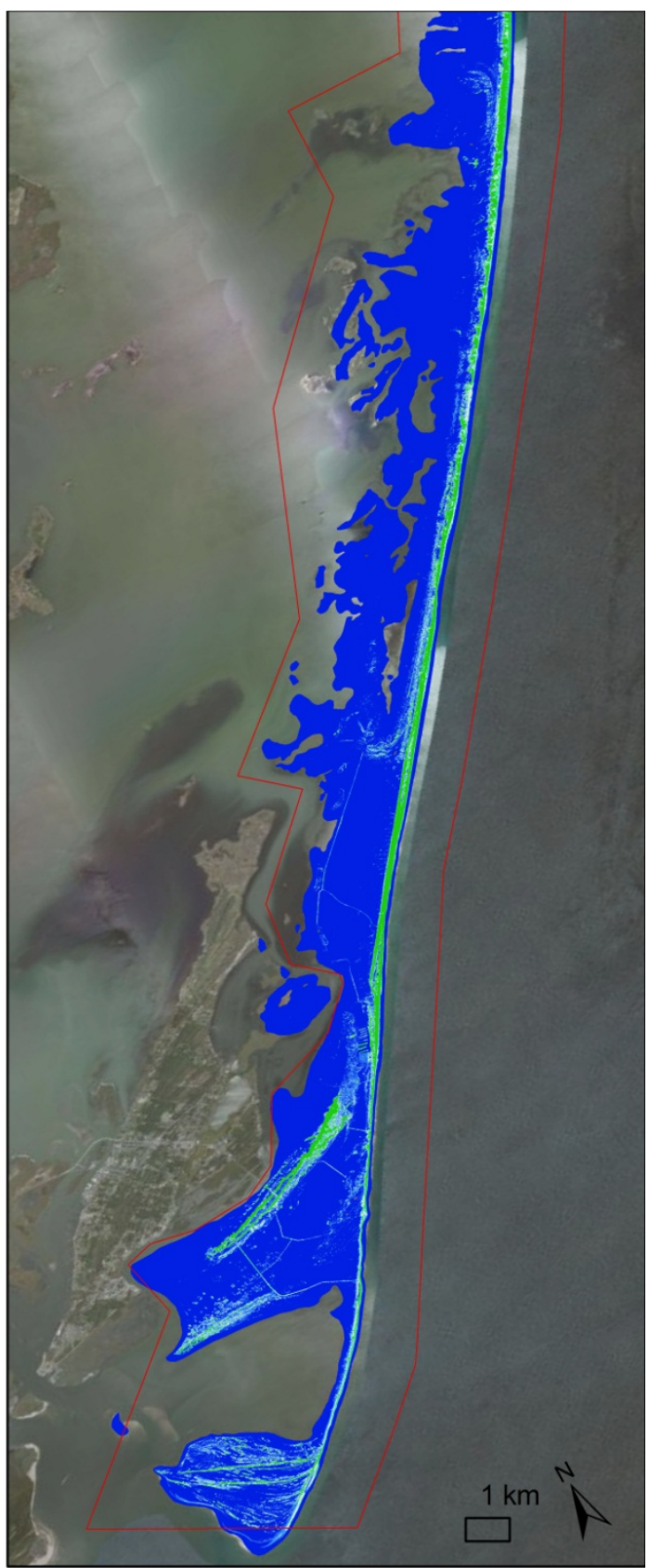

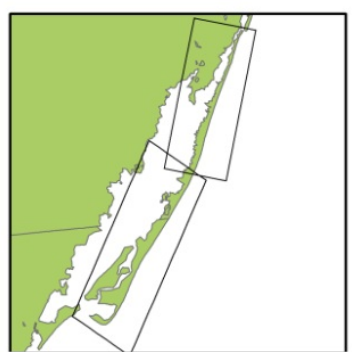


Figure A5.6 CACO Category I Hurricane inundation predicted by SLOSH.

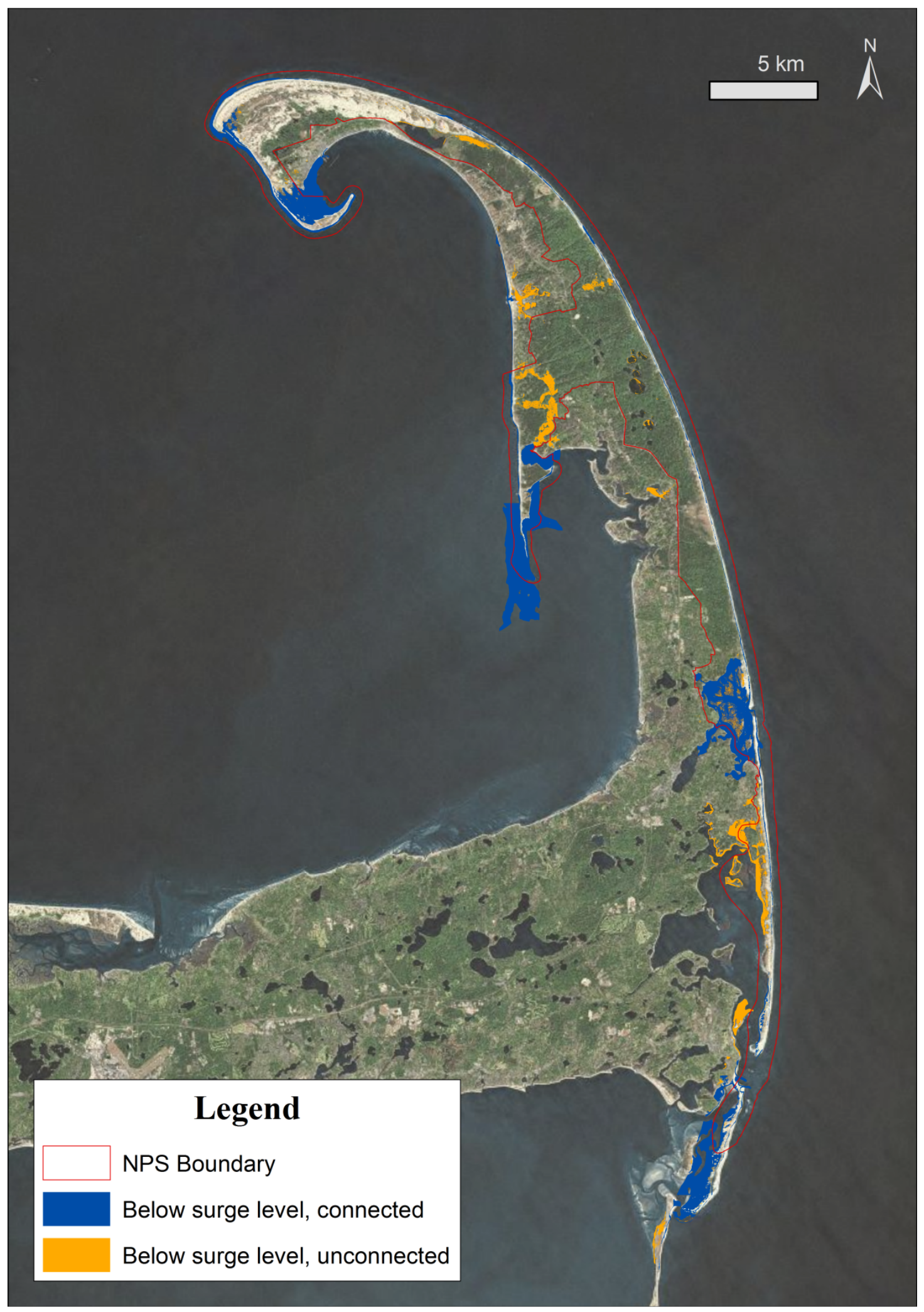


Figure A5.7 CACO Category 2 Hurricane inundation predicted by SLOSH.

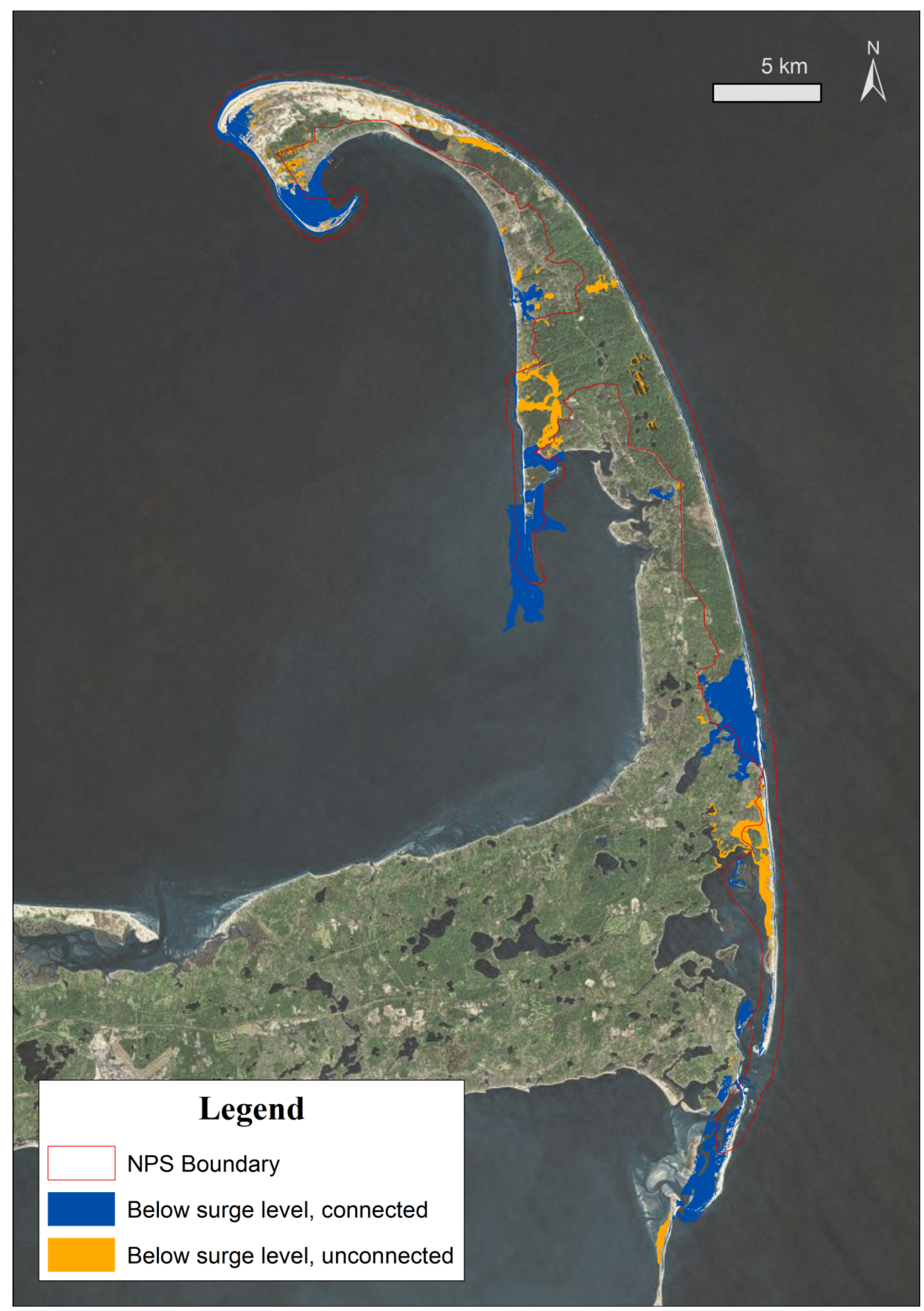


Figure A5.8 CACO Category 3 Hurricane inundation predicted by SLOSH.

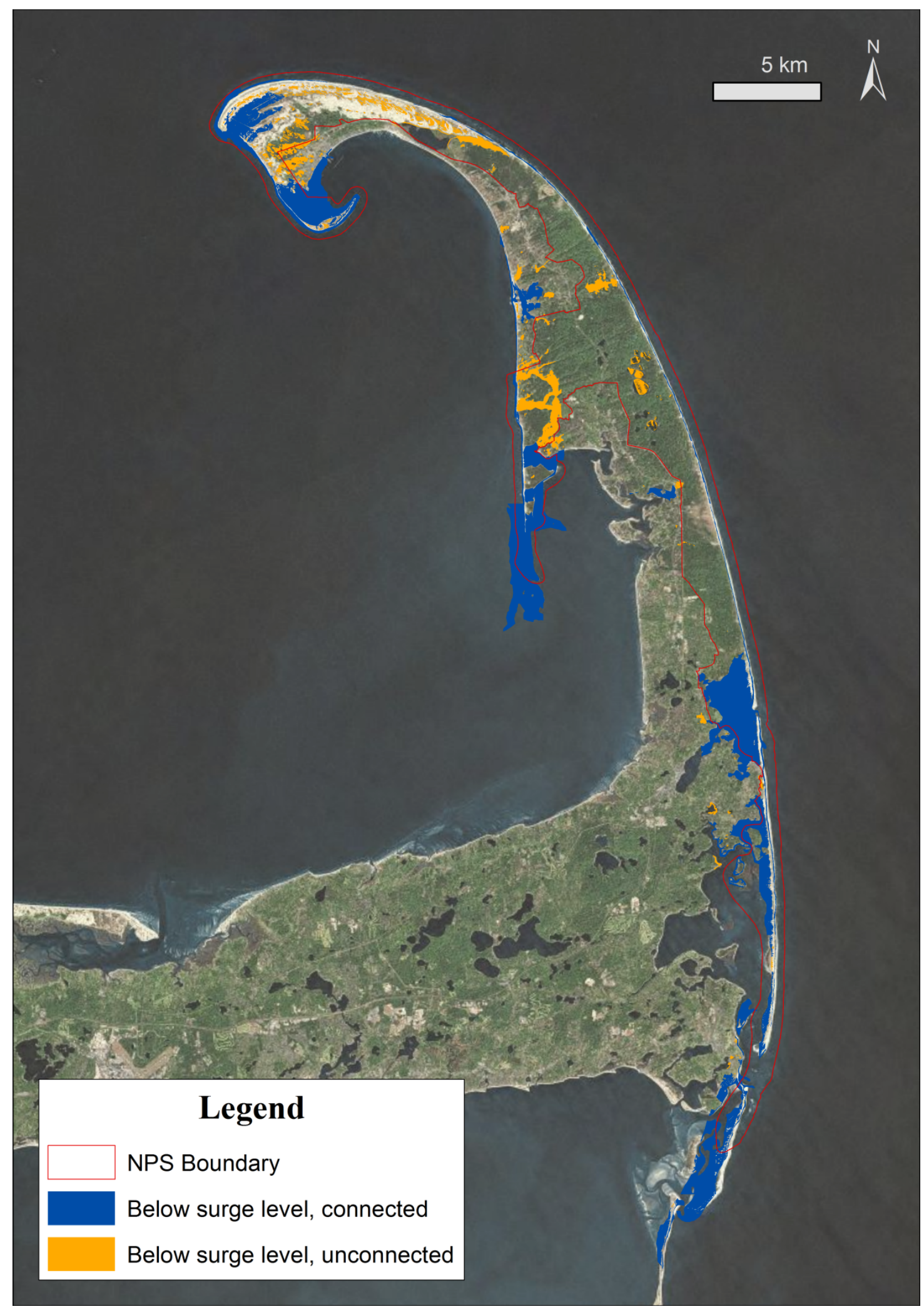


Figure A5.9 CACO Category 4 Hurricane inundation predicted by SLOSH.

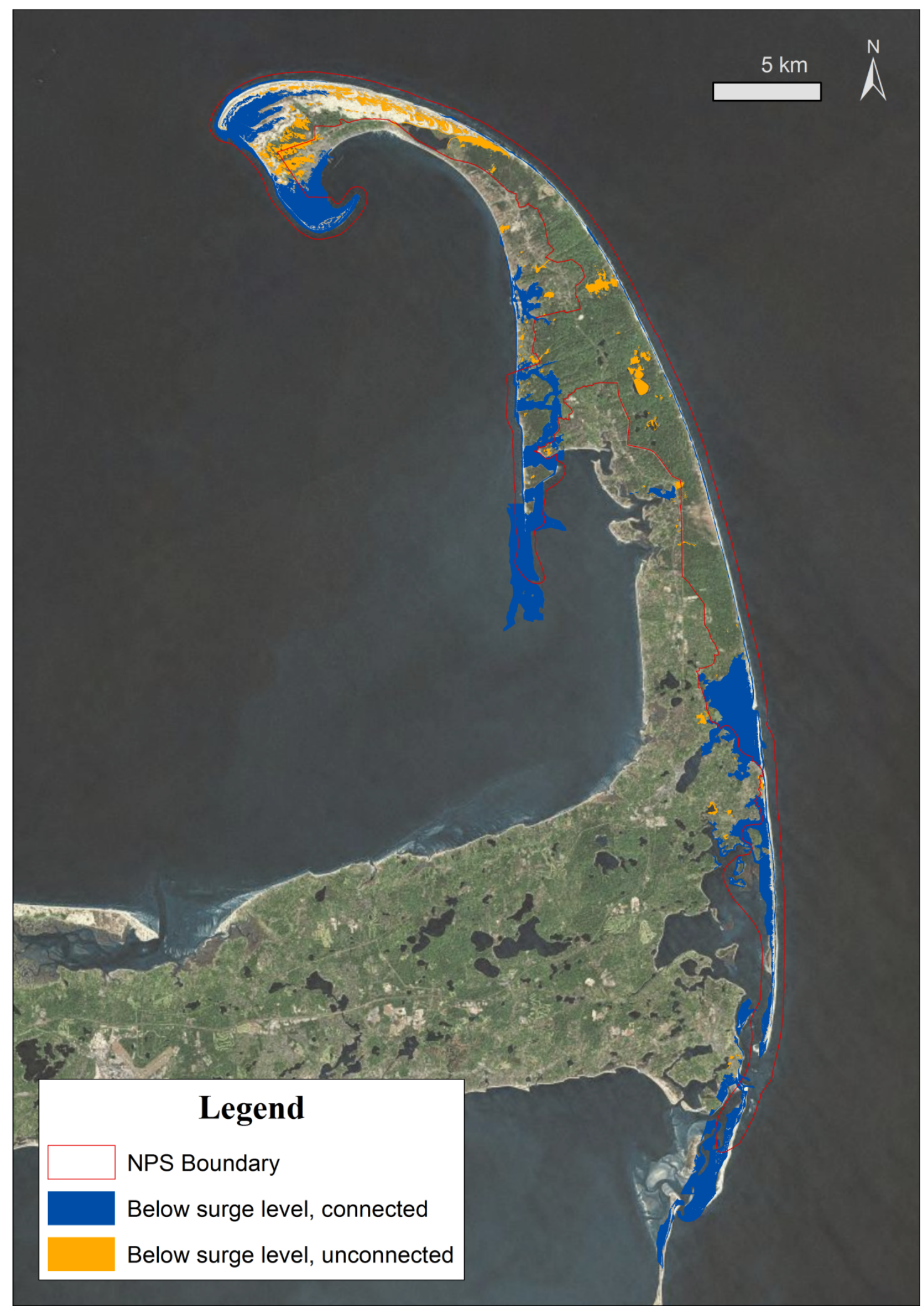


Figure A5.10 ASIS Category 1 Hurricane inundation predicted by SLOSH.
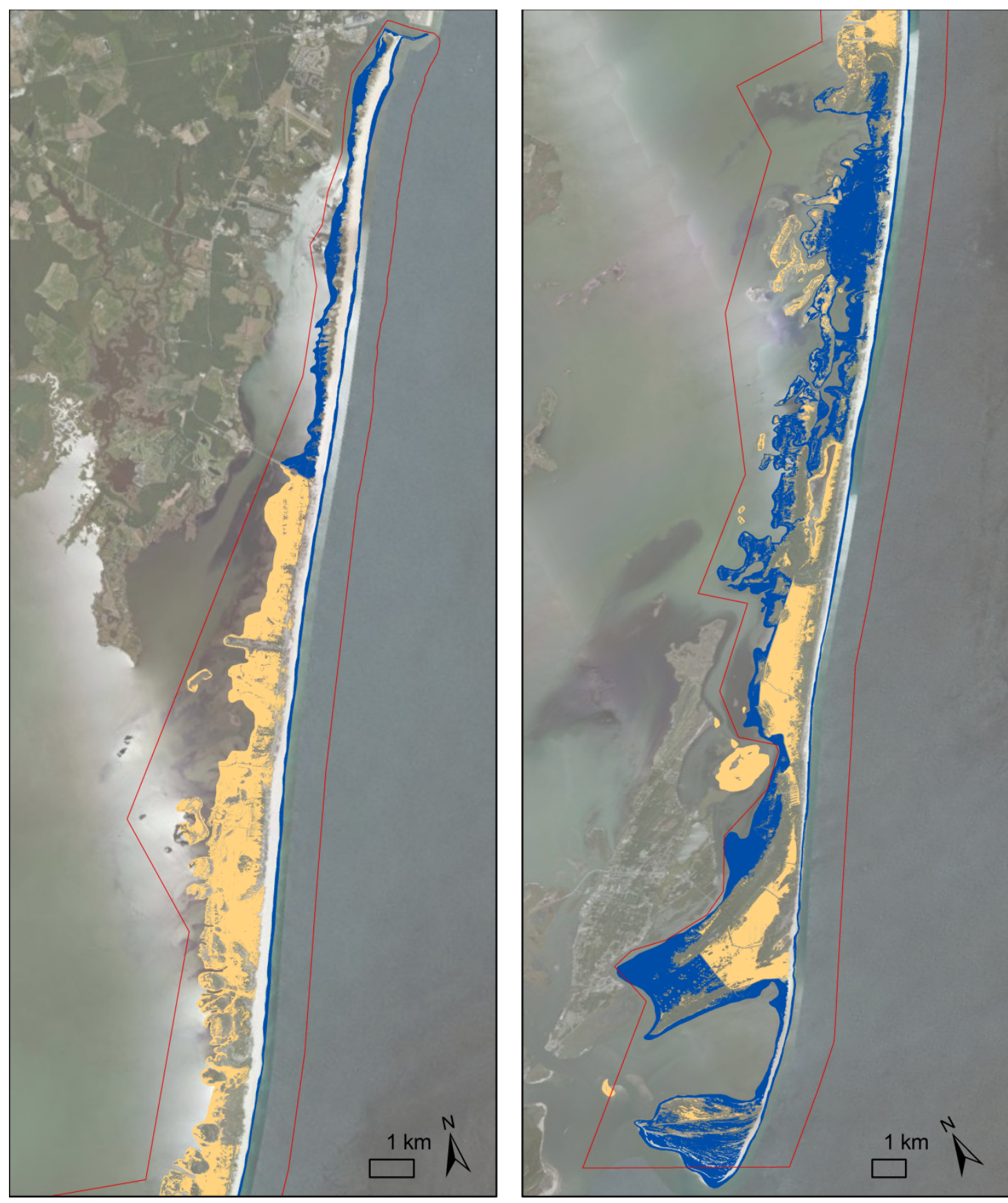

\section{Legend}

NPS Boundary

Below surge level, connected

Below surge level, unconnected

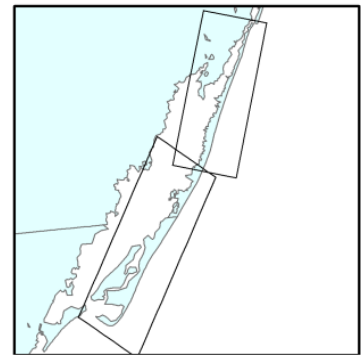


Figure A5.11 ASIS Category 2 Hurricane inundation predicted by SLOSH.
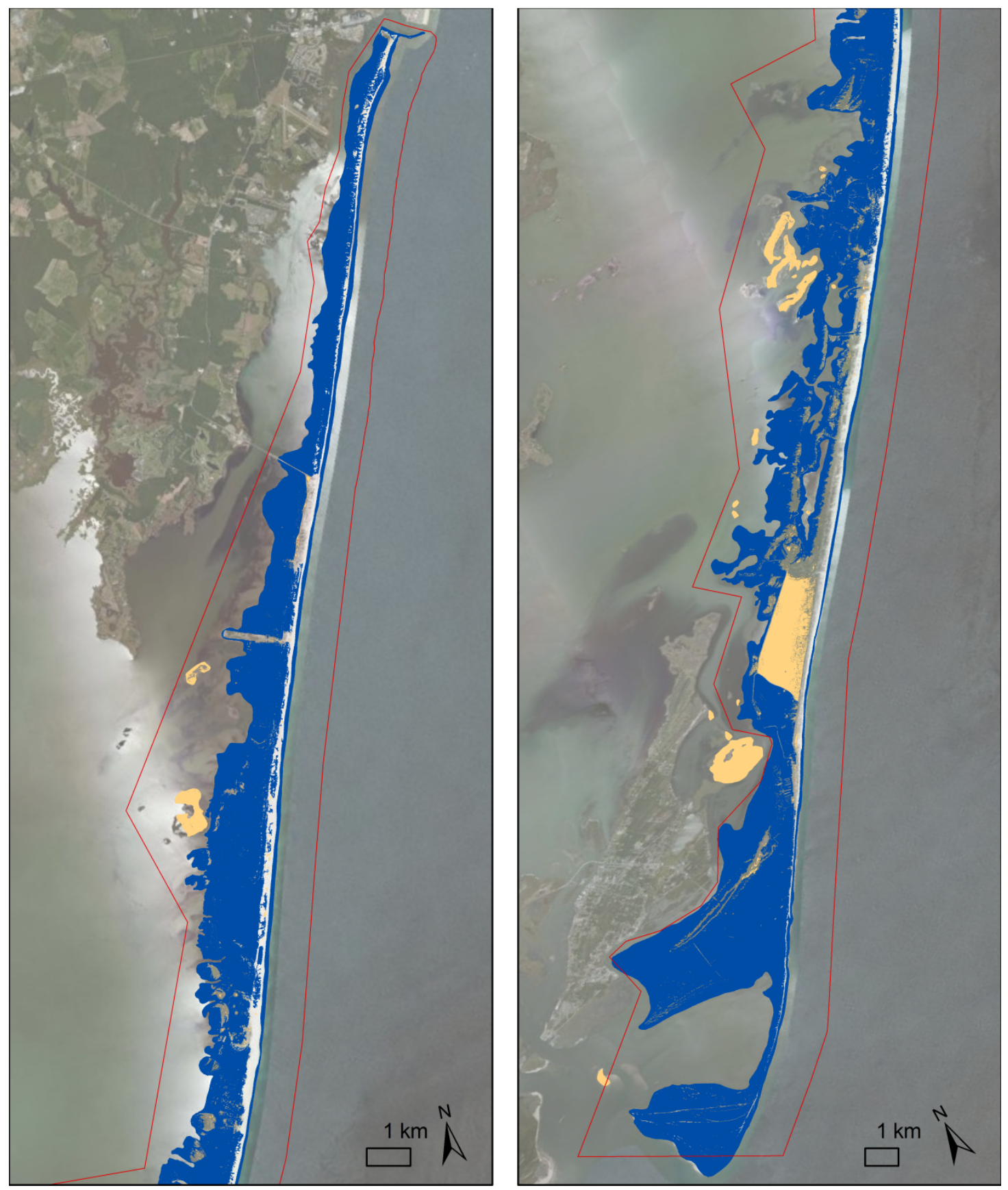

\section{Legend}

NPS Boundary

Below surge level, connected

Below surge level, unconnected

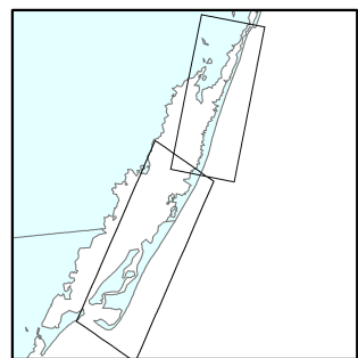


Figure A5.12 ASIS Category 3 Hurricane inundation predicted by SLOSH.
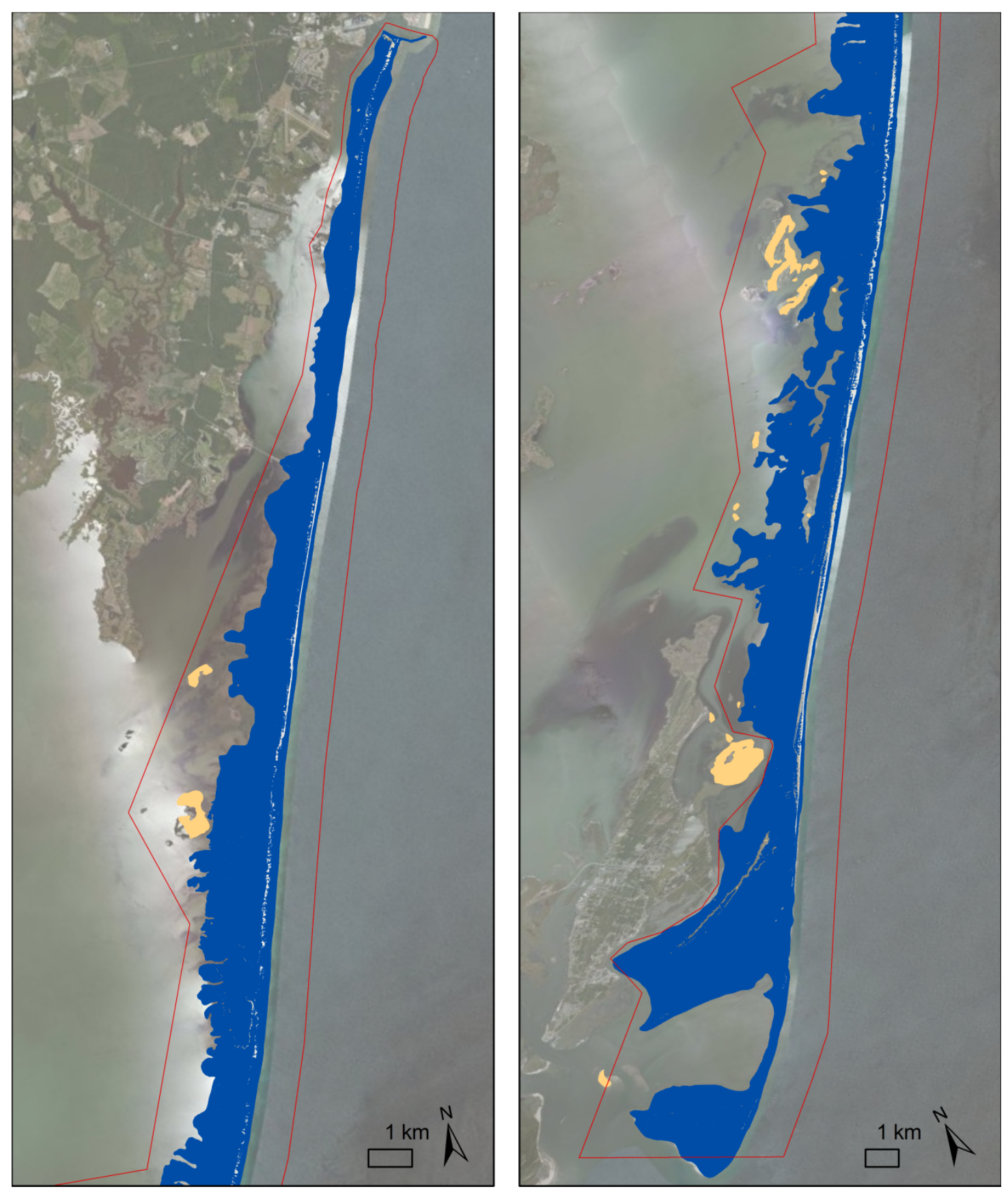

\section{Legend}

NPS Boundary

Below surge level, connected

Below surge level, unconnected

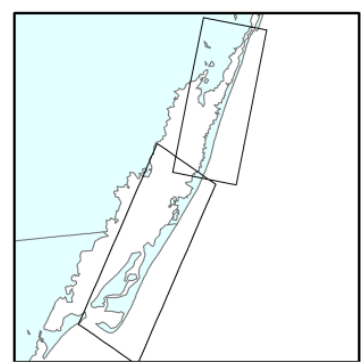


Figure A5.13 ASIS Category 4 Hurricane inundation predicted by SLOSH.
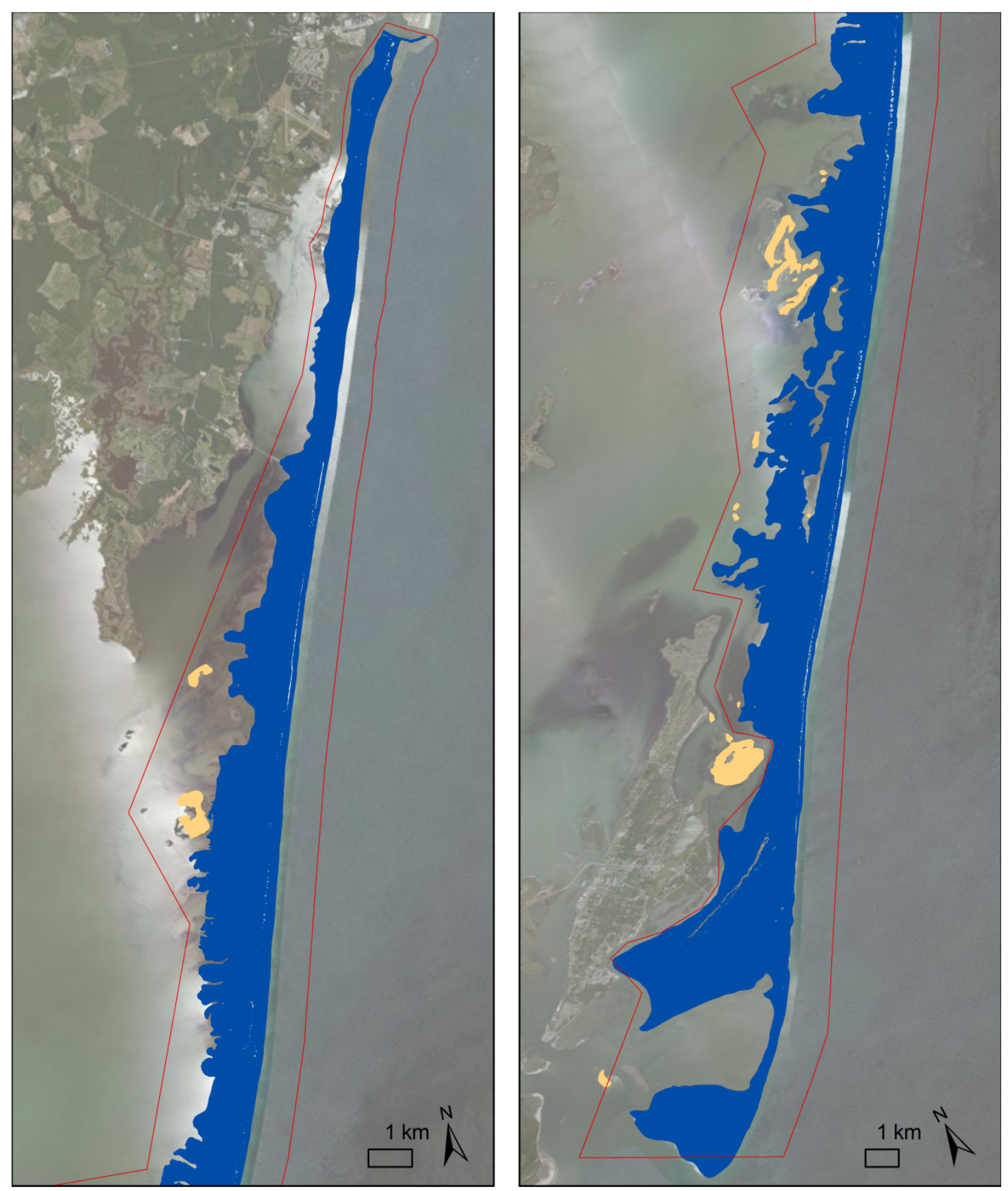

\section{Legend}

NPS Boundary

Below surge level, connected

Below surge level, unconnected

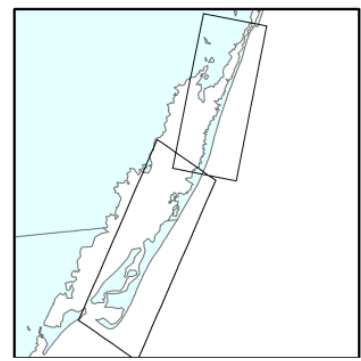


Figure A5.14 CACO SLAMM Input: Initial conditions.

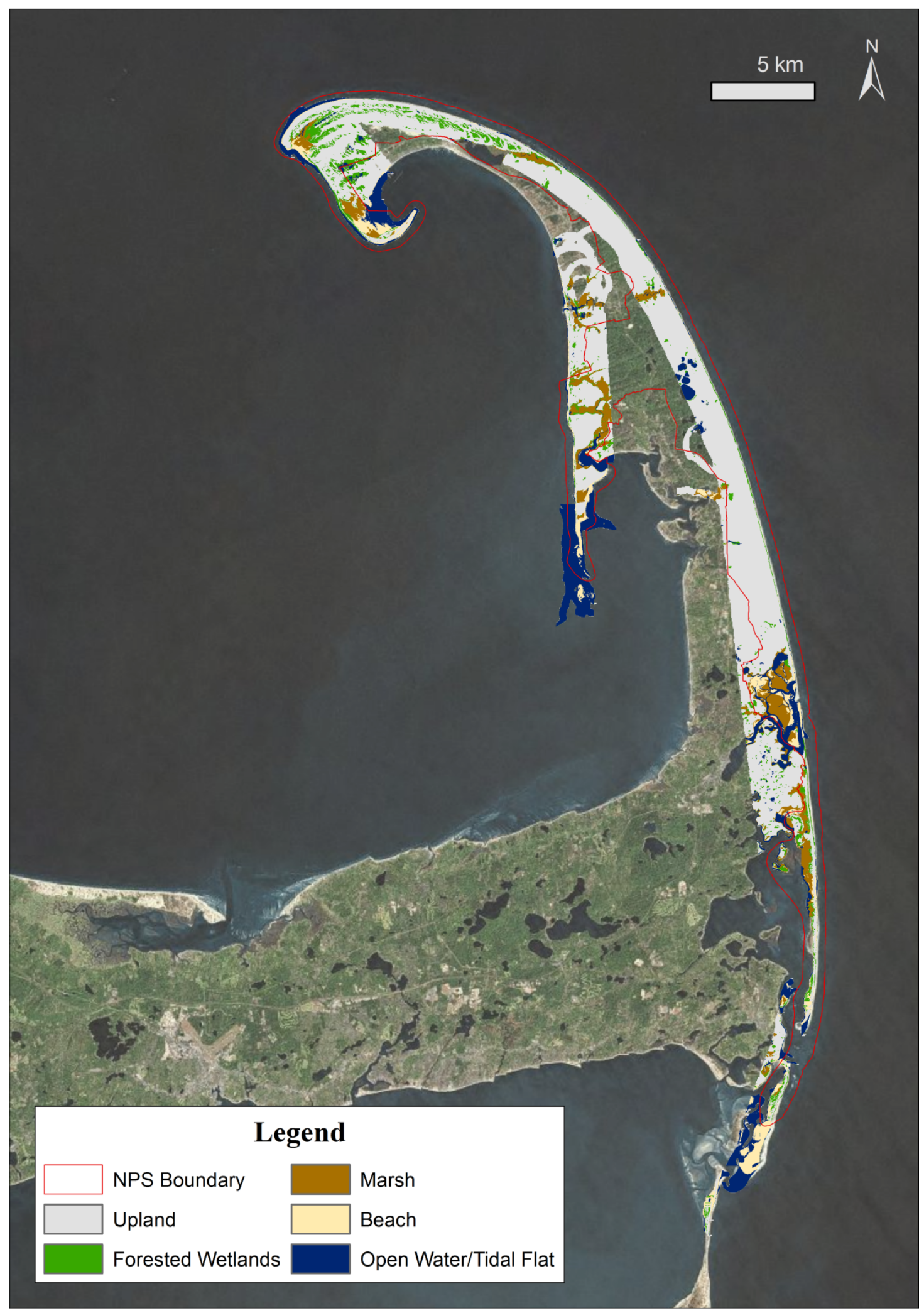


Figure A5.15 CACO SLAMM Output: $1 \mathrm{~m}$ sea level rise scenario.

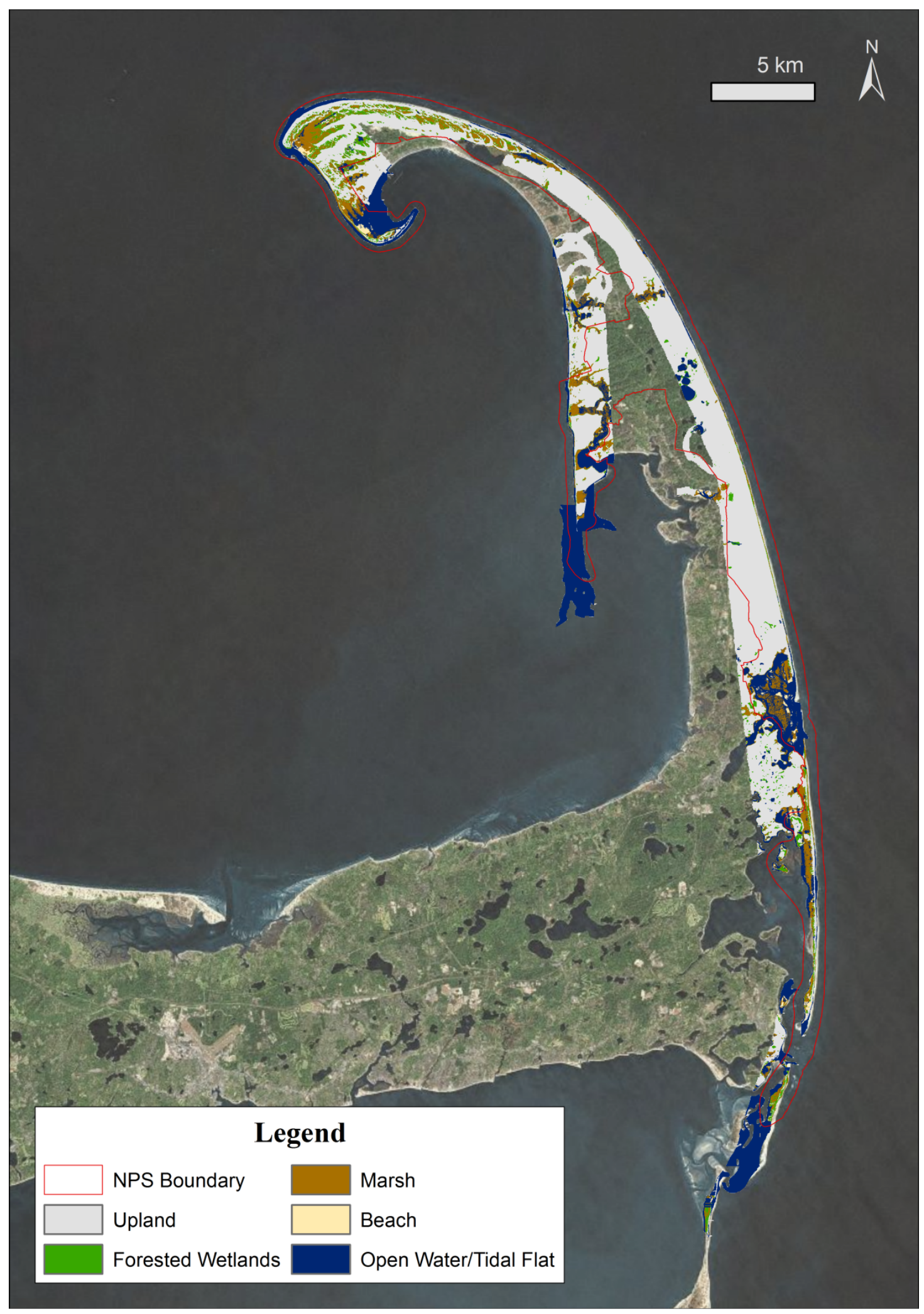


Figure A5.16 CACO SLAMM Output: $2 \mathrm{~m}$ sea level rise scenario.

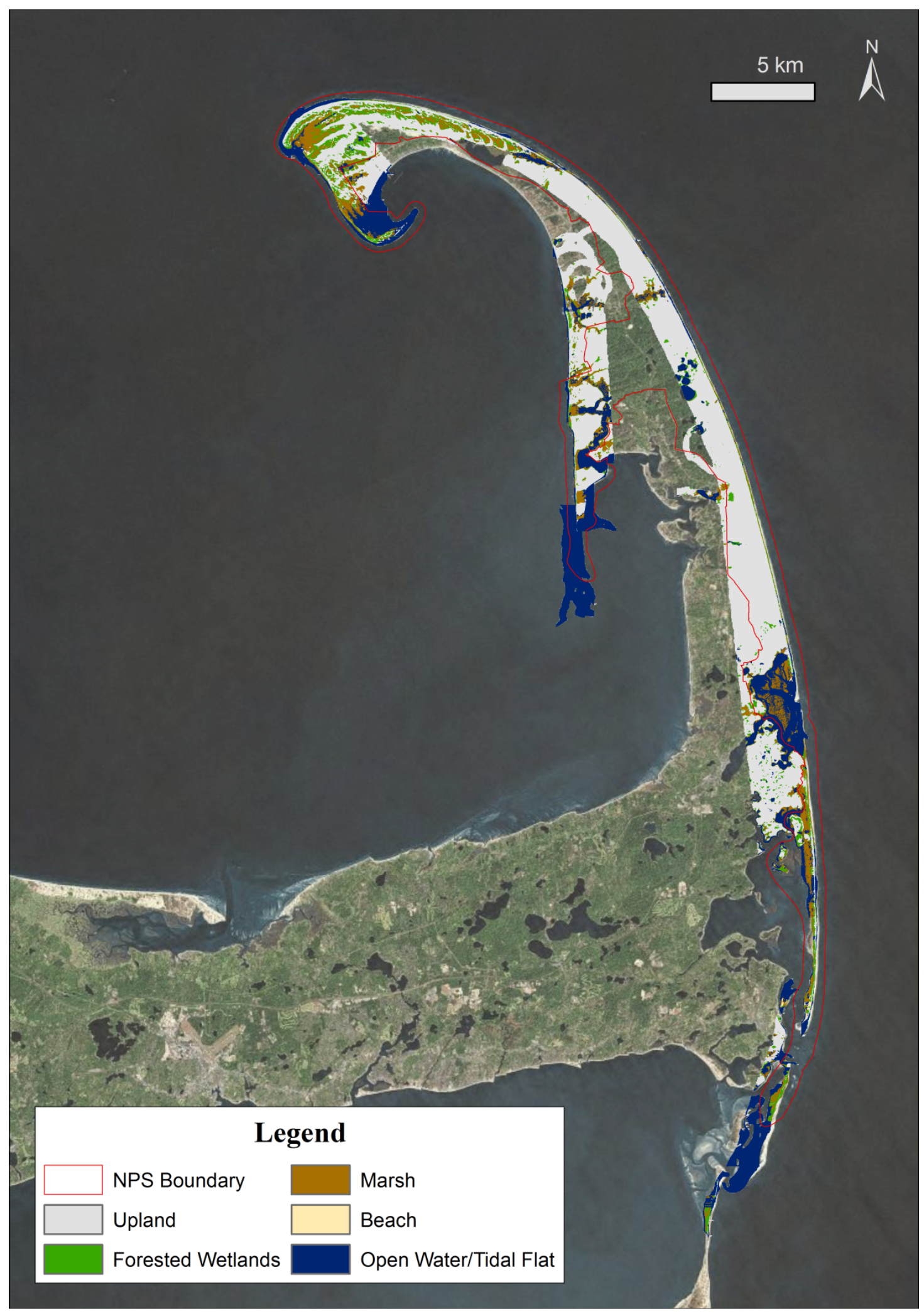


Figure A5.17 ASIS SLAMM Input: Initial conditions.
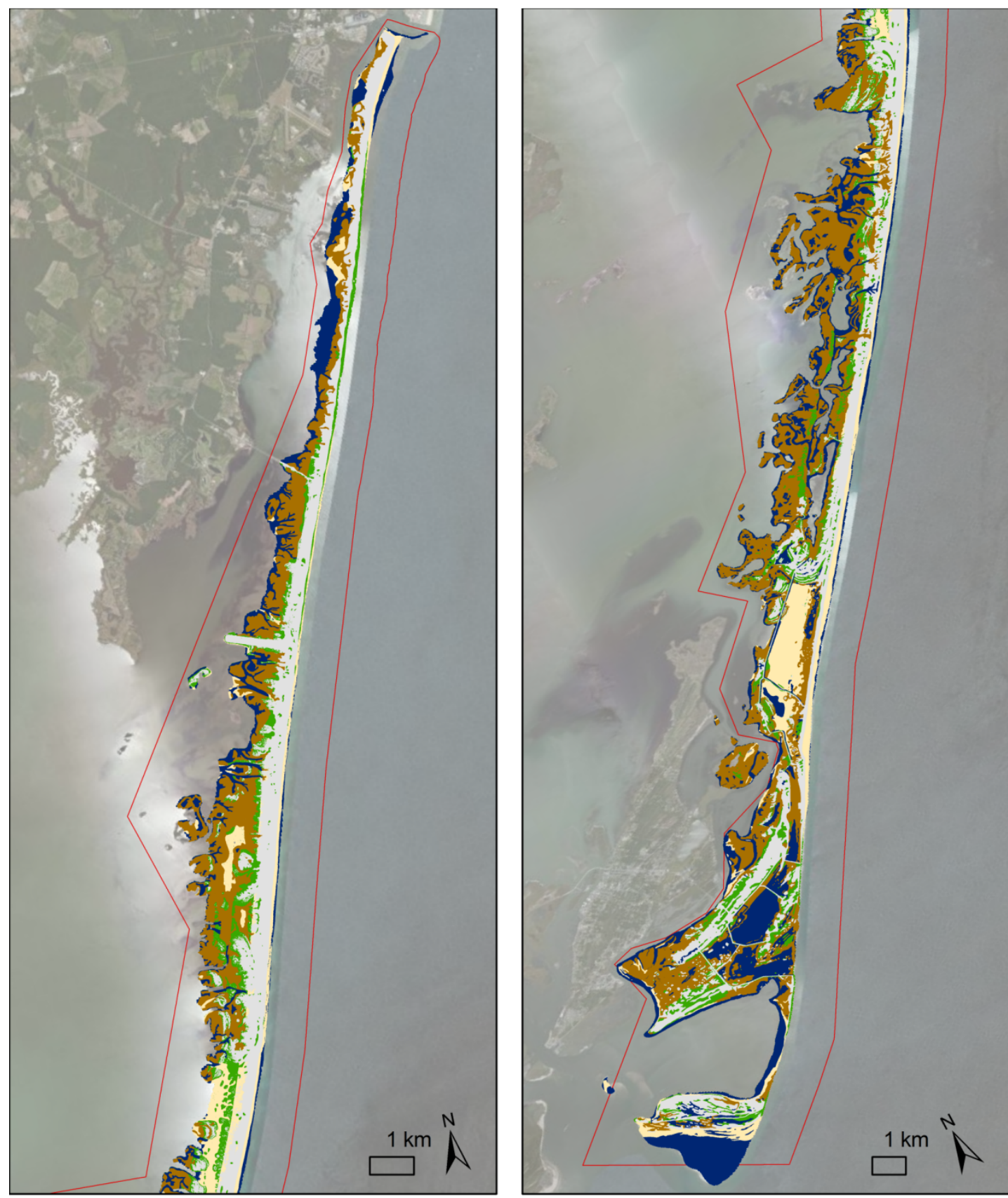

\section{Legend}

\begin{tabular}{|l|l|}
$\square$ & MPS Boundary \\
$\square$ & Upland \\
Forested Wetlands & Beach \\
& Open Water/Tidal Flat
\end{tabular}

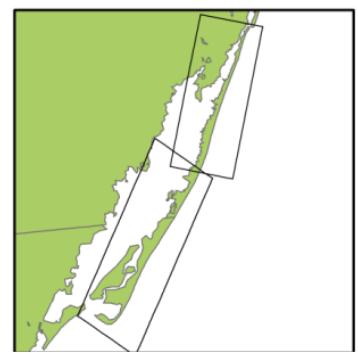


Figure A5.18 ASIS SLAMM Output: $0.6 \mathrm{~m}$ sea level rise scenario.
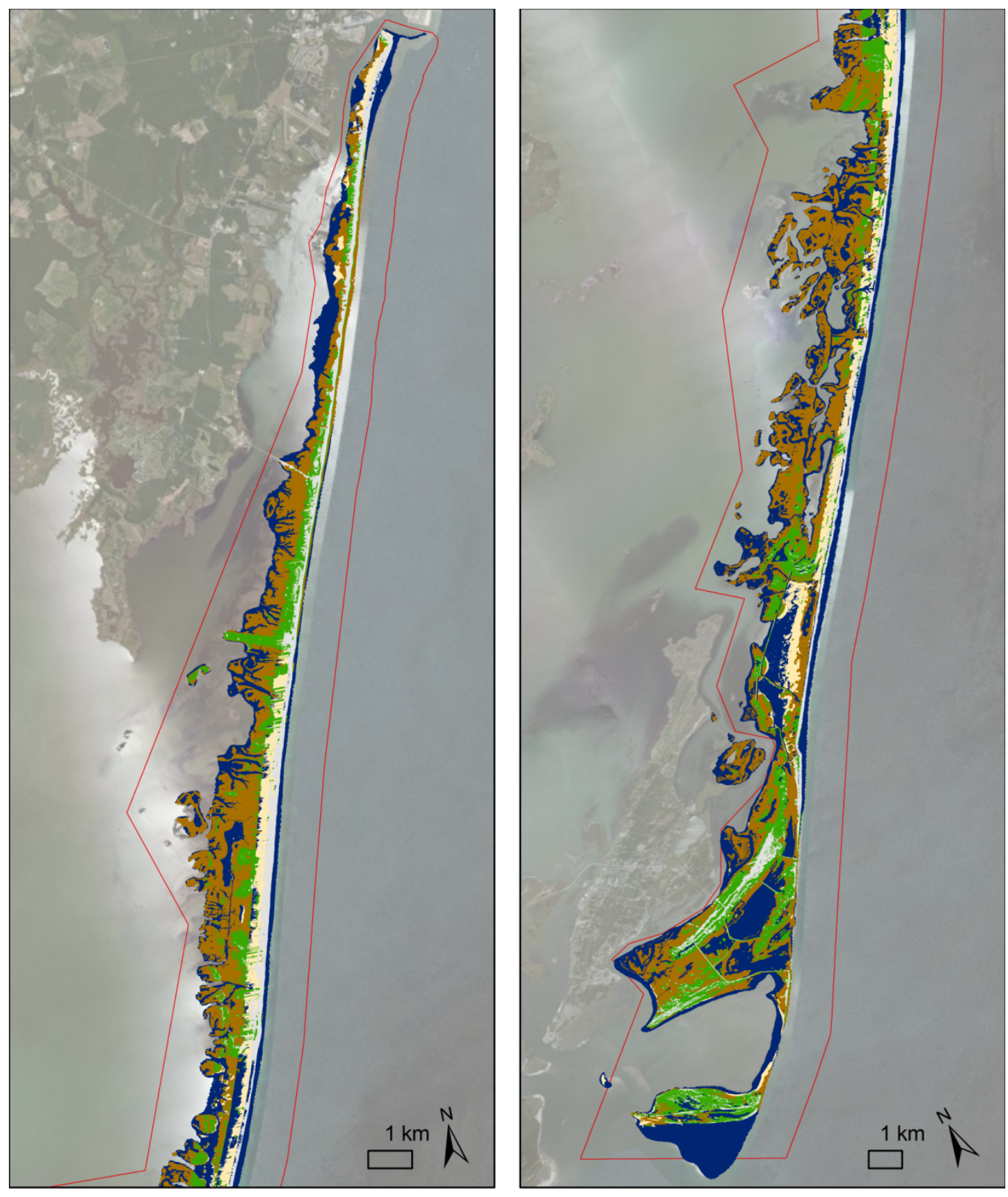

\section{Legend}

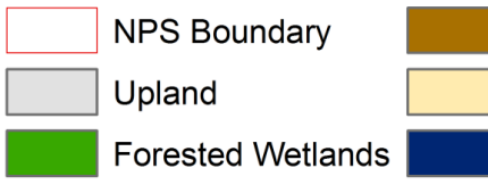

Marsh

Beach

Open Water/Tidal Flat

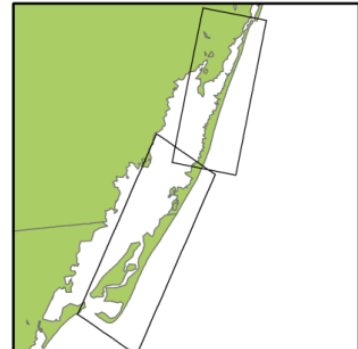


Figure A5.19 ASIS SLAMM Output: $1 \mathrm{~m}$ sea level rise scenario.
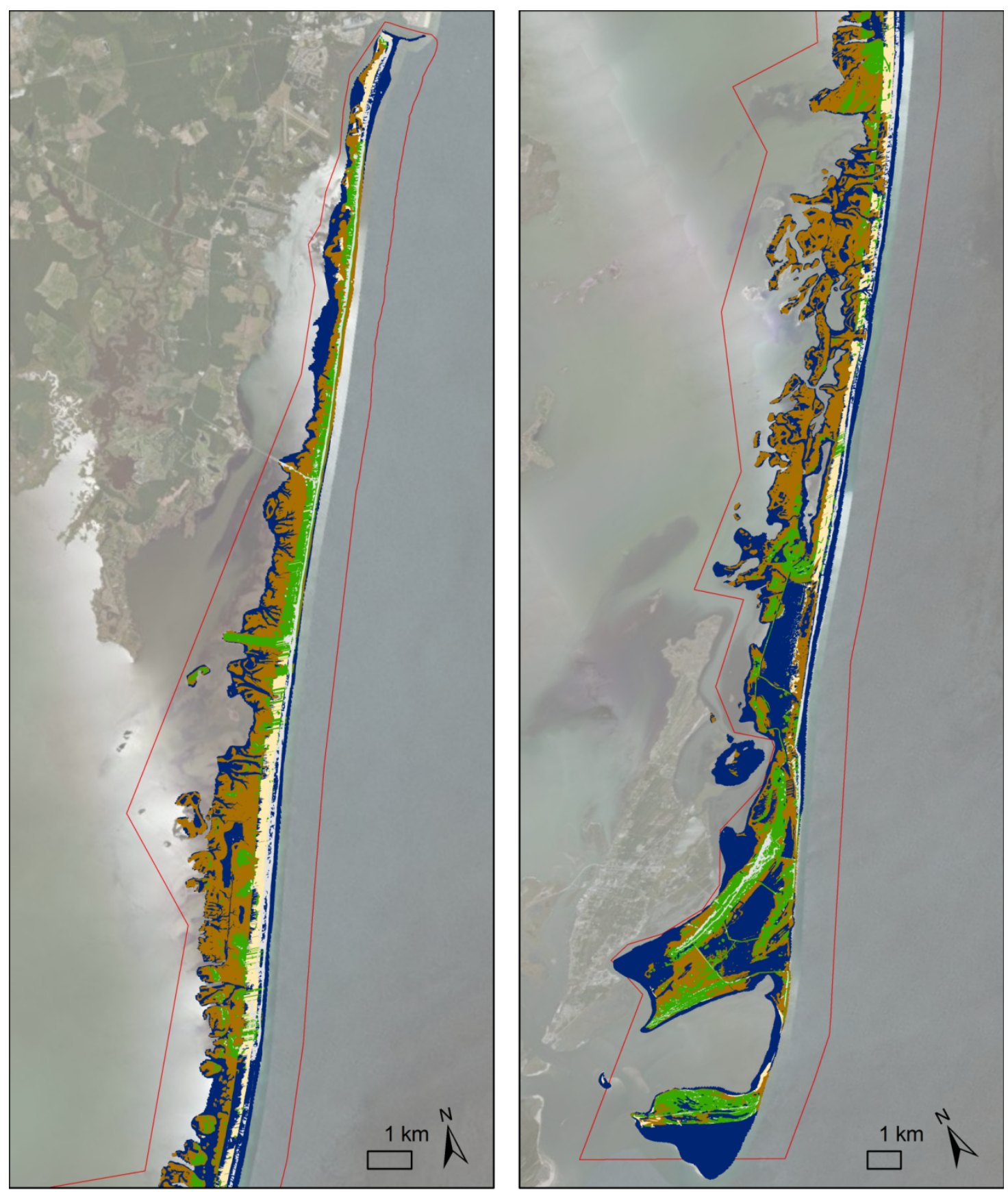

\section{Legend}
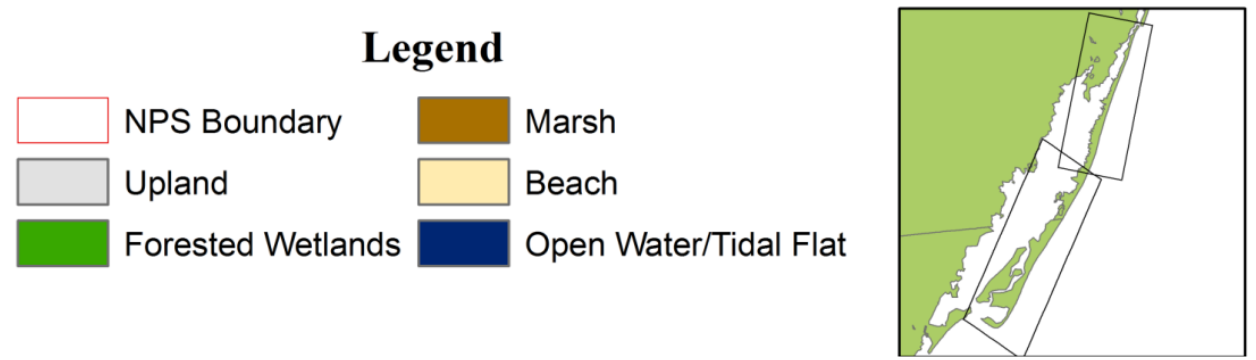
Figure A5.20 ASIS SLAMM Output: 2 m sea level rise scenario.
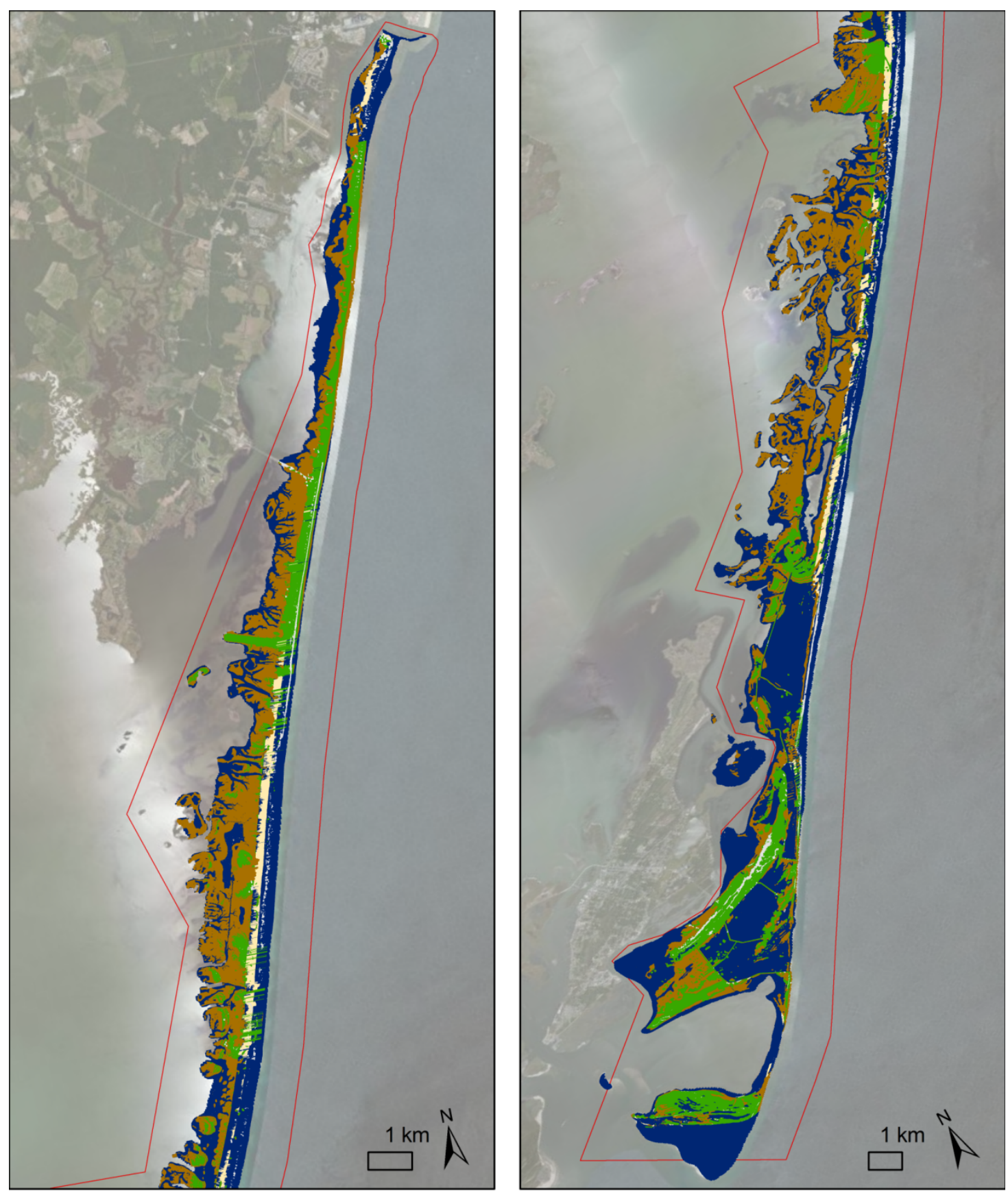

\section{Legend}
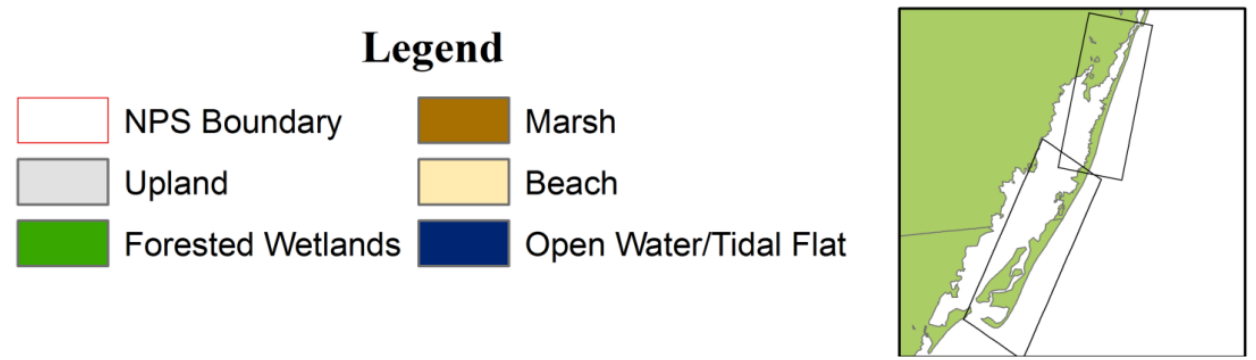


\section{APPENDIX 6}

Coastal Vulnerability Index Assessments

Figure A6.1 Relative Coastal Vulnerability for Cape Cod National Seashore, from Hammar-Klose et al. (2003).

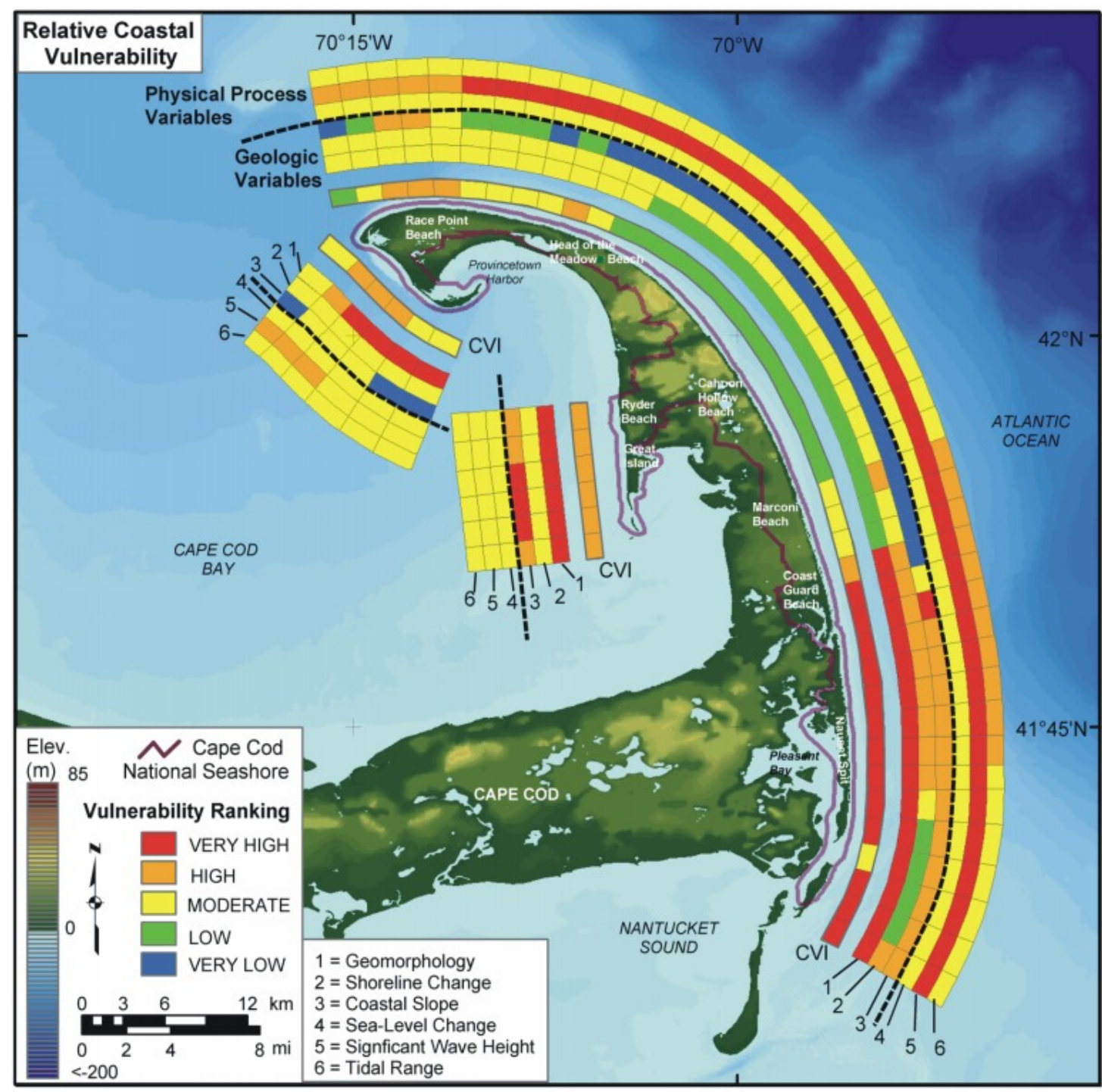


Figure A6.2 Relative Coastal Vulnerability for Assateague Island National Seashore, from Pendleton, Williams, and Thieler (2004).

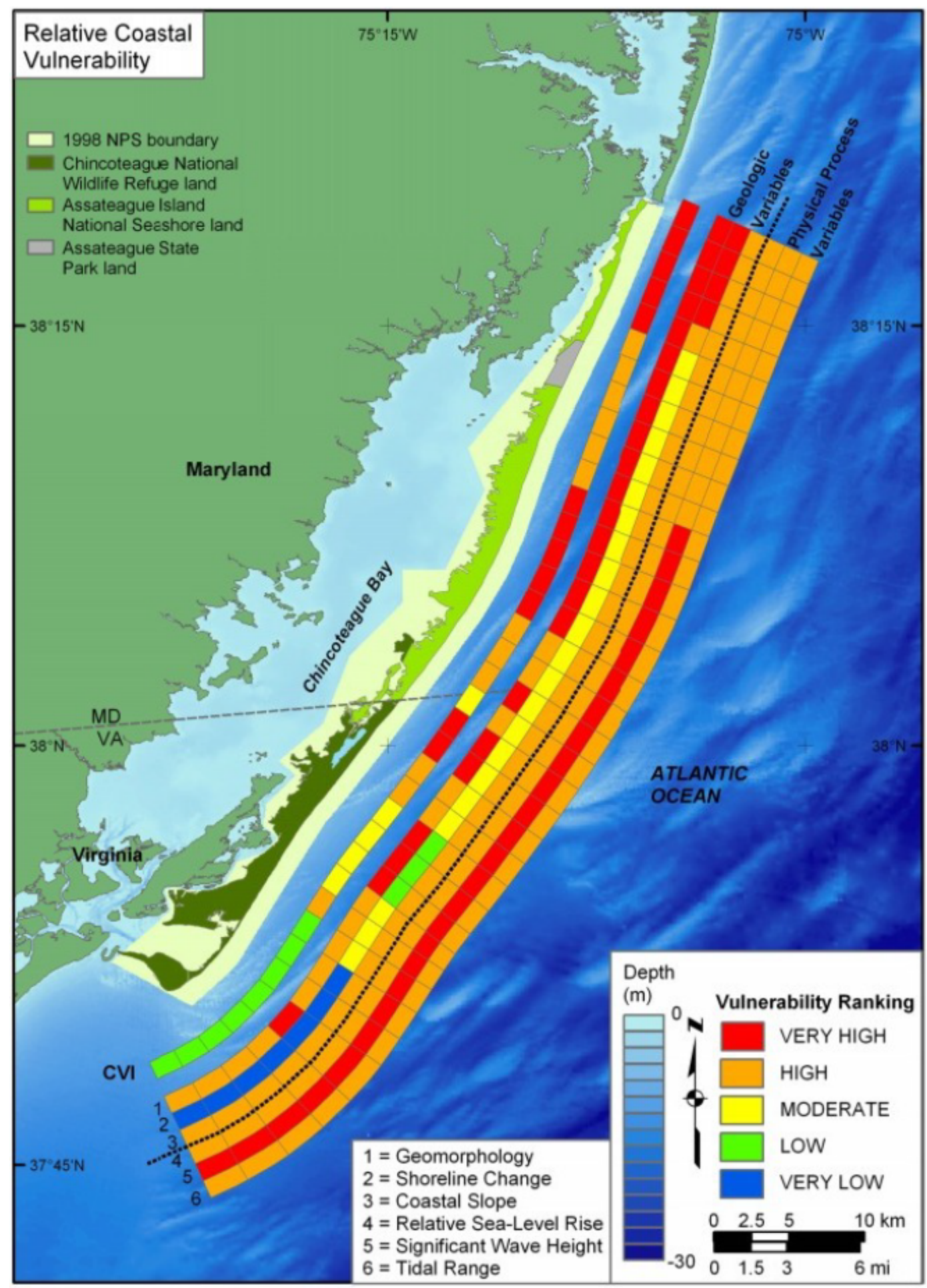

